\title{
CHEMICAL AND RADIOCHEMICAL CONSTITUENTS IN WATER FROM WELLS IN THE VICINITY OF THE NAVAL REACTORS FACILITY, IDAHO NATIONAL ENGINEERING AND ENVIRONMENTAL LABORATORY, IDAHO, 1996
}

By LeRoy L. Knobel, Roy C. Bartholomay, Betty J. Tucker, and Linda M. Williams

U.S. GEOLOGICAL SURVEY

Open-File Report 99-272

Prepared in cooperation with the U.S. DEPARTMENT OF ENERGY 


\section{U.S. DEPARTMENT OF THE INTERIOR \\ BRUCE BABBITT, Secretary}

U.S. GEOLOGICAL SURVEY

Charles G. Groat, Director

Any use of trade, product, or firm names in this publication is for descriptive purposes only and does not constitute endorsement by the U.S. Government.

U.S. Geological Survey

INEEL, MS 1160

P.O. Box 2230

Idaho Falls, ID 83403
U.S. Geological Survey

Information Services

Box 25286, Federal Center

Denver, CO 80225 


\section{DISCLAIMER}

This report was prepared as an account of work sponsored by an agency of the United States Government. Neither the United States Government nor any agency thereof, nor any of their employees, make any warranty, express or implied, or assumes any legal liability or responsibility for the accuracy, completeness, or usefulness of any information, apparatus, product, or process disclosed, or represents that its use would not infringe privately owned rights. Reference herein to any specific commercial product, process, or service by trade name, trademark, manufacturer, or otherwise does not necessarily constitute or imply its endorsement, recommendation, or favoring by the United States Government or any agency thereof. The views and opinions of authors expressed herein do not necessarily state or reflect those of the United States Government or any agency thereof. 


\section{DISCLAIMER}

Portions of this document may be illegible in electronic image products. Images are produced from the best available original document. 


\section{CONTENTS}

Abstract 1

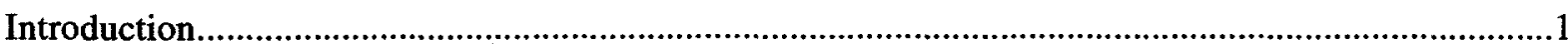

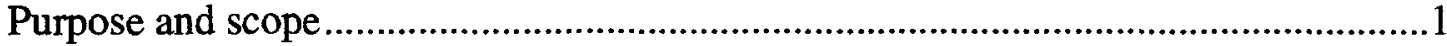

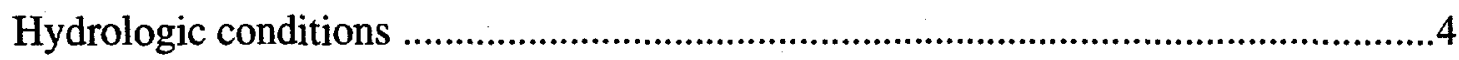

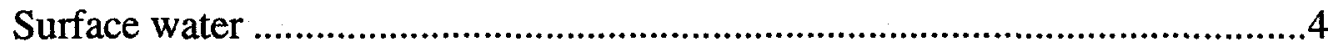

Ground water ......................................................................................

Guidelines for interpreting results of radiochemical analyses ...................................5

Guidelines for interpreting results of inorganic and organic analyses.......................

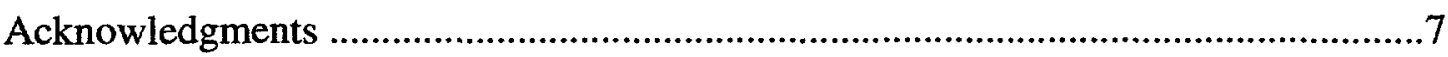

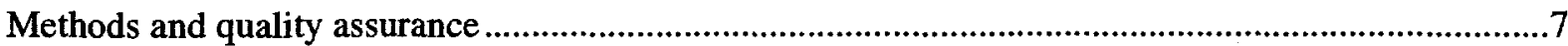

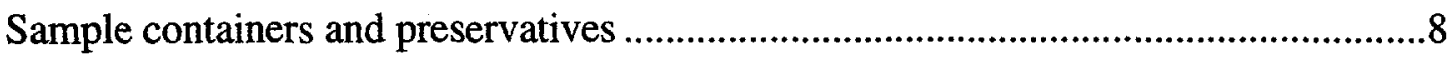

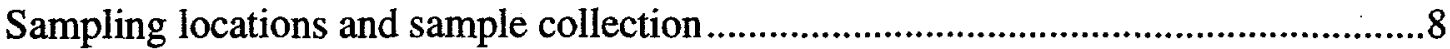

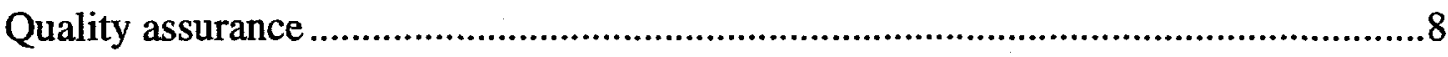

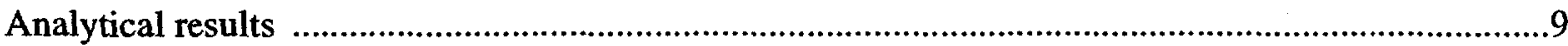

Dissolved anions and total recoverable cations ...................................................... 10

Total recoverable trace elements and dissolved beryllium and thallium....................10

Dissolved and total recoverable nutrients ............................................................ 10

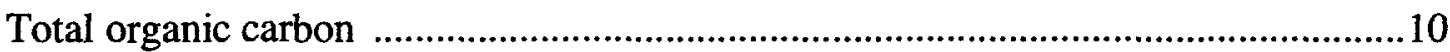

Gross alpha- and gross beta-particle radioactivity ................................................. 10

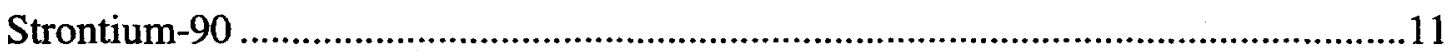

Tritium

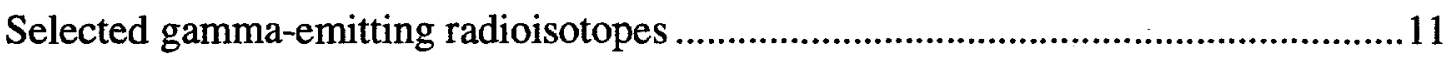

Regulatory volatile and base/neutral organic compounds ....................................12

Regulatory volatile organic compounds ...............................................12

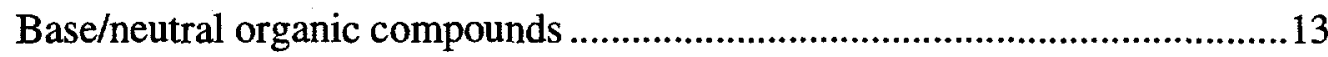

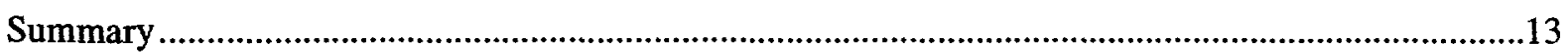

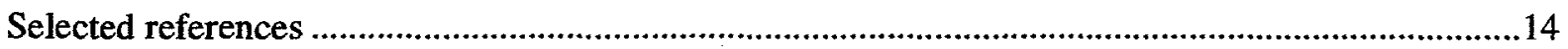

Figures 1-2. Maps showing:

\section{FIGURES}

1. Location of the Idaho National Engineering and Environmental Laboratory, Naval Reactors Facility, and other selected facilities

2. Location of wells, Naval Reactors Facility and vicinity, Idaho National Engineering and Environmental Laboratory

3. Graphs showing water levels in two wells near the Naval Reactors Facility, 1975-98 


\section{TABLES}

Table 1. Containers and preservatives used for water samples, Naval Reactors Facility and vicinity

2. Results of field measurements for alkalinity, $\mathrm{pH}$, specific conductance, and temperature of water, Naval Reactors Facility and vicinity

3. Concentrations of dissolved anions and total recoverable cations in water, Naval Reactors Facility and vicinity

4. Concentrations of selected total recoverable trace elements and dissolved beryllium and thallium in water, Naval Reactors Facility and vicinity

5. Concentrations of dissolved and total nutrients, and total organic carbon in water, Naval Reactors Facility and vicinity...

6. Concentrations of gross alpha-particle radioactivity, gross beta-particle radioactivity, strontium-90, and tritium in water, Naval Reactors Facility and vicinity

7. Concentrations of selected isotopes from analysis by gamma spectrometry, Naval Reactors Facility and vicinity

8. Regulatory volatile organic compounds for which round-four water samples were analyzed, and measured concentrations, expected concentrations, and percent recoveries for QAS-47

9. Base/neutral organic compounds for which round-four water samples were analyzed, and measured concentrations, expected concentrations, and percent recoveries for QAS-47

10. Concentrations of regulatory volatile organic compounds and base/neutral organic compounds in water from round-four samples.

\section{CONVERSION FACTORS, VERTICAL DATUM, AND ABBREVIATED UNITS}

Multiply

foot $(\mathbf{f t})$

inch (in.)

mile (mi)

square mile $\left(\mathrm{mi}^{2}\right)$

acre-foot (acre-ft)

foot per mile $(\mathrm{ft} / \mathrm{mi})$

picocurie per liter $(\mathrm{pCi} / \mathrm{L})$
By

0.3048

25.4

1.609

2.590

1,233

.1894

.037
To obtain

meter

millimeter

kilometer

square kilometer

cubic meter

meter per kilometer becquerel per liter

For temperature, degrees Celsius $\left({ }^{\circ} \mathrm{C}\right)$ can be converted to degrees Fahrenheit $\left({ }^{\circ} \mathrm{F}\right)$ by using the equation:

${ }^{\circ} \mathrm{F}=(1.8)\left({ }^{\circ} \mathrm{C}\right)+32$.

Sea level: In this report, "sea level" refers to the National Geodetic Vertical Datum of 1929--a geodetic datum derived from a general adjustment of the first-order level nets of the United States and Canada, formerly called Sea Level Datum of 1929.

Abbreviated units used in report: $\mathrm{mg} / \mathrm{L}$ (milligram per liter); $\mu \mathrm{g} / \mathrm{L}$ (microgram per liter); $\mathrm{mL}$ (milliliter); $\mathrm{L}$ (liter); $\mu \mathrm{L}$ (microliter). 


\section{CHEMICAL AND RADIOCHEMICAL CONSTITUENTS IN WATER FROM WELLS IN THE VICINITY OF THE NAVAL REACTORS FACILITY, IDAHO NATIONAL ENGINEERING AND ENVIRONMENTAL LABORATORY, IDAHO, 1996

\author{
by LeRoy L. Knobel, Roy C. Bartholomay, Betty J. Tucker, and Linda M. Williams
}

\section{Abstract}

The U.S. Geological Survey, in response to a request from the U.S. Department of Energy's Pittsburgh Naval Reactors Office, Idaho Branch Office, sampled water from 13 wells during 1996 as part of a long-term project to monitor water quality of the Snake River Plain aquifer in the vicinity of the Naval Reactors Facility, Idaho National Engineering and Environmental Laboratory, Idaho. Water samples were analyzed for naturally occurring constituents and man-made contaminants. A total of 51 samples were collected from the 13 monitoring wells. Seven qualityassurance samples also were collected and analyzed; one was a field-blank sample, one was a spiked organic sample, one was an organic tripblank sample, and four were replicate samples. The field-blank sample contained concentrations of two inorganic constituents, one organic constituent, total organic carbon, and six radioactive constituents that were greater than the reporting levels. Concentrations of other constituents in the fieldblank sample and those in the organic trip-blank sample were less than their respective reporting levels. The 4 replicate samples and their respective primary samples generated 517 pairs of analytical results for a variety of chemical and radiochemical constituents. Of the 517 data pairs, 493 were statistically equivalent at the 95-percent confidence level; about 95 percent of the analytical results were in agreement.

\section{INTRODUCTION}

The Idaho National Engineering and Environmental Laboratory (INEEL), encompassing about $890 \mathrm{mi}^{2}$ of the eastern Snake River Plain in southeastern Idaho (fig. 1), is operated by the U.S. Department of Energy (DOE). INEEL facilities are used in the development of peacetime atomicenergy applications, nuclear safety research, defense programs, advanced energy concepts, and environmental research. At the Naval Reactors Facility (NRF) (fig. 2), one facility at the INEEL, small amounts of some constituents have been released to the environment as described in the NRF environmental summary report (Bettis Atomic Power Laboratory, 1998).

This study was conducted by the U.S. Geological Survey (USGS) in cooperation with the DOE's Pittsburgh Naval Reactors (PNR) Office, Idaho Branch Office (IBO). IBO is responsible for the NRF at the INEEL. The IBO requires information about the mobility of radionuclide- and chemicalwaste constituents in the Snake River Plain aquifer. Waste-constituent mobility is determined principally by (1) the rate and direction of ground-water flow; (2) the locations, quantities, and methods of waste disposal; (3) waste-constituent chemistry; and (4) the geochemical processes taking place in the aquifer (Orr and Cecil, 1991, p. 2).

\section{Purpose and Scope}

In 1989, the IBO of the PNR Office, DOE, requested that the USGS initiate a water-quality data-collection program in the vicinity of the NRF at the INEEL (fig. 1). The purpose of the datacollection program is to provide IBO with waterchemistry data to evaluate the effect of NRF activities on the water quality of the Snake River Plain aquifer.

Through 1995, the data-collection program consisted of three rounds of sample collection. Round one was a one-time sampling of each well for a comprehensive suite of chemical constituents that approximates those contained in the U.S. Environmental Protection Agency's (EPA) Ground-Water 


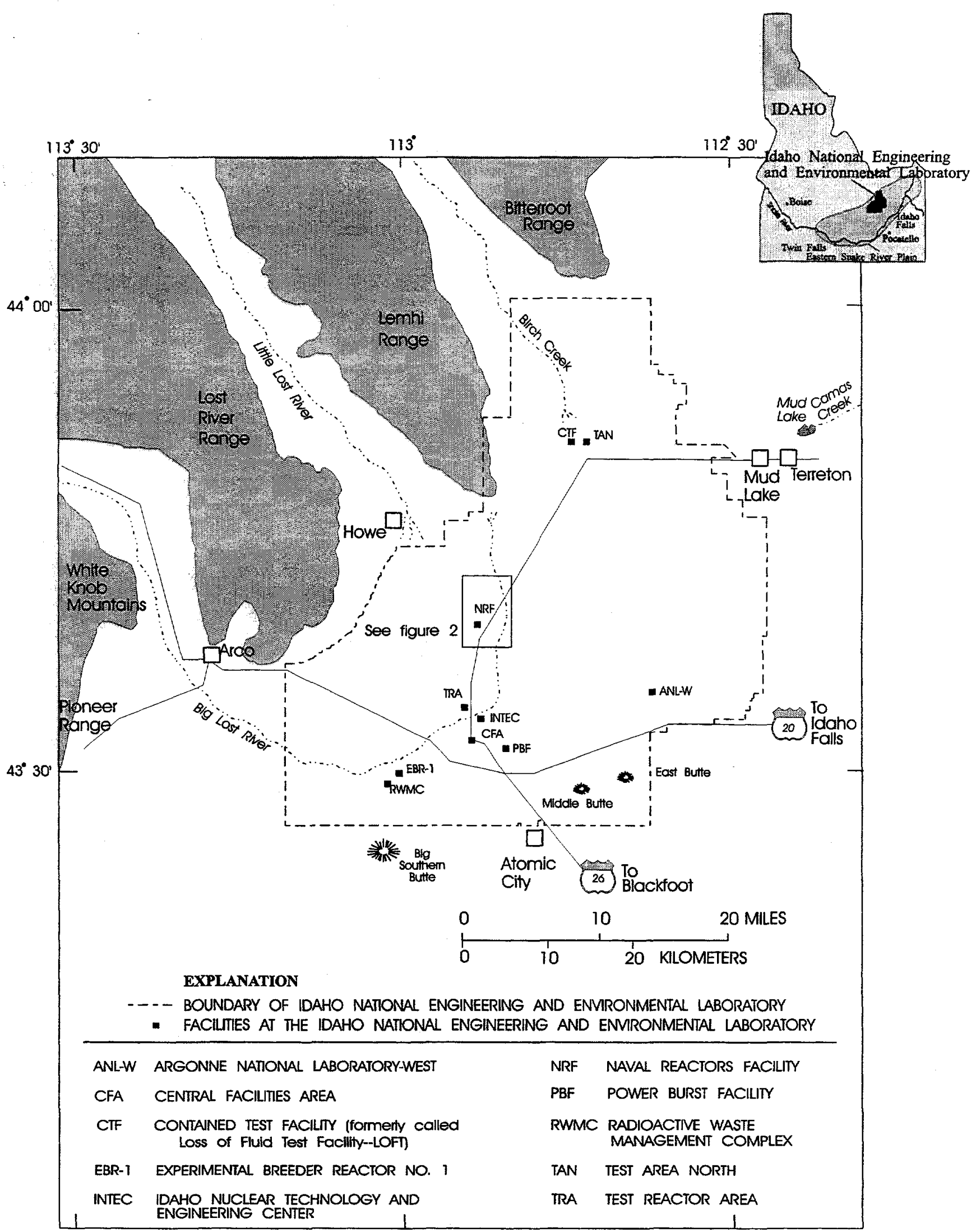

Figure 1. Location of the Idaho National Engineering and Environmental Laboratory, Naval Reactors Facility, and other selected facilities. 


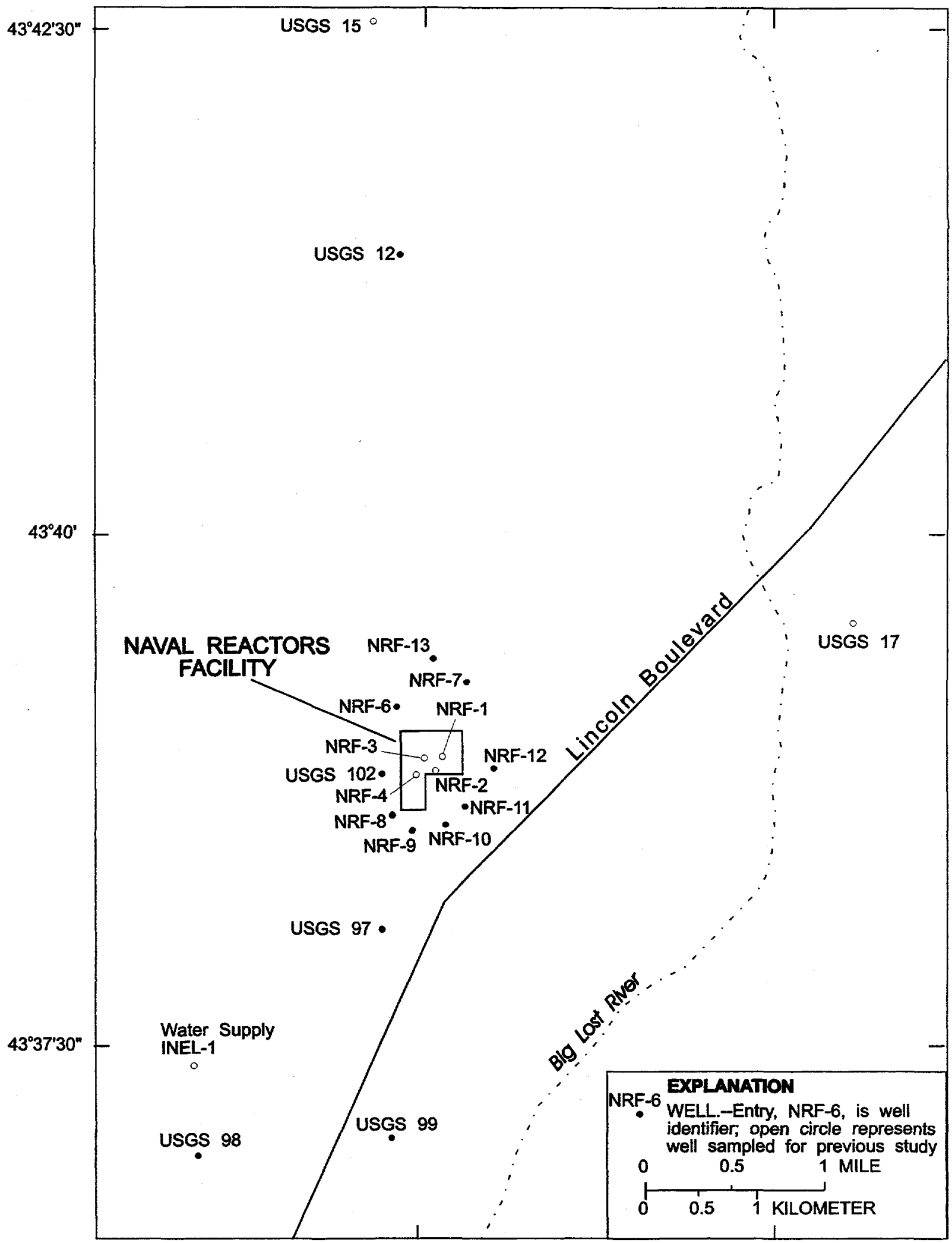

Figure 2. Location of wells, Naval Reactors Facility and vicinity, Idaho National Engineering and Environmental Laboratory. 
Monitoring List-Appendix IX (U.S. Environmental Protection Agency, 1989, p. 636-642). Round two consisted of bimonthly collection of five samples from each well that were analyzed for the chemical constituents listed in Appendix III-EPA Interim Primary Drinking Water Standards, the constituents listed as parameters establishing ground-water quality, and selected measurements used as indicators of ground-water contamination (U.S. Environmental Protection Agency, 1989, p. 660-661, 730). Additional constituents analyzed in round-two samples included copper, nickel, zinc, and extractable acid and base/neutral compounds. Round three samples were collected quarterly through 1995. Constituents analyzed in 1994 included chloride, chromium, iron, lead, mercury, nickel, nitrate as nitrogen, silver, sodium, and sulfate. Other round-three measurements were gross alpha- and gross beta-particle radioactivity, $\mathrm{pH}$, specific conductance, and total organic carbon (TOC). The round-three sampling program was expanded in 1995 to include analyses for aluminum, antimony, arsenic, barium, beryllium, cadmium, copper, manganese, selenium, thallium, tritium, and zinc. As a result of expanded laboratory procedures, rounds one through three of the sample-collection program included analyses for constituents in addition to those listed above. Results of analyses of rounds one through three samples are presented by Knobel, Bartholomay, and others (1992), Bartholomay and others (1993), Tucker and others (1995), and Bartholomay, Knobel, and Tucker (1997).

An analysis by Westinghouse Electric Corporation of the water-chemistry data collected for the NRF monitoring program during 1989-95 indicated that several changes to the program would improve the overall usefulness of the data. As a result, several older wells were eliminated from the program and replaced by monitoring wells specifically constructed to meet NRF needs and strategically placed to better intercept chemical plumes in the ground water. To differentiate between the data generated from the NRF sampling program in rounds one through three (1989-95) and subsequent data (1996), the samples collected in 1996 were designated round-four samples. Analytical results for round-four samples are included in this report. Wells sampled in rounds one through three that were eliminated from the program were the four water-supply production wells with line shaft turbine pumps (NRF-1, -2, -3, and -4) and three monitoring wells (USGS 15, USGS 17, and Water Supply INEL-1) with dedicated submersible pumps. The six newly constructed monitoring wells that were added to the sampling program in 1996 are NRF-8, $-9,-10,-11,-12$, and -13 . All of these wells and the older monitoring wells that remain in the monitoring network (NRF-6, -7, USGS $12,97-99$, and 102) have dedicated submersible pumps. Locations of the sampling sites currently being sampled and the sampling sites eliminated from the sampling program are shown in figure 2.

In addition to changing the locations of sample collection, the list of constituents for analysis in round-four samples was modified. These constituents and analytical results are presented in tables 3-10 at the back of this report. Field measurements for round-four samples included alkalinity as $\mathrm{CaCO}_{3}, \mathrm{pH}$, specific conductance, and temperature and are presented in table 2 . Round-four samples were collected quarterly at each well.

\section{Hydrologic Conditions}

The Snake River Plain aquifer is one of the most productive aquifers in the United States (U.S. Geological Survey, 1985, p. 193). The aquifer underlies the eastern Snake River Plain and consists of a thick sequence of basalts and sedimentary interbeds filling a large, arcuate, structural basin in southeastern Idaho (fig. 1).

\section{Surface Water}

The Big Lost River drains more than $1,400 \mathrm{mi}^{2}$ of mountainous area that includes parts of the Lost River Range and the Pioneer Range west of the INEEL (fig. 1). Flow in the Big Lost River infiltrates to the Snake River Plain aquifer along its channel and in sinks and playas near the river's terminus. Since 1958, excess runoff has been diverted to spreading areas in the southwestern part of the INEEL, where much of the water rapidly infiltrates to the aquifer. Other surface drainages that provide recharge to the Snake River Plain aquifer at the 
INEEL include the Little Lost River, Birch Creek, and Camas Creek (fig. 1) (Bartholomay and others, 1995, p. 18).

\section{Ground Water}

Recharge to the Snake River Plain aquifer is principally from infiltration of applied irrigation water, infiltration of streamflow, and ground-water inflow from adjoining mountain drainage basins. Some recharge may be from direct infiltration of precipitation, although the small amount of annual precipitation on the plain ( 8 in. at the INEEL), evapotranspiration, and the great depth to water (in places exceeding $900 \mathrm{ft}$ ) probably minimize this source of recharge (Orr and Cecil, 1991, p. 22-23).

Water in the Snake River Plain aquifer moves principally through fractures and interflow zones in the basalt. Most ground water moves through the upper $800 \mathrm{ft}$ of saturated rocks. Hydraulic conductivities of basalt in the upper $800 \mathrm{ft}$ of the aquifer, estimated from INEEL transmissivity data, are from 0.0086 to $5,500 \mathrm{ft} /$ day (Ackerman, 1991, p. 30 ). Estimated hydraulic conductivities in a 10,365-ft deep test hole near NRF are smaller; at depths exceeding $1,500 \mathrm{ft}$, hydraulic conductivities are from 0.002 to $0.03 \mathrm{ft} /$ day (Mann, 1986, p. 21). The effective base of the Snake River Plain aquifer at the INEEL is from about 815 to $1,710 \mathrm{ft}$ below land surface (Anderson and others, 1996, table 3, p. 23).

Depth to water in wells completed in the Snake River Plain aquifer is from about $200 \mathrm{ft}$ below land surface in the northern part of the INEEL to more than $900 \mathrm{ft}$ in the southeastern part; in the vicinity of NRF, depth to water is about $375 \mathrm{ft}$ below land surface. In 1995, the altitude of the water table was about 4,575 ft above sea level near Test Area North (fig. 1) and about 4,425 ft above sea level near the Radioactive Waste Management Complex (fig. 1); near the NRF, the water table was about $4,475 \mathrm{ft}$ above sea level. Water generally flowed southward and southwestward beneath the INEEL at an average hydraulic gradient of about $4 \mathrm{ft} / \mathrm{mi}$; however, significant local variation in flow direction is common. Beneath the NRF, water generally flowed southward. Locally, the hydraulic gradient was from about 1 to $15 \mathrm{ft} / \mathrm{mi}$. From March-May 1991 to March-May 1995, water-level changes in INEEL wells ranged from a 8.5-ft decline north of the NRF to a $2.5-\mathrm{ft}$ decline in the southern part of the INEEL; near the NRF, the water-level decline was about 6 to $8 \mathrm{ft}$. Water levels generally declined at the NRF during 1992-95 because of drought (Bartholomay, Tucker, and others, 1997, p. 20-25), but have risen since mid-1995 (fig. 3).

Ground water moves southwestward from the INEEL and eventually discharges as springs along the Snake River downstream from Twin Falls, about $100 \mathrm{mi}$ southwest of the INEEL (fig. 1). Approximately 3.7 million acre-ft of ground water was discharged in 1995 (C.E. Berenbrock, USGS, written commun., 1996).

\section{Guidelines for Interpreting Results of Radiochemical Analyses}

Concentrations of radionuclides are reported with an estimated sample standard deviation, $\mathbf{s}$, that is obtained by propagating sources of analytical uncertainty in measurements. The following guidelines for interpreting analytical results are based on an extension of a method proposed by Currie (1984).

In the analysis for a particular radionuclide, laboratory measurements are made on a target sample and a prepared blank. Instrument signals for the sample and the blank vary randomly. Therefore, it is essential to distinguish between two key aspects of the problem of detection: (1) the instrument signal for the sample must be larger than the signal observed for the blank before the decision can be made that the radionuclide was detected; and (2) an estimation must be made of the minimum radionuclide concentration that will yield a sufficiently large observed signal before the correct decision can be made for detection or nondetection of the radionuclide. The first aspect of the problem is a qualitative decision based on an observed signal and a definite criterion for detection. The second aspect of the problem is an estimation of the detection capabilities of a given measurement process.

In the laboratory, instrument signals must exceed a critical level of $1.6 \mathrm{~s}$ before the qualitative decision can be made as to whether the radionuclide was detected. At $1.6 \mathrm{~s}$, there is a 95 -percent probability that the correct conclusion-not 


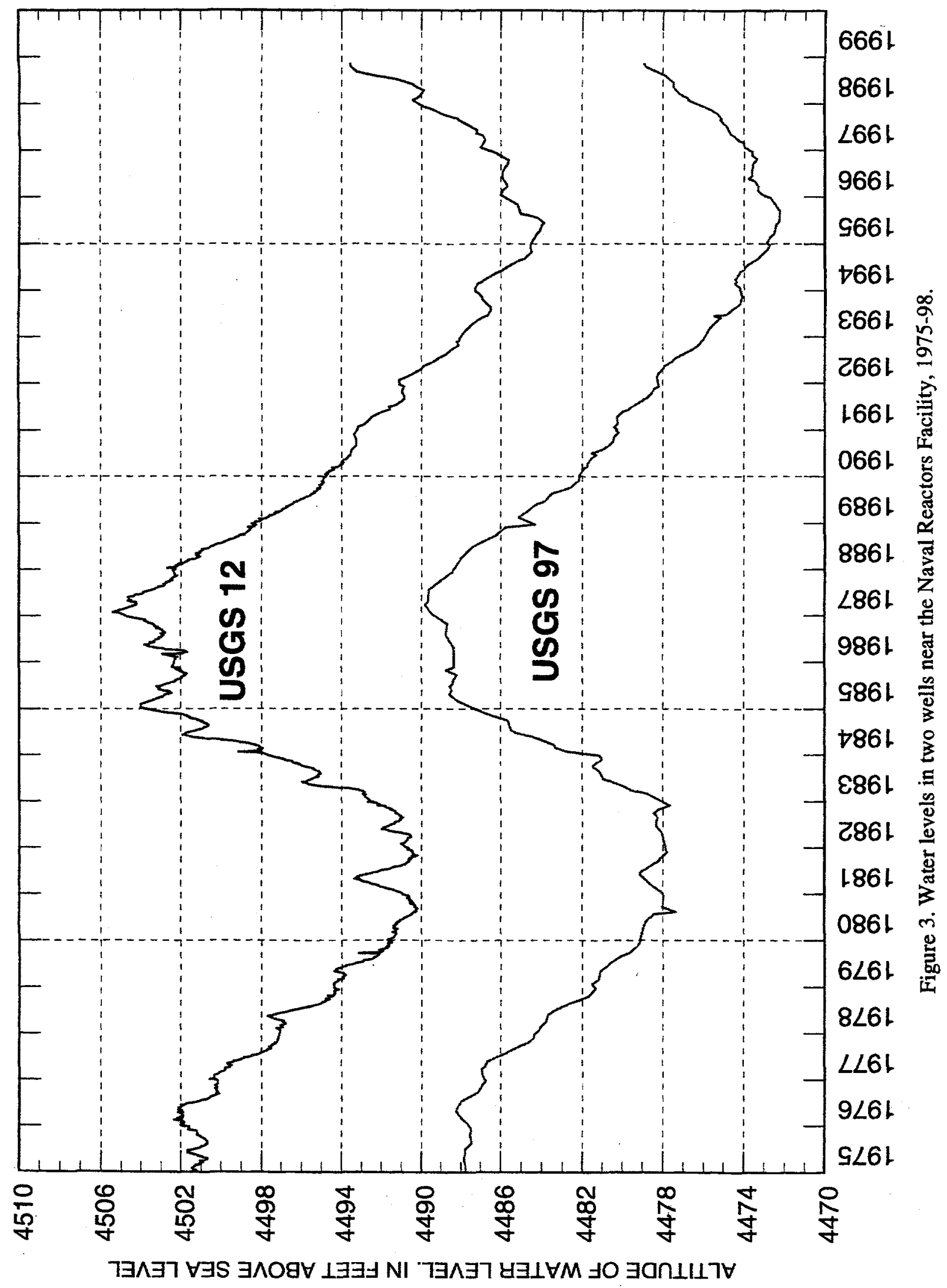


detected-will be made. Given a large number of samples, as many as 5 percent of the samples with measured concentrations larger than or equal to $1.6 \mathrm{~s}$, which were concluded as being detected, might not contain the radionuclide. These measurements are referred to as false positives and are errors of the first kind in hypothesis testing.

Once the critical level of $1.6 \mathrm{~s}$ has been defined, the minimum detectable concentration may be determined. Radionuclide concentrations that equal 3 s represent a measurement at the minimum detectable concentration. For true concentrations of $3 \mathrm{~s}$ or larger, there is a 95-percent or larger probability that the radionuclide was detected in a sample. In a large number of samples, the conclusion-not detected-will be made in 5 percent of the samples that contain true concentrations at the minimum detectable concentration of $3 \mathrm{~s}$. These measurements are referred to as false negatives and are errors of the second kind in hypothesis testing.

True radionuclide concentrations between 1.6s and $3 s$ have larger errors of the second kind. That is, there is a larger-than-5-percent probability of false negative results for samples with true concentrations between 1.6s and 3s. Although the radionuclide might have been detected, such detection may not be considered reliable; at $1.6 \mathrm{~s}$, the probability of a false negative is about 50 percent.

The critical level and minimum detectable concentration are based on counting statistics alone and do not include systematic or random errors inherent in laboratory procedures. The values $1.6 \mathrm{~s}$ and $3 \mathrm{~s}$ vary slightly with background or blank counts, with the number of gross counts for individual analyses, and for different radionuclides. In this report, radionuclide concentrations less than $3 \mathrm{~s}$ are considered to be below a "reporting level." The critical level, minimum detectable concentration, and reporting level aid the reader in the interpretation of analytical results and do not represent absolute concentrations of radioactivity which may or may not have been detected.

Many analytical results of environmental radioactivity measurements are at or near zero. If the true concentration for a given radionuclide is zero, a given set of analytical results for that radionuclide should be distributed about zero, with an equal number of negative and positive measurements. Negative analytical results occur if the radioactivity of a water sample is less than the background radioactivity or the radioactivity of the prepared blank sample in the laboratory (American Society for Testing and Materials, 1992, p. 126; Knobel, Orr, and Cecil, 1992, p. 51).

\section{Guidelines for Interpreting Results of Inorganic and Organic Analyses}

The term "reporting level" used for radiochemical analyses should not be confused with the term "minimum reporting level," which is used for inorganic and organic analyses. In this report, the term "minimum reporting level" is the smallest measured concentration of a nonradioactive constituent that may be reliably reported using a given analytical method (Timme, 1995, p. 92). Because of unpredictable matrix effects on detection limits, the laboratory reporting levels are set somewhat higher than the analytical method detection limits (Pritt and Jones, 1989).

\section{Acknowledgments}

The authors are grateful to Michael J. Smigaj of the USGS and Kelly.D. Willie, Bruce E. Olenick, and Adolfo Sierra of Westinghouse Electric Corporation for technically reviewing the manuscript.

\section{METHODS AND QUALITY ASSURANCE}

The methods used for collecting water samples generally followed the guidelines established by the USGS (Goerlitz and Brown, 1972; Stevens and others, 1975; Wood, 1981; Claassen, 1982; W.L. Bradford, USGS, written commun., 1985; Wershaw and others, 1987; Fishman and Friedman, 1989; Hardy and others, 1989; Faires, 1992; Fishman, 1993). The methods used in the field and the quality-assurance practices are described in the following sections. 


\section{Sample Containers and Preservatives}

Sample containers and preservatives differed depending on the constituent(s) for which analyses were requested. Samples analyzed by the USGS National Water Quality Laboratory (NWQL) were placed in containers and preserved in accordance with laboratory requirements specified by Timme (1995). Containers and preservatives were supplied by the NWQL and had undergone a rigorous quality-control procedure (Pritt, 1989, p. 75) to eliminate sample contamination. The containers and preservatives used for this study are listed in table 1 (all tables located at the end of report).

\section{Sampling Locations and Sample Collection}

Samples were collected from 13 monitoring wells (NRF-6, $-7,-8,-9,-10,-11,-12,-13$, USGS $12,97-99$, and 102) equipped with dedicated submersible pumps. NRF-6, -7, -13, and USGS 12 are upgradient of the NRF; USGS 102 is west of NRF; NRF-1 1 and -12 are east of NRF; and the remaining monitoring wells are downgradient of NRF (fig. 2).

Samples from dedicated submersible pumps were collected from a portable sampling apparatus which was decontaminated before sampling at each site. After collection, sample containers were sealed with laboratory film, labeled, and stored under secured conditions. Water samples were placed in ice chests, sealed, and shipped as soon as possible to the NWQL.

Conditions at the sampling site during sample collection were recorded in a field logbook and a chain-of-custody record was used to track samples from the time of collection until delivery to the NWQL. These records are available for inspection at the USGS Project Office at the INEEL. The results of field measurements for alkalinity, $\mathrm{pH}$, specific conductance, and water temperature are listed in table 2.

\section{Quality Assurance}

Internal quality control and the overall qualityassurance practices used by the NWQL are described in reports by Friedman and Erdmann
(1982), Jones (1987), and Pritt and Raese (1992). The water samples were collected by personnel assigned to the INEEL Project Office in accordance with a quality-assurance plan for quality-ofwater activities; the plan was finalized in June 1989, was revised in March 1992 and again in 1996 (Mann, 1996), and is available from the USGS Project Office at the INEEL. Comparative studies to determine agreement between analytical results for water-sample pairs by laboratories involved in the INEEL Project Office's qualityassurance program are summarized by Wegner (1989), Williams (1996), and Williams (1997). Additional quality assurance instituted for this sampling program included a field-blank sample prepared with inorganic-free and organic-free water, an organic trip-blank sample prepared by the NWQL with organic-free water; a spiked organic sample, and four replicate samples. After collection of the primary sample, a replicate sample was immediately collected. The replicate-sample analytical results were then compared with the primary-sample analytical results to evaluate the combined effects of laboratory reproducibility in analytical measurements and consistency in fieldcollection methods. Many organizations use the term "sequential replicate" in place of "replicate" sample.

On October 1, 1994, the USGS stopped preserving nutrient samples with mercuric chloride. As part of the INEEL Project Office's QualityAssurance Program, a study was conducted by Bartholomay and Williams (1996) to determine if the nutrient data collected before and after that date were comparable. NRF samples collected from October 27 to November 10,1994, were included in that study. The results indicated that nutrient data collected before and after October 1, 1994, are comparable.

Analytical results for primary and replicate water samples in this report were compared using the method described by Williams $(1996,1997)$. If standard deviations of primary- and replicate-sample results are known, it is possible to determine-within specified confidence limitswhether the results of a pair of samples are statistically equivalent. This determination can be made using an adaptation of the equation to determine 
the standard deviate or the number of standard deviations that the variable deviates from the mean (Volk, 1969, p. 55), where $\mathrm{Z}$ is the ratio of the absolute value of the difference of the two results and the pooled standard deviation (Taylor, 1987, p. 29). In that way, a comparison can be made of two analytical results on the basis of the precision-or an approximation of the precision-associated with each of the results:

$$
Z=\frac{|x-y|}{\sqrt{\left(S_{x}\right)^{2}+\left(S_{y}\right)^{2}}},
$$

where

$\mathrm{x}=$ result of the primary (routine) sample,

$y=$ result of the replicate (quality-assurance) sample,

$\mathrm{S}_{\mathrm{x}}=$ standard deviation of $\mathrm{x}$, and

$S_{y}=$ standard deviation of $y$.

If the $\mathrm{Z}$-value is less than or equal to 1.96 , the analytical results of the primary and replicate pair are considered statistically equivalent at the 95-percent confidence limit. The analytical results for radionuclides are reported by the NWQL with calculated analytical uncertainties. There is about a 67 -percent probability that the true radionuclide concentration is in a range of the reported concentration plus or minus the uncertainty. The uncertainties are expressed as one sample standard deviation (s) and equation 1 can be applied directly to the results.

Equation 1 cannot be applied directly to the results for which no standard deviations or uncertainties are reported. The NWQL does not report standard deviations with analytical results for nonradiochemical constituents; however, the USGS Branch of Quality Assurance conducts a Blind Sample Program (BSP) (Maloney and others, 1993) that allows the calculation of a most probable deviation (MPD) at any concentration for most constituents. A minimum MPD has been established for a few constituents that are generally present at small concentrations (Maloney and others, 1993, p. 4). Linear-regression equations generated from BSP data can be used to determine if the analytical results of the primary and replicate samples are statistically equivalent by calculating an
MPD for each result and substituting them for the standard deviations in equation 1 (Williams, 1996, 1997).

Organic constituents and laboratory specific conductance were not included in the BSP. Therefore, for organic carbon, standard deviations were calculated from the relative standard deviations (RSD) for dissolved organic carbon (DOC) reported by Wershaw and others (1987, p. 14-15). Wershaw and others $(1987$, p. 16) estimated that the RSD values for TOC are larger than those for DOC; therefore, the calculated Z-values are more conservative. Concentrations of volatile organic compounds in the replicate-sample pairs (except for one compound in one pair) were less than the laboratory reporting levels. The standard deviation of this volatile organic compound was calculated from the RSD's provided by Rose and Schroeder (1995, p. 18-23). The standard deviations for the laboratory measurements of specific conductance were calculated from the RSD's provided by Fishman and Friedman (1989, p. 463). Analytical results for organic constituents are included in tables 5 and 10.

$\mathrm{Z}$-values for replicate pairs of all constituents were calculated using equation 1 and are presented in the data tables. If analytical results of the pair were not statistically equivalent, an " $N$ " in parenthesis is listed next to the $\mathrm{Z}$-value. If the results of both samples of the replicate pair were less than the reporting level, the results were assumed to be equivalent and the $\mathrm{Z}$-value is reported as zero. Analytical results for the quality-assurance samples will be discussed, along with similar data, in subsequent sections of this report.

\section{ANALYTICAL RESULTS}

During the period beginning in January 1996 and ending in September 1996, quarterly water samples were collected for round four of the NRF sampling program (table 2). All wells were sampled four times except NRF-10, which was not sampled in January 1996 because the pump was inoperable. Because of a shipping delay during the September sampling round, temperature-sensitive constituents in water from wells NRF-6, $-8,-9,-10$, $-11,-12,-13$, and USGS 102 (table 2) had to be 
resampled. Quality-assurance samples included a spiked organic sample (QAS-47), an organic tripblank sample (QAS-48), a field-blank sample (QAS-52), and 4 replicate samples: NRF-8 (QAS46), NRF-10 (QAS-50), NRF-11 (QAS-49), and NRF-13 (QAS-51). QAS-47 also included a bottle of organic-free water for determination of TOC.

\section{Dissolved Anions and Total Recoverable Cations}

Water samples were analyzed for concentrations of dissolved chloride and sulfate, and concentrations of total recoverable calcium, magnesium, potassium, and sodium (table 3 ).

All concentrations in the field-blank sample (QAS-52) were less than the respective laboratory reporting levels, except the concentration of calcium, which was $2.9 \mathrm{mg} / \mathrm{L}$. All 24 replicate-sample concentrations listed in table 3 were statistically equivalent to their primary-sample concentrations.

\section{Total Recoverable Trace Elements and Dissolved Beryllium and Thallium}

Water samples collected in 1996 were analyzed for concentrations of total recoverable aluminum, antimony, arsenic, barium, cadmium, chromium, copper, iron, lead, manganese, mercury, nickel, selenium, silver, and zinc, and for concentrations of dissolved beryllium and thallium (table 4).

The concentrations of all constituents in the field-blank sample (QAS-52), except that of manganese, were less than the minimum reporting levels. Of 68 replicate-sample concentrations (table 4), 63 were statistically equivalent to their primary-sample concentrations. The statistical equivalence of the antimony concentrations in QAS-51 $(<1 \mu \mathrm{g} / \mathrm{L})$ and the primary sample NRF-13 $(1 \mu \mathrm{g} / \mathrm{L})$ was uncertain. The concentration of aluminum in QAS-50 $(440 \mu \mathrm{g} / \mathrm{L})$ was not statistically equivalent to the concentration in the primary sample, NRF-10 $(520 \mu \mathrm{g} / \mathrm{L})$. The iron concentrations in three replicate samples were not statistically equivalent to the iron concentrations in their respective primary samples: QAS-50
$(640 \mu \mathrm{g} / \mathrm{L})$ and NRF-10 $(770 \mu \mathrm{g} / \mathrm{L}) ; \mathrm{QAS}-49(60$

$\mu \mathrm{g} / \mathrm{L})$ and NRF-11 $(100 \mu \mathrm{g} / \mathrm{L})$; and QAS-51 (5,400

$\mu \mathrm{g} / \mathrm{L})$ and NRF-13 (3,100 $\mu \mathrm{g} / \mathrm{L})$.

\section{Dissolved and Total Recoverable Nutrients}

Filtered water samples were analyzed for concentrations of nitrite as nitrogen, and nitrite plus nitrate as nitrogen (table 5). Unfiltered water samples were analyzed for total concentrations of ammonia plus organic nitrogen as nitrogen, and phosphorus as phosphorus (table 5).

Concentrations of all constituents in the fieldblank sample (QAS-52) were less than the laboratory reporting levels. Fifteen of the 16 replicatesample concentrations of nitrogen and phosphorus compounds listed in table 5 were statistically equivalent to their primary-sample concentrations. The total phosphorus as phosphorus concentration in QAS-49 $(<0.01 \mathrm{mg} / \mathrm{L})$ was not statistically equivalent to the concentration in primary sample NRF-11 (0.04 mg/L).

\section{Total Organic Carbon}

Water samples were analyzed for concentrations of TOC (table 5). The concentration of TOC in the blank total organic carbon sample (QAS-47) was $0.1 \mathrm{mg} / \mathrm{L}$ and, in the field-blank sample (QAS-52), was $0.2 \mathrm{mg} / \mathrm{L}$. The laboratory reporting level was $0.1 \mathrm{mg} / \mathrm{L}$. The concentration of TOC in one replicate sample of the four listed in table 5 was statistically equivalent to the primarysample concentration. The concentrations of TOC in QAS-46 (3.4 mg/L), QAS-50 (1.0 mg/L), and QAS-51 (3.9 mg/L) were not statistically equivalent to the concentrations in their respective primary water samples: NRF-8 $(0.3 \mathrm{mg} / \mathrm{L}), \mathrm{NRF}-10$ (1.7 mg/L), and NRF-13 (0.2 mg/L).

\section{Gross Alpha- and Gross Beta-Particle Radioactivity}

Water samples were analyzed for concentrations of dissolved gross alpha- and gross betaparticle radioactivity by the NWQL using a residue procedure. Concentrations of radioactive constituents greater than or equal to three times the $1 \mathrm{~s}$ 
uncertainty are considered to be above the reporting level in this report. All analytical measurements are listed in table 6 . For a more detailed discussion of reporting levels for radioactive constituents and measurements, see the section of this report titled "Guidelines for Interpreting Results of Radiochemical Analyses."

Gross alpha-particle radioactivity--Gross alpha-particle radioactivity is a measure of the total radioactivity given off as alpha particles during the radioactive decay process. For convenience, laboratories report the radioactivity as if it all were given off by one radionuclide. In this report, concentrations are reported two ways: as natural uranium in micrograms per liter and as thorium230 in picocuries per liter; however, the NWQL discontinued reporting gross alpha as natural uranium before the June 1996 sample round, and these data are not available for June and September 1996. Concentrations of dissolved gross alpha-particle radioactivity are listed in table 6 .

In the field-blank sample (QAS-52), the concentration of gross alpha-particle radioactivity as thorium-230 $(-0.132 \pm 0.085 \mathrm{pCi} / \mathrm{L})$ was less than the reporting level. All of the six replicate-sample concentrations listed in table 6 were statistically equivalent to their primary-sample concentrations.

Gross beta-particle radioactivity.-Gross betaparticle radioactivity is a measure of the total radioactivity given off as beta particles during the radioactive decay process. For convenience, laboratories report the radioactivity as if it all were given off by one radionuclide or a chemically similar pair of radionuclides in equilibrium. In this report, concentrations are reported in two ways: as strontium-90 in equilibrium with yttrium-90 $\left(\mathrm{Sr}^{90} / \mathrm{Y}^{90}\right)$ in picocuries per liter; and as cesium137 in picocuries per liter; however, the NWQL discontinued reporting gross beta as $\mathrm{Sr}^{90} / \mathrm{Y}^{90}$ before the June 1996 sample round, and these data are not available for June and September 1996. Concentrations of dissolved gross beta-particle radioactivity are listed in table 6 .

In the field-blank sample (QAS-52), the concentration of gross beta-particle radioactivity as cesium-137 $(0.695 \pm 0.276 \mathrm{pCi} / \mathrm{L})$ was less than the reporting level. Five of the six replicate-sample concentrations listed in table 6 were statistically equivalent to their primary-sample concentrations. The concentration as $\mathrm{Sr}^{90} / \mathrm{Y}^{90}$ in QAS-49

$(5.87 \pm 0.88 \mathrm{pCi} / \mathrm{L})$ was not statistically equivalent to the concentration in the primary sample NRF-11 $(3.82 \pm 0.84 \mathrm{pCi} / \mathrm{L})$.

\section{Strontium-90}

Water samples were analyzed for strontium-90 by chemical separation and beta counting (table 6). The concentration of strontium-90 in the fieldblank sample (QAS-52) was less than the reporting level $(0.292 \pm 0.172 \mathrm{pCi} / \mathrm{L})$. All of the four replicate-sample concentrations listed in table 6 were statistically equivalent to their primary-sample concentrations.

\section{Tritium}

Water samples were analyzed for tritium by liquid scintillation (table 6). The concentration of tritium in the field-blank sample (QAS-52) was $76.8 \pm 12.8 \mathrm{pCi} / \mathrm{L}$. All of the four replicate-sample concentrations listed in table 6 were statistically equivalent to their primary-sample concentrations.

\section{Selected Gamma-emitting Radioisotopes}

Water samples were analyzed by gamma spectrometry for actinium-228, bismuth-214, cesium134 and -137 , chromium- 51 , cobalt- 60 , lead-212 and -214 , potassium- 40 , radium-223, $-224,-226$, and -228 , ruthenium-106, thallium- 208 , thorium$228,-232$, and -234 , uranium-234, -235 , and -238 , and zinc-65 (table 7). The field-blank sample (QAS-52) contained concentrations of bismuth$214(0.845 \pm 0.215 \mathrm{pCi} / \mathrm{L})$, potassium-40 (14.1 \pm 1.7 $\mathrm{pCi} / \mathrm{L})$, radium-226 $(0.845 \pm 0.215 \mathrm{pCi} / \mathrm{L})$, thallium-208 $(0.396 \pm 0.105 \mathrm{pCi} / \mathrm{L})$, and thorium-228 $(1.54 \pm 0.495 \mathrm{pCi} / \mathrm{L})$ that were greater than their reporting levels. Concentrations of the other radioisotopes in QAS-52 were less than their respective reporting levels. Of 89 replicate-sample concentrations (table 7), 75 were statistically equivalent to their primary sample concentrations. Concentrations were not reported for either the replicate or the primary sample for 6 of these 75 sample pairs. Because gamma spectrometry records the energy 
released as a result of gamma photon interactions and assigns the various energy releases to specific radionuclides by means of multi-channel analysis (American Society for Testing and Materials, 1998), the lack of a value implies that there was insufficient energy for quantification. As a result, the Z-value for the six data pairs without reported concentrations was set to zero and the pairs were assumed to be statistically equivalent. The concentration of bismuth-214 in QAS-49 (-0.189 \pm 0.215 $\mathrm{pCi} / \mathrm{L}$ ) was not statistically equivalent to the concentration in the primary sample, NRF-11 $(0.579 \pm 0.21 \mathrm{pCi} / \mathrm{L})$. Concentrations in QAS -46 of lead-212 $(0.175 \pm 0.27 \mathrm{pCi} / \mathrm{L})$ and of lead-214 $(1.02 \pm 0.195 \mathrm{pCi} / \mathrm{L})$ were not statistically equivalent to the concentrations in the respective primary sample (NRF-8) of lead-212 (0.919 $\pm 0.145 \mathrm{pCi} / \mathrm{L})$ and lead-214 $(0.336 \pm 0.175 \mathrm{pCi} / \mathrm{L})$. The potassium40 concentrations in three replicate samples were not statistically equivalent to the potassium- 40 concentrations in their respective primary samples:

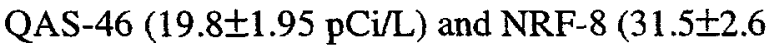
$\mathrm{pCi} / \mathrm{L})$, QAS-50 (3.56 $\pm 2.8 \mathrm{pCi} / \mathrm{L})$ and $\mathrm{NRF}-10$ $(27.8 \pm 2.25 \mathrm{pCi} / \mathrm{L})$, and QAS-51 (11.0 $2.70 \mathrm{pCi} / \mathrm{L})$ and NRF-13 (58.2 $\pm 3.75 \mathrm{pCi} / \mathrm{L})$. The concentration of radium-226 in QAS-49 $(-0.189 \pm 0.215 \mathrm{pCi} / \mathrm{L})$ was not statistically equivalent to the concentration in the primary sample NRF-11 $(0.579 \pm 0.210$ $\mathrm{pCi} / \mathrm{L}$ ), and the concentration of strontium- 85 in QAS-51 $(0 \pm 0 \mathrm{pCi} / \mathrm{L})$ was not statistically equivalent to the concentration in the primary sample NRF-13 $(0.641 \pm 0.170 \mathrm{pCi} / \mathrm{L})$. The concentration of thallium-208 in QAS-51 $(0.138 \pm 0.105 \mathrm{pCi} / \mathrm{L})$ was not statistically equivalent to the concentration in the primary sample NRF-13 $(0.540 \pm 0.105$ $\mathrm{pCi} / L)$, and the concentration of thorium-234 in QAS-51 (54.9 $\pm 17.5 \mathrm{pCi} / \mathrm{L})$ was not statistically equivalent to the concentration in the primary sample NRF-13 (-16.5 $\pm 18.5 \mathrm{pCi} / \mathrm{L})$. The concentration of uranium-234 in QAS-50 (1.30 $\pm 0.335 \mathrm{pCi} / \mathrm{L})$ was not statistically equivalent to the concentration in the primary sample NRF-10 $(-0.332 \pm 0.325$ $\mathrm{pCi} / \mathrm{L}$ ), and the concentration of uranium-238 in QAS-46 $(1.02 \pm 0.195 \mathrm{pCi} / \mathrm{L})$ was not statistically equivalent to the concentration in the primary sample NRF-8 $(0.336 \pm 0.175 \mathrm{pCi} / \mathrm{L})$. The zinc- 65 concentrations in two replicate samples were not statistically equivalent to the zinc- 65 concentrations in their respective primary samples:
QAS-50 (0.0920 $\pm 0.235 \mathrm{pCi} / \mathrm{L})$ and NRF-10 $(-0.825 \pm 0.240 \mathrm{pCi} / \mathrm{L})$, and QAS-51 (-0.645 \pm 0.235 $\mathrm{pCi} / \mathrm{L})$ and $\mathrm{NRF}-13(0.664 \pm 0.195 \mathrm{pCi} / \mathrm{L})$.

\section{Regulatory Volatile and Base/Neutral Organic Compounds}

Water samples collected in 1996 were analyzed for 30 regulatory volatile organic compounds (table 8) and 43 base/neutral organic compounds (table 9). Spiked organic samples (QAS-47) were prepared and submitted to the NWQL, along with a laboratory-prepared organic trip blank (QAS-48), for analysis of the compounds listed in tables 8 and 9.

\section{Regulatory Volatile Organic Compounds}

The 30 regulatory volatile organic compounds that were analyzed for in the round-four water samples are listed in table 8 along with their respective laboratory reporting levels. Most samples did not contain regulatory volatile organic compounds; however, NRF- 6 contained chloroform and tetrachloroethene in all four sampling events (table 10) and NRF 13 contained methylene chloride in all four sampling events (table 10). The replicate sample (QAS-51) and the primary sample (NRF-13) collected on June 13, 1998, both contained 0.5 $\mu \mathrm{g} / \mathrm{L}$ of methylene chloride. Concentrations of all compounds in the trip-blank (QAS-47) were less than their respective reporting levels. All 120 replicate and primary sample pairs were statistically equivalent.

Table 8 contains information about the qualityassurance sample (QAS-47) spiked for the regulatory volatile organic compounds. The NWQL provided a solution with known concentrations of 13 organic compounds (table 8 ) for use in spiking matrix samples. Three $40-\mathrm{mL}$ vials were prepared by adding $0.1 \mathrm{~mL}$ of the spiking solution to 39.9 $\mathrm{mL}$ of certified organic-free water. These vials then were submitted to the NWQL for analyses. The results of the analysis, the expected concentrations in the spiked sample, and the calculated percent recoveries are listed in table 8 . The expected concentrations were calculated from the known concentrations in the spiking solution and the dilution volume. The vinyl chloride ( 20 per- 
cent) and 1,1-dichloroethene (41 percent) recovery values were outside the range considered normal (60-140 percent) by the NWQL. The remaining percent-recovery values were within the expected range. Methylene chloride (which was not contained in the spiking solution) was measured in the spiked sample at a concentration of $1.3 \mu \mathrm{g} / \mathrm{L}$.

\section{Base/Neutral Organic Compounds}

The 43 base/neutral organic compounds that were analyzed for in the round-four water samples are listed in table 9 along with their respective laboratory reporting levels. Most samples did not contain base/neutral organic compounds; however, the field-blank sample (QAS-52) contained $6 \mu \mathrm{g} / \mathrm{L}$ of bis (2-ethylhexyl) phthalate; the June 1996 sample from USGS 99 contained $6 \mu \mathrm{g} / \mathrm{L}$ of diethyl phthalate; and the June 1996 sample from USGS 102 contained $57 \mu \mathrm{g} / \mathrm{L}$ of Di-n-butylphthalate (table 10). All 172 replicate and primary sample pairs were statistically equivalent.

Table 9 contains information about the qualityassurance sample (QAS-47) that was spiked for base/neutral organic compounds. The NWQL provided a solution with known concentrations of 41 base/neutral organic compounds (table 9) for use in spiking matrix samples. A 1-L sample was prepared by the addition of $100 \mu \mathrm{L}$ of spike solution to certified organic-free water. The 1-L sample then was submitted to the NWQL for analysis. The results of the analysis, the expected concentrations in the spiked sample, and the calculated percent recoveries are listed in table 9 . The expected concentrations were calculated from the known concentrations in the spiking solution and the dilution volume. Several recovery values were outside the range considered normal (60-140 percent) by the NWQL: butylbenzylphthalate (58 percent), diethyl phthalate ( 25 percent), dimethyl phthalate ( 9 percent), hexachlorocyclopentadiene (46 percent), isophorone (17 percent), n-nitrosodi-n-propylamine ( 47 percent), n-nitrosodiphenylamine (203 percent), n-nitrosodimethylamine (29 percent), and di-n-bultylphthalate ( 59 percent). The remaining 32 recovery values were within the expected range. Benzo (a) pyrene and 4-bromophenylphenylether (which were not contained in the spiking solution) were measured in the spiked sample at concentrations of $20 \mu \mathrm{g} / \mathrm{L}$ and $16 \mu \mathrm{g} / \mathrm{L}$, respectively.

\section{SUMMARY}

The USGS, in response to a request from the U.S. Department of Energy's Pittsburgh Naval Reactors Office, Idaho Branch Office, sampled 13 wells during 1996 as part of a long-term project to monitor water quality of the Snake River Plain aquifer in the vicinity of the NRF, INEEL, Idaho. Water samples were collected and analyzed for naturally occurring constituents and man-made contaminants. A total of 51 samples were collected from 13 monitoring wells with dedicated submersible pumps. Seven quality-assurance samples also were collected and analyzed: one field-blank sample, one spiked-organic sample, one organic tripblank sample, and four replicate samples. The field-blank sample contained concentrations of 10 constituents that were greater than the laboratory reporting levels: two inorganic constituents (calcium and manganese), one organic constituent (bis (2-ethylhexyl) phthalate), total organic carbon, and six radionuclides (bismuth-214, potassium-40, radium-226, thallium-208, thorium-228, and tritium). Concentrations of other constituents in the field-blank sample and the organic trip-blank sample were less than the respective reporting levels. The 4 replicate samples and their respective primary samples generated 517 pairs of analytical results for a variety of chemical and radiochemical constituents. Of the 517 pairs of analytical results, 493 were statistically equivalent at the 95 -percent confidence level; about 95 percent of the analytical results were in agreement. The 23 data pairs that were not statistically equivalent included the following numbers and types of data pairs: 1 aluminum, 1 gross beta-particle radioactivity as $\mathrm{Sr}^{90} / \mathrm{Y}^{90}$, 3 iron, 1 total phosphorus as phosphorus, 3 TOC, and 14 gamma emitting radioisotopes. The statistical equivalence of one antimony data pair was uncertain. Percent recovery values for two of 13 regulatory volatile organic compounds and 9 of 41 base/neutral organic compounds in the spiked organic sample were outside the range considered normal ( $60-140$ percent) by the NWQL. 


\section{SELECTED REFERENCES}

Ackerman, D.J., 1991, Transmissivity of the Snake River Plain aquifer at the Idaho National Engineering Laboratory, Idaho: U.S. Geological Survey Water-Resources Investigations Report 91-4058 (DOE/ID22097), 35 p.

American Society for Testing and Materials, 1992, ASTM standards on precision and bias for various applications: Philadelphia, $\mathrm{Pa}$., American Society for Testing and Materials Publication code number (PCN) 03-511092$34,478 \mathrm{p}$.

American Society for Testing and Materials, 1998, Standard method for high-resolution gammaray spectrometry of water (D3649-91): Philadelphia, Pa., American Society of Testing and Materials 1998 Annual Book of ASTM Standards, v. 11.02, 1,048 p.

Anderson, S.R., Ackerman, D.J., Liszewski, M.J., and Freiburger, R.M., 1996, Stratigraphic data for wells at and near the Idaho National Engineering Laboratory, Idaho: U.S. Geological Survey Open-File Report 96-248 (DOE/ID-22127), 27 p., 1 diskette.

Bartholomay, R.C., Knobel, L.L., and Tucker, B.J., 1993, Chemical constituents in water from wells in the vicinity of the Naval Reactors Facility, Idaho National Engineering Laboratory, Idaho, 1990-91: U.S. Geological Survey Open-File Report 93-94 (DOE/ID22106), $70 \mathrm{p}$.

-.-1997, Chemical and radiochemical constituents in water from wells in the vicinity of the Naval Reactors Facility, Idaho National Engineering Laboratory, Idaho, 1994-95: U.S. Geological Survey Open-File Report 97-806 (DOE/ID-22143), $70 \mathrm{p}$.

Bartholomay, R.C., Orr, B.R., Liszewski, M.J., and Jensen, R.G., 1995, Hydrologic conditions and distribution of selected radiochemical and chemical constituents in water, Snake River
Plain aquifer, Idaho National Engineering Laboratory, Idaho, 1989 through 1991: U.S. Geological Survey Water-Resources Investigations Report 95-4175 (DOE/ID22123), $47 \mathrm{p}$.

Bartholomay, R.C., Tucker, B.J., Ackerman, D.J., and Liszewski, M.J., 1997, Hydrologic conditions and distribution of selected radiochemical and chemical constituents in water, Snake River Plain aquifer, Idaho National Engineering Laboratory, Idaho, 1992 through 1995: U.S. Geological Survey WaterResources Investigations Report 97-4086 (DOE/ID-22137), $57 \mathrm{p}$.

Bartholomay, R.C., and Williams, L.M., 1996, Evaluation of preservation methods for selected nutrients in ground water at the Idaho National Engineering Laboratory, Idaho: U.S. Geological Survey Water-Resources Investigations Report 96-4260 (DOE/ID22131), 16 p.

Bettis Atomic Power Laboratory Naval Reactors Facility, 1998, Remedial investigation/ feasibility study for the external industrial waste ditch, operable unit 8-07: Westinghouse Electric Corporation NRFRC-EC-1046, 26 p.

Claassen, H.C., 1982, Guidelines and techniques for obtaining water samples that accurately represent the water chemistry of an aquifer: U.S. Geological Survey Open-File Report 82-1024, 49 p.

Currie, L.A., 1984, Lower limit of detection-definition and elaboration of a proposed position for radiological effluent and environmental measurements: U.S. Nuclear Regulatory Commission NUREG/CR-4077, $139 \mathrm{p}$.

Faires, L.M., 1992, Methods of analysis by the U.S. Geological Survey National Water Quality Laboratory-determination of metals in water by inductively coupled plasma-mass spectrometry: U.S. Geological Survey Open-File Report 92-634, 28 p. 
Fishman, M.J., ed., 1993, Methods of analysis by the U.S. Geological Survey National Water Quality Laboratory-determination of inorganic and organic constituents in water and fluvial sediments: U.S. Geological Survey Open-File Report 93-125, 217 p.

Fishman, M.J., and Friedman, L.C., eds., 1989, Methods for determination of inorganic substances in water and fluvial sediments: U.S. Geological Survey Techniques of WaterResources Investigations, book 5, chap. A1, $545 \mathrm{p}$.

Friedman, L.C., and Erdmann, D.E., 1982, Quality assurance practices for the chemical and biological analyses of water and fluvial sediments: U.S. Geological Survey Techniques of Water-Resources Investigations, book 5 , chap. A6, $181 \mathrm{p}$.

Goerlitz, D.F., and Brown, Eugene, 1972, Methods for analysis of organic substances in water: U.S. Geological Survey Techniques of WaterResources Investigations, book 5, chap. A3, $40 \mathrm{p}$.

Hardy, M.A., Leahy, P.P., and Alley, W.M., 1989, Well installation and documentation, and ground-water sampling protocols for the pilot national water-quality assessment program: U.S. Geological Survey Open-File Report 89396,36 p.

Iman, R.L., and Conover, W.J., 1983, A modern approach to statistics: New York, John Wiley \& Sons, Inc., 497 p.

Jones, B.E., 1987, Quality control manual of the U.S. Geological Survey's National Water Quality Laboratory: U.S. Geological Survey Open-File Report 87-457, 17 p.

Knobel, L.L., Bartholomay, R.C., Wegner, S.J., and Edwards, D.D., 1992, Chemical constituents in water from wells in the vicinity of the Naval Reactors Facility, Idaho National Engineering Laboratory, Idaho, 1989-90: U.S. Geological Survey Open-File Report 92156 (DOE/ID-22103), $38 \mathrm{p}$.
Knobel, L.L., Orr, B.R., and Cecil, L.D., 1992 , Summary of background concentrations of selected radiochemical and chemical constituents in groundwater from the Snake River Plain aquifer, Idaho; estimated from an analysis of previously published data: Journal of the Idaho Academy of Science, v. 28, no. 1, p. 48-61.

Maloney, T.J., Ludtke, A.S., and Krizman, T.L., 1993, Quality-assurance data for routine water analysis in the laboratories of the U.S. Geological Survey for water year 1990: U.S. Geological Survey Water-Resources Investigations Report 93-4082, 145 p.

Mann, L.J., 1986, Hydraulic properties of rock units and chemical quality of water for INEL1-a 10,365-foot deep test hole drilled at the Idaho National Engineering Laboratory, Idaho: U.S. Geological Survey WaterResources Investigations Report 86-4020 (DOE/ID-22070), 23 p.

-- 1989, Tritium concentrations in flow from selected springs that discharge to the Snake River, Twin Falls-Hagerman area, Idaho: U.S. Geological Survey Water-Resources Investigations Report 89-4156 (DOE/ID22084), $20 \mathrm{p}$.

1996, Quality-assurance plan and field methods for quality-of-water activities, U.S. Geological Survey, Idaho National Engineering Laboratory, Idaho: U.S. Geological Survey Open-File Report 96-615 (DOE/ID-22132), $37 \mathrm{p}$.

Orr, B.R., and Cecil, L.D., 1991, Hydrologic conditions and distribution of selected chemical constituents in water, Snake River Plain aquifer, Idaho National Engineering Laboratory, Idaho, 1986 to 1988: U.S. Geological Survey Water-Resources Investigations Report 91-4047 (DOE/ID22096), 56 p.

Pritt, J.W., 1989, Quality assurance of sample containers and preservatives at the U.S. Geological Survey National Water Quality Laboratory, in Pederson, G.L., and Smith, M.M., compilers, U.S. Geological Survey, 
second national symposium on water quality - abstracts of the technical sessions: U.S. Geological Survey Open-File Report 89409 , p. 75 .

Pritt, Jeffrey, and Jones, B.E., eds., 1989, 1990 National Water Quality Laboratory services catalog: U.S. Geological Survey Open-File Report 89-386, unnumbered.

Pritt, Jeffrey, and Raese, J.W., eds., 1992, Quality assurance/quality control manual, National Water Quality Laboratory: U.S. Geological Survey Open-File Report 92-495, 33 p.

Rose, D.L., and Schroeder, M.P., 1995, Methods of analysis by the U.S. Geological Survey National Water Quality Laboratory-determination of volatile organic compounds in water by purge and trap capillary gas chromatography/mass spectrometry: U.S. Geological Survey OpenFile Report 94-708, 26 p.

Stevens, H.H., Jr., Ficke, J.F., and Smoot, G.F., 1975, Water temperature-influential factors, field measurement, and data presentation: U.S. Geological Survey Techniques of WaterResources Investigations, book 5, chap. D1, $65 \mathrm{p}$.

Taylor, J.K., 1987, Quality assurance of chemical measurements: Chelsea, Mich., Lewis Publishers, Inc., 328 p.

Thatcher, L.L., Janzer, V.J., and Edwards, K.W., 1977, Methods for determination of radioactive substances in water and fluvial sediments: U.S. Geological Survey Techniques of Water-Resources Investigations, book 5, chap. A5, $95 \mathrm{p}$.

Timme, P.J., 1995, National Water Quality Laboratory, 1995 services catalog: U.S. Geological Survey Open-File Report 95-352, $120 \mathrm{p}$.

Tucker, B.J., Knobel, L.L., and Bartholomay, R.C., 1995, Chemical constituents in water from wells in the vicinity of the Naval Reactors Facility, Idaho National Engineering Laboratory, Idaho, 1991-93: U.S. Geological Survey Open-File Report 95-725 (DOE/ID22125), 94 p.
U.S. Environmental Protection Agency, 1989, Protection of Environment, Code of Federal Regulations 40: Office of the Federal Register, National Archives and Records Administration, pts. 190 to 299, 1,027 p.

U.S. Geological Survey, 1985, National water summary, 1984-hydrologic events, selected water-quality trends, and ground-water resources: U.S. Geological Survey WaterSupply Paper 2275, $467 \mathrm{p}$.

Volk, William, 1969, Applied statistics for engineers ( $2 \mathrm{~d}$ ed.): New York, McGraw-Hill Book Company, 415 p.

Wegner, S.J., 1989, Selected water quality assurance data for water samples collected by the U.S. Geological Survey, Idaho National Engineering Laboratory, Idaho, 1980 to 1988: U.S. Geological Survey Water-Resources Investigations Report 89-4168 (DOE/ID22085), $91 \mathrm{p}$.

Wershaw, R.L., Fishman, M.J., Grabbe, R.R., and Lowe, L.E., 1987, Method for the determination of organic substances in water and fluvial sediments: U.S. Geological Survey Techniques of Water-Resources Investigations, book 5, chap. A3, 80 p.

Williams, L.M., 1996, Evaluation of quality assurance/quality control data collected by the U.S. Geological Survey for water-quality activities at the Idaho National Engineering Laboratory, Idaho, 1989 through 1993: U.S. Geological Survey Water-Resources Investigations Report 96-4148 (DOE/ID22129), $116 \mathrm{p}$.

1997, Evaluation of quality assurance/quality control data collected by the U.S. Geological Survey for water-quality activities at the Idaho National Engineering Laboratory, Idaho, 1994 through 1995: U.S. Geological Survey WaterResources Investigations Report 97-4058 (DOE/ID-22136), $87 \mathrm{p}$. 
Wood, W.W., 1981, Guidelines for collection and field analysis of ground-water samples for selected unstable constituents: U.S.

Geological Survey Techniques of Water-

Resources Investigations, book 1, chap. D2, 24 p. 
Table 1. Containers and preservatives used for water samples, Naval Reactors Facility and vicinity

[Analyses by U.S. Geological Survey National Water Quality Laboratory. Abbreviations: $\mathrm{mL}$, milliliter; L, liter; $\mathrm{HNO}_{3}$, nitric acid; $\mathrm{K}_{2} \mathrm{Cr}_{2} \mathrm{O}_{7}$, potassium dichromate; $\mathrm{H}_{2} \mathrm{SO}_{4}$, sulfuric acid; $\mathrm{HCl}$, hydrochloric acid; ${ }^{\circ} \mathrm{C}$, degrees Celsius. Chilled samples were shipped by overnight-delivery mail]

\begin{tabular}{|c|c|c|c|c|c|}
\hline \multirow{2}{*}{ Type of constituent } & \multicolumn{2}{|c|}{ Container } & \multicolumn{2}{|c|}{ Preservative } & \multirow{2}{*}{$\begin{array}{l}\text { Other } \\
\text { treatment }\end{array}$} \\
\hline & Type & Size & Type & Volume & \\
\hline Anions & Polyethylene & $250 \mathrm{~mL}$ & None & None & Filter \\
\hline Cations, total recoverable & $\begin{array}{l}\text { Polyethylene, } \\
\text { acid-rinsed }\end{array}$ & $250 \mathrm{~mL}$ & $\mathrm{HNO}_{3}$ & $1 \mathrm{~mL}$ & None \\
\hline $\begin{array}{l}\text { Trace elements, total } \\
\text { recoverable }\end{array}$ & $\begin{array}{l}\text { Polyethylene, } \\
\text { acid-rinsed }\end{array}$ & $250 \mathrm{~mL}$ & $\mathrm{HNO}_{3}$ & $1 \mathrm{~mL}$ & None \\
\hline Trace elements, dissolved & $\begin{array}{l}\text { Polyethylene, } \\
\text { acid-rinsed }\end{array}$ & $250 \mathrm{~mL}$ & $\mathrm{HNO}_{3}$ & $1 \mathrm{~mL}$ & Filter \\
\hline Mercury, total recoverable & $\begin{array}{l}\text { Glass, } \\
\text { acid-rinsed }\end{array}$ & $250 \mathrm{~mL}$ & $\mathrm{~K}_{2} \mathrm{Cr}_{2} \mathrm{O}_{7} / \mathrm{HNO}_{3}$ & $10 \mathrm{~mL}$ & None \\
\hline Nutrients, dissolved & $\begin{array}{l}\text { Polyethylene, } \\
\text { brown }\end{array}$ & $125 \mathrm{~mL}$ & $\mathrm{H}_{2} \mathrm{SO}_{4}$ & $1 \mathrm{~mL}$ & Filter, chill $4^{\circ} \mathrm{C}$ \\
\hline Nutrients, dissolved & $\begin{array}{l}\text { Polyethylene, } \\
\text { brown }\end{array}$ & $125 \mathrm{~mL}$ & None & None & Filter, chill $4^{\circ} \mathrm{C}$ \\
\hline Nutrients, total recoverable & $\begin{array}{l}\text { Polyethylene, } \\
\text { brown }\end{array}$ & $125 \mathrm{~mL}$ & $\mathrm{H}_{2} \mathrm{SO}_{4}$ & $1 \mathrm{~mL}$ & Chill $4^{\circ} \mathrm{C}$ \\
\hline Specific conductance & Polyethylene & $125 \mathrm{~mL}$ & None & None & None \\
\hline Total organic carbon & Glass, baked & $125 \mathrm{~mL}$ & None & None & Chill $4^{\circ} \mathrm{C}$ \\
\hline Volatile organic compounds & Glass, baked & $40 \mathrm{~mL}$ & $\mathrm{HCl}$ & 4 drops & Chill $4^{\circ} \mathrm{C}$ \\
\hline $\begin{array}{l}\text { Base/neutral organic } \\
\text { compounds }\end{array}$ & Glass, baked & $1 \mathrm{~L}$ & None & None & Chill $4^{\circ} \mathrm{C}$ \\
\hline $\begin{array}{l}\text { Gamma-emitting } \\
\text { radioisotopes }\end{array}$ & $\begin{array}{l}\text { Polyethylene, } \\
\text { acid-rinsed }\end{array}$ & $1 \mathrm{~L}$ & $\mathrm{HNO}_{3}$ & $4 \mathrm{~mL}$ & Filter \\
\hline $\begin{array}{l}\text { Gross alpha- and beta-particle } \\
\text { radioactivity }\end{array}$ & $\begin{array}{l}\text { Polyethylene, } \\
\text { acid-rinsed }\end{array}$ & $1 L$ & $\mathrm{HNO}_{3}$ & $4 \mathrm{~mL}$ & Filter \\
\hline Strontium-90 & $\begin{array}{l}\text { Polyethylene, } \\
\text { acid-rinsed }\end{array}$ & $1 \mathrm{~L}$ & $\mathrm{HNO}_{3}$ & $4 \mathrm{~mL}$ & Filter \\
\hline Tritium & Polyethylene & $125 \mathrm{~mL}$ & None & None & None \\
\hline
\end{tabular}


Table 2. Results of field measurements for alkalinity, pH, specific conductance, and temperature of water, Naval Reactors Facility and vicinity

[Sample identifier: see figure 2 for well locations. Measurements for QAS-47 were made prior to the addition of the spiking solution. Date sampled: ( $\mathrm{m} / \mathrm{d} / \mathrm{y})$, month/day/year. Alkalinity: $\mathrm{CaCO}_{3}$, calcium carbonate. Units: $\mathrm{pH}$, negative base-10 logarithm of hydrogen ion activity in moles per liter; specific conductance, microsiemens per centimeter at $25^{\circ} \mathrm{C}$ (degrees Celsius); temperature, ${ }^{\circ} \mathrm{C}$. Abbreviations: lab, laboratory; NM, not measured; NC, not collected. Remarks: Field blank, indicates sample was inorganic- and organic-free water from the U.S. Geological Survey National Water Quality Laboratory. QAS indicates qualityassurance sample (values for field measurements for each pair of primary and replicate samples are the same measurement); Z-values associated with QA replicates for lab specific conductance were calculated using equation 1]

\begin{tabular}{|c|c|c|c|c|c|c|c|c|}
\hline $\begin{array}{l}\text { Sample } \\
\text { identifier }\end{array}$ & $\begin{array}{l}\text { Date sampled } \\
\qquad(\mathrm{m} / \mathrm{d} / \mathrm{y})\end{array}$ & Time & $\begin{array}{l}\text { Alkalinity } \\
\text { as } \mathrm{CaCO}_{3}\end{array}$ & $\mathrm{pH}$ & $\begin{array}{c}\text { Specific } \\
\text { conductance (field) }\end{array}$ & $\begin{array}{l}\text { Temper- } \\
\text { ature }\end{array}$ & $\begin{array}{c}\text { Specific } \\
\text { conductance (lab) }\end{array}$ & Remarks \\
\hline QAS-47 & $1 / 23 / 96$ & 0900 & NM & 9.8 & 20 & 10.5 & $\mathrm{NC}$ & Spiked organic sample \\
\hline \multirow[t]{5}{*}{ NRF-6 } & $1 / 16 / 96$ & 1615 & 155 & 7.4 & 1,447 & 11.5 & 1,420 & \\
\hline & $3 / 19 / 96$ & 1305 & 166 & 7.9 & 1,478 & 11.5 & 1,450 & \\
\hline & $6 / 10 / 96$ & 1600 & 171 & 7.9 & 1,454 & 11.5 & 1,420 & \\
\hline & $9 / 5 / 96$ & 0920 & 173 & 7.8 & 1,480 & 11.5 & 1,460 & \\
\hline & $9 / 10 / 96$ & 1330 & NM & 8.0 & 1,472 & 12.0 & $\mathrm{NC}$ & Resample \\
\hline \multirow[t]{5}{*}{ NRF-7 } & $1 / 16 / 96$ & 1145 & 94 & 8.0 & 248 & 14.5 & 247 & \\
\hline & $3 / 19 / 96$ & 1140 & 103 & 8.2 & 249 & 14.5 & 246 & \\
\hline & $6 / 10 / 96$ & 1145 & 108 & 8.3 & 250 & 15.0 & 249 & \\
\hline & $9 / 3 / 96$ & 1120 & 106 & 8.5 & 236 & 17.0 & 237 & \\
\hline & $9 / 3 / 96$ & 1130 & NM & NM & $\mathrm{NM}$ & NM & 2 & QAS-52, field blank \\
\hline \multirow[t]{4}{*}{ NRF-8 } & $1 / 17 / 96$ & 1505 & 209 & 7.6 & 585 & 11.0 & 561 & \\
\hline & $1 / 17 / 96$ & 1600 & 209 & 7.6 & 585 & 11.0 & 584 & $\begin{array}{l}\text { QAS-46, replicate } \\
(\mathrm{Z} \text {-value }=0.93)\end{array}$ \\
\hline & $3 / 25 / 96$ & 1330 & 217 & 7.9 & 591 & 11.5 & 573 & \\
\hline & $6 / 11 / 96$ & 1410 & 210 & 8.0 & 594 & 12.0 & 584 & \\
\hline
\end{tabular}


Table 2. Results of field measurements for alkalinity, pH, specific conductance, and temperature of water, Naval Reactors Facility and vicinity-Continued

\begin{tabular}{|c|c|c|c|c|c|c|c|c|}
\hline $\begin{array}{l}\text { Sample } \\
\text { identifier }\end{array}$ & $\begin{array}{l}\text { Date sampled } \\
(\mathrm{m} / \mathrm{d} / \mathrm{y})\end{array}$ & Time & $\begin{array}{l}\text { Alkalinity } \\
\text { as } \mathrm{CaCO}_{3}\end{array}$ & $\mathrm{pH}$ & $\begin{array}{c}\text { Specific } \\
\text { conductance (field) }\end{array}$ & $\begin{array}{l}\text { Temper- } \\
\text { ature }\end{array}$ & $\begin{array}{c}\text { Specific } \\
\text { conductance (lab) }\end{array}$ & Remarks \\
\hline \multirow[t]{2}{*}{ NRF-8 - Cont. } & $9 / 4 / 96$ & 1315 & 214 & 8.0 & 595 & 11.5 & 586 & \\
\hline & $9 / 10 / 96$ & 0900 & NM & 8.0 & 596 & 11.5 & $\mathrm{NC}$ & Resample \\
\hline \multirow[t]{5}{*}{ NRF-9 } & $1 / 18 / 96$ & 1300 & 201 & 7.4 & 630 & 11.0 & 632 & \\
\hline & $3 / 26 / 96$ & 0930 & 201 & 7.8 & 630 & 11.5 & 620 & \\
\hline & $6 / 11 / 96$ & 1530 & 203 & $8.0^{\prime}$ & 648 & 12.0 & 635 & \\
\hline & $9 / 4 / 96$ & 1425 & 205 & 8.1 & 647 & 11.5 & 635 & \\
\hline & $9 / 10 / 96$ & 0945 & NM & 8.0 & 649 & 11.5 & $\mathrm{NC}$ & Resample \\
\hline \multirow[t]{5}{*}{ NRF-10 } & $5 / 8 / 96$ & 1045 & 203 & 8.0 & 615 & 11.5 & 598 & \\
\hline & $6 / 12 / 96$ & 0915 & 201 & 8.0 & 615 & 12.0 & 607 & \\
\hline & $6 / 12 / 96$ & 1030 & 201 & 8.0 & 615 & 12.0 & 608 & $\begin{array}{l}\text { QAS-50, replicate } \\
(\mathrm{Z} \text {-value }=0.04)\end{array}$ \\
\hline & $9 / 4 / 96$ & 1540 & 200 & 8.1 & 608 & 11.5 & 605 & \\
\hline & $9 / 10 / 96$ & 1035 & NM & 8.0 & 615 & 11.5 & $\mathrm{NC}$ & Resample \\
\hline \multirow[t]{6}{*}{ NRF-11 } & $1 / 18 / 96$ & 1540 & 194 & 7.7 & 615 & 11.0 & 619 & \\
\hline & $3 / 25 / 96$ & 1510 & 201 & 7.9 & 629 & 11.5 & 609 & \\
\hline & $3 / 25 / 96$ & 1545 & 201 & 7.9 & 629 & 11.5 & 613 & $\begin{array}{l}\text { QAS-49, replicate } \\
(\mathrm{Z} \text {-value }=0.16)\end{array}$ \\
\hline & $6 / 12 / 96$ & 1100 & 205 & 8.0 & 631 & 12.0 & 619 & \\
\hline & $9 / 5 / 96$ & 1200 & 198 & 8.0 & 631 & 11.5 & 624 & \\
\hline & $9 / 10 / 96$ & 1130 & NM & 8.0 & 627 & 11.5 & $\mathrm{NC}$ & Resample \\
\hline
\end{tabular}


Table 2. Results of field measurements for alkalinity, pH, specific conductance, and temperature of water, Naval Reactors Facility and vicinity-Continued

\begin{tabular}{|c|c|c|c|c|c|c|c|c|}
\hline $\begin{array}{l}\text { Sample } \\
\text { identifier }\end{array}$ & $\begin{array}{l}\text { Date sampled } \\
\qquad(\mathrm{m} / \mathrm{d} / \mathrm{y})\end{array}$ & Time & $\begin{array}{l}\text { Alkalinity } \\
\text { as } \mathrm{CaCO}_{3}\end{array}$ & $\mathrm{pH}$ & $\begin{array}{c}\text { Specific } \\
\text { conductance (field) }\end{array}$ & $\begin{array}{l}\text { Temper- } \\
\text { ature }\end{array}$ & $\begin{array}{c}\text { Specific } \\
\text { conductance (lab) }\end{array}$ & Remarks \\
\hline \multirow[t]{5}{*}{ NRF-12 } & $1 / 22 / 96$ & 1120 & 197 & 7.8 & 684 & 11.5 & 673 & \\
\hline & $3 / 20 / 96$ & 1545 & 196 & 7.9 & 682 & 11.5 & 657 & \\
\hline & $6 / 12 / 96$ & 1255 & 197 & 8.0 & 682 & 12.0 & 671 & \\
\hline & $9 / 5 / 96$ & 1045 & 201 & 8.0 & 684 & 11.5 & 671 & \\
\hline & $9 / 10 / 96$ & 1240 & $\mathrm{NM}$ & 8.0 & 684 & 12.0 & NC & Resample \\
\hline \multirow[t]{6}{*}{ NRF-13 } & $1 / 22 / 96$ & 1520 & 92 & 8.2 & 496 & 15.0 & 480 & \\
\hline & $3 / 20 / 96$ & 1410 & 112 & 8.4 & 489 & 18.5 & 469 & \\
\hline & $6 / 13 / 96$ & 1245 & 88 & 8.4 & 532 & 18.5 & 530 & \\
\hline & $6 / 13 / 96$ & 1330 & 88 & 8.4 & 532 & 18.5 & 526 & $\begin{array}{l}\text { QAS-51, replicate } \\
(\mathrm{Z} \text {-value }=0.18)\end{array}$ \\
\hline & $9 / 5 / 96$ & 1550 & 93 & 8.5 & 540 & 16.5 & 534 & \\
\hline & $9 / 11 / 96$ & 0950 & $\mathrm{NM}$ & 8.4 & 532 & 17.5 & $\mathrm{NC}$ & Resample \\
\hline \multirow[t]{4}{*}{ USGS 12} & $1 / 16 / 96$ & 1430 & 194 & 7.5 & 606 & 11.5 & 600 & \\
\hline & $3 / 21 / 96$ & 1040 & 214 & 7.7 & 597 & 11.5 & 587 & \\
\hline & $6 / 10 / 96$ & 1440 & 215 & 7.9 & 607 & 11.5 & 594 & \\
\hline & $9 / 3 / 96$ & 1540 & 214 & 8.0 & 595 & 11.5 & 587 & \\
\hline \multirow[t]{4}{*}{ USGS 97} & $1 / 17 / 96$ & 1255 & 212 & 7.4 & 593 & 11.0 & 591 & \\
\hline & $3 / 25 / 96$ & 1140 & 222 & 7.8 & 596 & 11.0 & 580 & \\
\hline & $6 / 11 / 96$ & 1045 & 217 & 8.0 & 600 & 11.5 & 590 & \\
\hline & $9 / 4 / 96$ & 1035 & 219 & 8.0 & 602 & 11.5 & 591 & \\
\hline
\end{tabular}


Table 2. Results of field measurements for alkalinity, pH, specific conductance, and temperature of water, Naval Reactors Facility and vicinity-Continued

\begin{tabular}{|c|c|c|c|c|c|c|c|c|}
\hline $\begin{array}{l}\text { Sample } \\
\text { identifier }\end{array}$ & $\begin{array}{l}\text { Date sampled } \\
\qquad(\mathrm{m} / \mathrm{d} / \mathrm{y})\end{array}$ & Time & $\begin{array}{l}\text { Alkalinity } \\
\text { as } \mathrm{CaCO}_{3}\end{array}$ & $\mathrm{pH}$ & $\begin{array}{c}\text { Specific } \\
\text { conductance (field) }\end{array}$ & $\begin{array}{l}\text { Temper- } \\
\text { ature }\end{array}$ & $\begin{array}{c}\text { Specific } \\
\text { conductance (lab) }\end{array}$ & Remarks \\
\hline \multirow[t]{4}{*}{ USGS 98} & $1 / 17 / 96$ & 0905 & 174 & 7.8 & 431 & 12.0 & 430 & \\
\hline & $3 / 21 / 96$ & 1345 & 161 & 7.9 & 430 & 12.5 & 425 & \\
\hline & $6 / 11 / 96$ & 0810 & 181 & 8.0 & 440 & 12.0 & 435 & \\
\hline & 9/4/96 & 0800 & 180 & 7.9 & 440 & 12.0 & 434 & \\
\hline \multirow[t]{4}{*}{ USGS 99} & $1 / 17 / 96$ & 1055 & 207 & 7.5 & 525 & 11.0 & 525 & \\
\hline & $3 / 25 / 96$ & 0945 & 213 & 7.7 & 532 & 11.5 & 513 & \\
\hline & $6 / 11 / 96$ & 0930 & 212 & 8.0 & 532 & 11.5 & 526 & \\
\hline & 9/4/96 & 0920 & 221 & 8.0 & 537 & 11.5 & 528 & \\
\hline \multirow[t]{5}{*}{ USGS 102} & $1 / 18 / 96$ & 1050 & 210 & 7.5 & 578 & 11.0 & 584 & \\
\hline & 3/19/96 & 1435 & 218 & 7.9 & 592 & 11.5 & 571 & \\
\hline & $6 / 11 / 96$ & 1250 & 217 & 8.0 & 593 & 11.5 & 586 & \\
\hline & 9/4/96 & 1200 & 218 & 8.0 & 596 & 11.5 & 586 & \\
\hline & 9/10/96 & 0815 & NM & 7.9 & 598 & 11.5 & $\mathrm{NC}$ & Resample \\
\hline
\end{tabular}


Table 3. Concentrations of dissolved anions and total recoverable cations in water, Naval Reactors Facility and vicinity

[Analyses were performed by the U.S. Geological Survey National Water Quality Laboratory. Analytical results in milligrams per liter. Sample identifier: see figure 2 for well locations. Date sampled: (m/d/y), month/day/year. QAS indicates quality-assurance sample; 52 is a field-blank sample; others are replicates. Z-values associated with QA replicates were calculated using equation 1 . Symbol: <, concentration is less than the specified laboratory reporting level]

\begin{tabular}{|c|c|c|c|c|c|c|c|}
\hline Sample identifier & $\begin{array}{c}\text { Date sampled } \\
(\mathrm{m} / \mathrm{d} / \mathrm{y})\end{array}$ & $\begin{array}{l}\text { Calcium } \\
\text { (total) }\end{array}$ & $\begin{array}{l}\text { Chloride } \\
\text { (dissolved) }\end{array}$ & $\begin{array}{l}\text { Magnesium } \\
\quad \text { (total) }\end{array}$ & $\begin{array}{l}\text { Potassium } \\
\text { (total) }\end{array}$ & $\begin{array}{l}\text { Sodium } \\
\text { (total) }\end{array}$ & $\begin{array}{c}\text { Sulfate } \\
\text { (dissolved) }\end{array}$ \\
\hline QAS-52 & $9 / 3 / 96$ & 2.9 & $<0.1$ & $<0.1$ & $<0.1$ & $<0.1$ & $<0.1$ \\
\hline \multirow[t]{4}{*}{ NRF-6 } & $1 / 16 / 96$ & 130 & 220 & 37 & 4.4 & 100 & 220 \\
\hline & $3 / 19 / 96$ & 52 & 230 & 35 & 4.4 & 110 & 210 \\
\hline & $6 / 10 / 96$ & 120 & 230 & 36 & 4.7 & 100 & 210 \\
\hline & $9 / 5 / 96$ & 130 & 240 & 35 & 4.4 & 110 & 200 \\
\hline \multirow[t]{4}{*}{ NRF-7 } & $1 / 16 / 96$ & 25 & 4.6 & 8.8 & 2.9 & 9.1 & 13 \\
\hline & $3 / 19 / 96$ & 25 & 5 & 8.9 & 2.8 & 8.9 & 14 \\
\hline & $6 / 10 / 96$ & 25 & 5.1 & 9.3 & 2.8 & 8.7 & 13 \\
\hline & $9 / 3 / 96$ & 24 & 5.2 & 9 & 2.8 & 9.5 & 14 \\
\hline NRF-8 & $1 / 17 / 97$ & 69 & 34 & 24 & 2.1 & 15 & 34 \\
\hline QAS-46 & $1 / 17 / 96$ & 69 & 34 & 24 & 2.1 & 14 & 34 \\
\hline$Z$-value & $1 / 17 / 96$ & 0 & 0 & 0 & 0 & 1.65 & 0 \\
\hline \multirow[t]{3}{*}{ NRF-8 } & $3 / 25 / 96$ & 74 & 37 & 23 & 2.2 & 14 & 35 \\
\hline & $6 / 11 / 96$ & 67 & 35 & 24 & 2.4 & 13 & 34 \\
\hline & $9 / 4 / 96$ & 71 & 35 & 24 & 2.2 & 14 & 35 \\
\hline \multirow[t]{2}{*}{ NRF-9 } & $1 / 18 / 96$ & 74 & 45 & 25 & 2.3 & 17 & 49 \\
\hline & $3 / 26 / 96$ & 79 & 46 & 23 & 2.4 & 17 & 50 \\
\hline
\end{tabular}


Table 3. Concentrations of dissolved anions and total recoverable cations in water, Naval Reactors Facility and vicinityContinued

\begin{tabular}{|c|c|c|c|c|c|c|c|}
\hline Sample identifier & $\begin{array}{l}\text { Date sampled } \\
(\mathrm{m} / \mathrm{d} / \mathrm{y})\end{array}$ & $\begin{array}{l}\text { Calcium } \\
\text { (total) }\end{array}$ & $\begin{array}{l}\text { Chloride } \\
\text { (dissolved) }\end{array}$ & $\begin{array}{l}\text { Magnesium } \\
\quad \text { (total) }\end{array}$ & $\begin{array}{l}\text { Potassium } \\
\text { (total) }\end{array}$ & $\begin{array}{l}\text { Sodium } \\
\text { (total) }\end{array}$ & $\begin{array}{c}\text { Sulfate } \\
\text { (dissolved) }\end{array}$ \\
\hline \multirow[t]{2}{*}{ NRF-9 - Cont. } & $6 / 11 / 96$ & 68 & 48 & 25 & 2.4 & 16 & 48 \\
\hline & 9/4/96 & 73 & 48 & 24 & 2.4 & 17 & 49 \\
\hline \multirow[t]{2}{*}{ NRF-10 } & $5 / 8 / 96$ & 84 & 42 & 25 & 2.3 & 15 & 44 \\
\hline & $6 / 12 / 96$ & 70 & 44 & 24 & 2.5 & 14 & 42 \\
\hline QAS-50 & $6 / 12 / 96$ & 69 & 43 & 24 & 2.3 & 15 & 43 \\
\hline Z-value & $6 / 12 / 96$ & .19 & .42 & 0 & .75 & 1.65 & .32 \\
\hline NRF-10 & $9 / 4 / 96$ & 72 & 43 & 25 & 2.4 & 16 & 44 \\
\hline \multirow[t]{2}{*}{ NRF-11 } & $1 / 18 / 96$ & 70 & 43 & 24 & 2.6 & 19 & 47 \\
\hline & $3 / 25 / 96$ & 78 & 46 & 23 & 2.5 & 18 & 49 \\
\hline QAS-49 & $3 / 25 / 96$ & 85 & 46 & 24 & 2.5 & 19 & 49 \\
\hline Z-value & $3 / 25 / 96$ & 1.12 & 0 & .68 & 0 & 1.16 & 0 \\
\hline \multirow[t]{2}{*}{ NRF-11 } & $6 / 12 / 96$ & 65 & 45 & 25 & 2.4 & 18 & 47 \\
\hline & $9 / 5 / 96$ & 72 & 44 & 23 & 2.8 & 19 & 50 \\
\hline \multirow[t]{4}{*}{ NRF-12 } & $1 / 22 / 96$ & 75 & 58 & 26 & 2.7 & 22 & 59 \\
\hline & $3 / 20 / 96$ & 80 & 57 & 23 & 2.3 & 22 & 60 \\
\hline & $6 / 12 / 96$ & 69 & 59 & 26 & 2.5 & 21 & 58 \\
\hline & $9 / 5 / 96$ & 72 & 59 & 25 & 2.5 & 21 & 59 \\
\hline \multirow[t]{3}{*}{ NRF-13 } & $1 / 22 / 96$ & 63 & 58 & 18 & 5.0 & 12 & 67 \\
\hline & $3 / 20 / 96$ & 71 & 57 & 18 & 4.8 & 10 & 69 \\
\hline & $6 / 13 / 96$ & 70 & 61 & 22 & 4.6 & 11 & 69 \\
\hline
\end{tabular}


Table 3. Concentrations of dissolved anions and total recoverable cations in water, Naval Reactors Facility and vicinityContinued

\begin{tabular}{lccccccc}
\hline Sample identifier & $\begin{array}{c}\text { Date sampled } \\
\text { (m/d/y) }\end{array}$ & $\begin{array}{c}\text { Calcium } \\
\text { (total) }\end{array}$ & $\begin{array}{c}\text { Chloride } \\
\text { (dissolved) }\end{array}$ & $\begin{array}{c}\text { Magnesium } \\
\text { (total) }\end{array}$ & $\begin{array}{c}\text { Potassium } \\
\text { (total) }\end{array}$ & $\begin{array}{c}\text { Sodium } \\
\text { (total) }\end{array}$ & $\begin{array}{c}\text { Sulfate } \\
\text { (dissolved) }\end{array}$ \\
\hline QAS-51 & $6 / 13 / 96$ & 66 & 60 & 21 & 4.5 & 11 & 69 \\
Z-value & $6 / 13 / 96$ & .77 & .30 & .74 & .21 & 0 & 0 \\
NRF-13 & $9 / 5 / 96$ & 64 & 60 & 19 & 4.2 & 62 & 73 \\
USGS 12 & $1 / 16 / 96$ & 70 & 38 & 24 & 2.1 & 17 & 34 \\
& $3 / 21 / 96$ & 77 & 40 & 23 & 2.1 & 16 & 36 \\
& $6 / 10 / 96$ & 66 & 38 & 24 & 2.0 & 16 & 34 \\
& $9 / 3 / 96$ & 68 & 38 & 23 & 1.9 & 17 & 35 \\
N & $1 / 17 / 96$ & 70 & 35 & 25 & 2.1 & 15 & 34 \\
& $3 / 25 / 96$ & 72 & 36 & 22 & 1.9 & 15 & 35 \\
& $6 / 11 / 96$ & 64 & 35 & 24 & 2.0 & 14 & 34 \\
& $9 / 4 / 96$ & 71 & 35 & 24 & 2.0 & 15 & 35 \\
& $1 / 17 / 96$ & 92 & 14 & 37 & 2.0 & 9.9 & 21 \\
USGS 97 & $3 / 21 / 96$ & 50 & 14 & 18 & 1.9 & 9.3 & 22 \\
& $6 / 11 / 96$ & 49 & 14 & 21 & 2.0 & 9.3 & 21 \\
& $9 / 4 / 96$ & 50 & 15 & 20 & 2.0 & 10 & 22 \\
& $1 / 17 / 96$ & 58 & 21 & 22 & 1.7 & 14 & 25 \\
& $3 / 25 / 96$ & 64 & 21 & 22 & 1.5 & 14 & 27 \\
& $6 / 11 / 96$ & 58 & 22 & 22 & 1.7 & 14 & 26 \\
& $9 / 4 / 96$ & 62 & 22 & 22 & 1.7 & 14 & 27
\end{tabular}


Table 3. Concentrations of dissolved anions and total recoverable cations in water, Naval Reactors Facility and vicinityContinued

\begin{tabular}{|c|c|c|c|c|c|c|c|}
\hline Sample identifier & $\begin{array}{l}\text { Date sampled } \\
\qquad(\mathrm{m} / \mathrm{d} / \mathrm{y})\end{array}$ & $\begin{array}{l}\text { Calcium } \\
\text { (total) }\end{array}$ & $\begin{array}{c}\text { Chloride } \\
\text { (dissolved) }\end{array}$ & $\begin{array}{c}\text { Magnesium } \\
\text { (total) }\end{array}$ & $\begin{array}{l}\text { Potassium } \\
\text { (total) }\end{array}$ & $\begin{array}{c}\text { Sodium } \\
\text { (total) }\end{array}$ & $\begin{array}{c}\text { Sulfate } \\
\text { (dissolved) }\end{array}$ \\
\hline \multirow[t]{4}{*}{ USGS 102} & $1 / 18 / 96$ & 69 & 34 & 25 & 2.1 & 14 & 33 \\
\hline & $3 / 19 / 96$ & 75 & 35 & 22 & 2.0 & 14 & 35 \\
\hline & $6 / 11 / 96$ & 66 & 34 & 24 & 2.2 & 14 & 33 \\
\hline & $9 / 4 / 96$ & 74 & 33 & 24 & 2.1 & 15 & 35 \\
\hline
\end{tabular}


Table 4. Concentrations of selected total recoverable trace elements and dissolved beryllium and thallium in water, Naval Reactors

\section{Facility and vicinity.}

[Analyses were performed by the U.S. Geological Survey National Water Quality Laboratory. Analytical results are in micrograms per liter. Sample identifier: see figure 2 for well locations. Date sampled: $(\mathrm{m} / \mathrm{d} / \mathrm{y})$, month/day/year. QAS indicates quality-assurance sample; 52 is a field-blank sample; others are replicates. Z-values associated with QA replicates were calculated using equation 1; (N) indicates that Z-value is greater than 1.96 and that the two results are not equivalent at the 95-percent confidence limit; $U$ indicates that statistical equivalence is uncertain. Symbol: <, concentration is less than the specified laboratory reporting level]

\begin{tabular}{|c|c|c|c|c|c|c|c|c|c|c|}
\hline \multirow{2}{*}{ Constituent } & \multicolumn{10}{|c|}{ Sample identifier and date sampled $(\mathrm{m} / \mathrm{d} / \mathrm{y})$} \\
\hline & $\begin{array}{c}\text { QAS-52 } \\
9 / 3 / 96\end{array}$ & $\begin{array}{l}\text { NRF-6 } \\
1 / 16 / 96\end{array}$ & $\begin{array}{l}\text { NRF-6 } \\
3 / 19 / 96\end{array}$ & $\begin{array}{l}\text { NRF-6 } \\
6 / 10 / 96\end{array}$ & $\begin{array}{l}\text { NRF-6 } \\
9 / 5 / 96\end{array}$ & $\begin{array}{l}\text { NRF-7 } \\
1 / 16 / 96\end{array}$ & $\begin{array}{l}\text { NRF-7 } \\
3 / 19 / 96\end{array}$ & $\begin{array}{c}\text { NRF-7 } \\
6 / 10 / / 96\end{array}$ & $\begin{array}{l}\text { NRF-7 } \\
\text { 9/3/96 }\end{array}$ & $\begin{array}{l}\text { NRF-8 } \\
1 / 17 / 96\end{array}$ \\
\hline Aluminum & $<10$ & 20 & $<10$ & $<10$ & $<10$ & 160 & 80 & 60 & 70 & 20 \\
\hline Antimony & $<1$ & $<1$ & $<1$ & 1 & 1 & $<1$ & $<1$ & $<1$ & $<1$ & $<1$ \\
\hline Arsenic & $<1$ & 3 & 3 & 3 & 3 & 2 & 2 & 2 & 2 & 2 \\
\hline Barium & $<100$ & $<100$ & $<100$ & $<100$ & $<100$ & $<100$ & $<100$ & $<100$ & $<100$ & 100 \\
\hline Beryllium (dissolved) & $<.5$ & $<.5$ & $<.5$ & $<.5$ & $<.5$ & $<.5$ & $<.5$ & $<.5$ & $<.5$ & $<.5$ \\
\hline Cadmium & $<1$ & $<1$ & $<1$ & $<1$ & $<1$ & $<1$ & $<1$ & $<1$ & $<1$ & $<1$ \\
\hline Chromium & $<1$ & 34 & 30 & 30 & 27 & 14 & 15 & 15 & 13 & 6.2 \\
\hline Copper & $<1$ & $<1$ & 1 & $<1$ & $<1$ & $<1$ & $<1$ & $<1$ & $<1$ & $<1$ \\
\hline Iron & $<10$ & 150 & 130 & 320 & 240 & 180 & 160 & 70 & 230 & 30 \\
\hline Lead & $<1$ & $<1$ & $<1$ & $<1$ & $<1$ & $<1$ & $<1$ & $<1$ & $<1$ & $<1$ \\
\hline Manganese & 10 & 10 & $<10$ & $<10$ & $<10$ & $<10$ & $<10$ & $<10$ & $<10$ & 10 \\
\hline Mercury & $<.1$ & $<.1$ & $<.1$ & $<.1$ & $<.1$ & $<.1$ & $<.1$ & $<.1$ & $<.1$ & $<.1$ \\
\hline Nickel & $<1$ & 6 & 8 & 11 & 8 & 5 & 6 & 6 & 6 & $<1$ \\
\hline Selenium & $<1$ & 2 & 2 & 2 & 2 & 1 & 1 & $<1$ & 1 & 2 \\
\hline Silver & $<1$ & $<1$ & $<1$ & $<1$ & $<1$ & $<1$ & $<1$ & $<1$ & $<1$ & $<1$ \\
\hline Thallium (dissolved) & $<.5$ & $<.5$ & $<.5$ & $<.5$ & $<.5$ & $<.5$ & $<.5$ & $<.5$ & $<.5$ & $<.5$ \\
\hline Zinc & $<10$ & $<10$ & 20 & $<10$ & $<10$ & $<10$ & $<10$ & $<10$ & $<10$ & $<10$ \\
\hline
\end{tabular}


Table 4. Concentrations of selected total recoverable trace elements and dissolved beryllium and thallium in water, Naval Reactors Facility and vicinity-Continued

\begin{tabular}{|c|c|c|c|c|c|c|c|c|c|c|c|}
\hline \multirow[b]{2}{*}{ Constituent } & \multicolumn{11}{|c|}{ Sample identifier and date sampled $(\mathrm{m} / \mathrm{d} / \mathrm{y})$} \\
\hline & $\begin{array}{l}\text { QAS-46 } \\
1 / 17 / 96\end{array}$ & $\begin{array}{l}\text { Z-value } \\
1 / 17 / 96\end{array}$ & $\begin{array}{l}\text { NRF-8 } \\
3 / 25 / 96\end{array}$ & $\begin{array}{l}\text { NRF-8 } \\
6 / 11 / 96\end{array}$ & $\begin{array}{l}\text { NRF-8 } \\
9 / 4 / 96\end{array}$ & $\begin{array}{l}\text { NRF-9 } \\
1 / 18 / 96\end{array}$ & $\begin{array}{l}\text { NRF-9 } \\
3 / 26 / 96\end{array}$ & $\begin{array}{l}\text { NRF-9 } \\
6 / 11 / 96\end{array}$ & $\begin{array}{l}\text { NRF-9 } \\
\text { 9/4/96 }\end{array}$ & $\begin{array}{c}\text { NRF-10 } \\
5 / 8 / 96\end{array}$ & $\begin{array}{l}\text { NRF-10 } \\
6 / 12 / 96\end{array}$ \\
\hline Aluminum & 30 & 0.94 & $<10$ & $<10$ & $<10$ & 20 & 30 & 40 & $<10$ & 2,000 & 520 \\
\hline Antimony & $<1$ & 0 & $<1$ & $<1$ & $<1$ & $<1$ & $<1$ & $<1$ & $<1$ & $<1$ & $<1$ \\
\hline Arsenic & 2 & 0 & 2 & 2 & 2 & 1 & 2 & 2 & 2 & 2 & 2 \\
\hline Barium & 100 & 0 & $<100$ & $<100$ & $<100$ & 100 & $<100$ & $<100$ & $<100$ & $<100$ & $<100$ \\
\hline Beryllium (dissolved) & $<.5$ & 0 & $<.5$ & $<.5$ & $<.5$ & $<.5$ & $<.5$ & $<.5$ & $<.5$ & $<.5$ & $<.5$ \\
\hline Cadmium & $<1$ & 0 & $<1$ & $<1$ & $<1$ & $<1$ & $<1$ & $<1$ & $<1$ & $<1$ & $<1$ \\
\hline Chromium & 6.2 & 0 & 6.5 & 7.1 & 7.1 & 11 & 12 & 14 & 12 & 17 & 17 \\
\hline Copper & 1 & 0 & $<1$ & $<1$ & $<1$ & $<1$ & $<1$ & $<1$ & $<1$ & 3 & $<1$ \\
\hline Iron & 50 & 1.69 & 30 & 40 & 80 & 20 & 190 & 60 & 30 & 2,900 & 770 \\
\hline Lead & $<1$ & 0 & $<1$ & $<1$ & $<1$ & $<1$ & $<1$ & $<1$ & $<1$ & $<1$ & $<1$ \\
\hline Manganese & $<10$ & 0 & $<10$ & $<10$ & $<10$ & $<10$ & $<10$ & $<10$ & $<10$ & 60 & 30 \\
\hline Mercury & $<.1$ & 0 & $<.1$ & $<.1$ & $<.1$ & $<.1$ & $<.1$ & $<.1$ & $<.1$ & $<.1$ & $<.1$ \\
\hline Nickel & $<1$ & 0 & $<1$ & $<1$ & 2 & $<1$ & $<1$ & $<1$ & $<1$ & 9 & 3 \\
\hline Selenium & 2 & 0 & 2 & 2 & 2 & 2 & 2 & 2 & 2 & 2 & 2 \\
\hline Silver & $<1$ & 0 & $<1$ & $<1$ & $<1$ & $<1$ & $<1$ & $<1$ & $<1$ & $<1$ & $<1$ \\
\hline Thallium (dissolved) & $<.5$ & 0 & $<.5$ & $<.5$ & $<.5$ & $<.5$ & $<.5$ & $<.5$ & $<.5$ & $<.5$ & $<.5$ \\
\hline Zinc & $<10$ & 0 & $<10$ & $<10$ & $<10$ & $<10$ & $<10$ & $<10$ & $<10$ & $<10$ & $<10$ \\
\hline
\end{tabular}


Table 4. Concentrations of selected total recoverable trace elements and dissolved beryllium and thallium in water, Naval Reactors Facility and vicinity-Continued

\begin{tabular}{|c|c|c|c|c|c|c|c|c|c|c|c|}
\hline \multirow[b]{2}{*}{ Constituent } & \multicolumn{11}{|c|}{ Sample identifier and date sampled $(\mathrm{m} / \mathrm{d} / \mathrm{y})$} \\
\hline & $\begin{array}{l}\text { QAS-50 } \\
6 / 12 / 96\end{array}$ & $\begin{array}{l}\text { Z-value } \\
6 / 12 / 96\end{array}$ & $\begin{array}{c}\text { NRF-10 } \\
9 / 4 / 96\end{array}$ & $\begin{array}{l}\text { NRF-11 } \\
1 / 18 / 96\end{array}$ & $\begin{array}{l}\text { NRF-11 } \\
3 / 25 / 96\end{array}$ & $\begin{array}{l}\text { QAS-49 } \\
3 / 25 / 96\end{array}$ & $\begin{array}{l}\text { Z-value } \\
3 / 25 / 96\end{array}$ & $\begin{array}{l}\text { NRF-11 } \\
6 / 12 / 96\end{array}$ & $\begin{array}{l}\text { NRF-11 } \\
9 / 5 / 96\end{array}$ & $\begin{array}{c}\text { NRF-12 } \\
1 / 22 / 96\end{array}$ & $\begin{array}{l}\text { NRF-12 } \\
3 / 20 / 96\end{array}$ \\
\hline Aluminum & 440 & $4.97(\mathrm{~N})$ & 1,000 & 70 & 40 & 40 & 0 & 60 & 40 & 60 & 60 \\
\hline Antimony & $<1$ & 0 & $<1$ & $<1$ & $<1$ & $<1$ & 0 & $<1$ & $<1$ & $<1$ & $<1$ \\
\hline Arsenic & 2 & 0 & 2 & 2 & 2 & 2 & 0 & 2 & 2 & 2 & 2 \\
\hline Barium & $<100$ & 0 & $<100$ & 100 & 100 & $<100$ & .94 & $<100$ & $<100$ & 200 & $<100$ \\
\hline Beryllium (dissolved) & $<.5$ & 0 & $<.5$ & $<.5$ & $<.5$ & $<.5$ & 0 & $<.5$ & $<.5$ & $<.5$ & $<.5$ \\
\hline Cadmium & $<1$ & 0 & $<1$ & $<1$ & $<1$ & $<1$ & 0 & $<1$ & $<1$ & $<1$ & $<1$ \\
\hline Chromium & 17 & 0 & 14 & 21 & 23 & 22 & .28 & 24 & 23 & 18 & 19 \\
\hline Copper & $<1$ & 0 & 1 & $<1$ & 1 & $<1$ & 0 & $<1$ & $<1$ & $<1$ & $<1$ \\
\hline Iron & 640 & $3.09(\mathrm{~N})$ & 1,700 & 70 & 100 & 60 & $2.92(\mathrm{~N})$ & 320 & 60 & 40 & 110 \\
\hline Lead & $<1$ & 0 & 2 & $<1$ & $<1$ & $<1$ & 0 & $<1$ & $<1$ & $<1$ & $<1$ \\
\hline Manganese & 30 & 0 & 40 & $<10$ & $<10$ & $<10$ & 0 & $<10$ & $<10$ & $<10$ & $<10$ \\
\hline Mercury & $<.1$ & 0 & $<.1$ & $<.1$ & $<.1$ & $<.1$ & 0 & $<.1$ & $<.1$ & $<.1$ & $<.1$ \\
\hline Nickel & 3 & 0 & 8 & 3 & 3 & 3 & 0 & 6 & 7 & $<1$ & $<1$ \\
\hline Selenium & 2 & 0 & 2 & 2 & 2 & 2 & 0 & 2 & 2 & 2 & 2 \\
\hline Silver & $<1$ & 0 & $<1$ & 3 & $<1$ & $<1$ & 0 & $<1$ & $<1$ & $<1$ & $<1$ \\
\hline Thallium (dissolved) & $<.5$ & $\mathbf{0}$ & $<.5$ & $<.5$ & $<.5$ & $<.5$ & 0 & $<.5$ & $<.5$ & $<.5$ & $<.5$ \\
\hline Zinc & $<10$ & 0 & $<10$ & $<10$ & 20 & $<10$ & 0 & $<10$ & $<10$ & $<10$ & $<10$ \\
\hline
\end{tabular}


Table 4. Concentrations of selected total recoverable trace elements and dissolved beryllium and thallium in water, Naval Reactors Facility and vicinity-Continued

\begin{tabular}{|c|c|c|c|c|c|c|c|c|c|c|}
\hline \multirow[b]{2}{*}{ Constituent } & \multicolumn{10}{|c|}{ Sample identifier and date sampled $(\mathrm{m} / \mathrm{d} / \mathrm{y})$} \\
\hline & $\begin{array}{l}\text { NRF-12 } \\
6 / 12 / 96\end{array}$ & $\begin{array}{c}\text { NRF-12 } \\
9 / 5 / 96\end{array}$ & $\begin{array}{c}\text { NRF-13 } \\
1 / 22 / 96\end{array}$ & $\begin{array}{l}\text { NRF-13 } \\
3 / 20 / 96\end{array}$ & $\begin{array}{l}\text { NRF-13 } \\
6 / 13 / 96\end{array}$ & $\begin{array}{l}\text { QAS-51 } \\
6 / 13 / 96\end{array}$ & $\begin{array}{l}\text { Z-value } \\
6 / 13 / 96\end{array}$ & $\begin{array}{c}\text { NRF-13 } \\
9 / 5 / 96\end{array}$ & $\begin{array}{c}\text { USGS } 12 \\
1 / 16 / 96\end{array}$ & $\begin{array}{c}\text { USGS } 12 \\
3 / 21 / 96\end{array}$ \\
\hline Aluminum & 20 & 10 & 2,800 & $<10$ & 3,500 & 3,400 & 1.61 & 1,400 & $<10$ & $<10$ \\
\hline Antimony & $<1$ & $<1$ & $<1$ & $<1$ & 1 & $<1$ & $\mathrm{U}$ & $<1$ & $<1$ & $<1$ \\
\hline Arsenic & 2 & 2 & 2 & 2 & 2 & 2 & 0 & 1 & 2 & 2 \\
\hline Barium & $<100$ & $<100$ & 100 & $<100$ & $<100$ & $<100$ & 0 & $<100$ & 100 & 100 \\
\hline Beryllium (dissolved) & $<.5$ & $<.5$ & $<.5$ & $<.5$ & $<.5$ & $<.5$ & 0 & $<.5$ & $<.5$ & $<.5$ \\
\hline Cadmium & $<1$ & $<1$ & $<1$ & $<1$ & $<1$ & $<1$ & 0 & $<1$ & $<1$ & $<1$ \\
\hline Chromium & 20 & 17 & 31 & 30 & 34 & 35 & .22 & 26 & 6.5 & 6.9 \\
\hline Copper & $<1$ & $<1$ & 5 & 7 & 6 & 7 & .42 & 2 & $<1$ & $<1$ \\
\hline Iron & 20 & $<10$ & 2,500 & 3,400 & 3,100 & 5,400 & $11.01(\mathrm{~N})$ & 1,300 & 30 & 50 \\
\hline Lead & $<1$ & $<1$ & 1 & 2 & 1 & 2 & .67 & $<1$ & $<1$ & $<1$ \\
\hline Manganese & $<10$ & $<10$ & 40 & 60 & 60 & 60 & 0 & $<10$ & $<10$ & $<10$ \\
\hline Mercury & $<.1$ & $<.1$ & $<.1$ & $<.1$ & $<.1$ & $<.1$ & 0 & $<.1$ & $<.1$ & $<.1$ \\
\hline Nickel & $<1$ & $<1$ & 6 & 8 & 10 & 10 & 0 & 5 & $<1$ & $<1$ \\
\hline Selenium & 2 & 2 & 1 & 1 & 1 & 1 & 0 & 1 & 2 & 2 \\
\hline Silver & 2 & $<1$ & $<1$ & $<1$ & $<1$ & $<1$ & 0 & $<1$ & $<1$ & $<1$ \\
\hline Thallium (dissolved) & $<.5$ & $<.5$ & $<.5$ & $<.5$ & $<.5$ & $<.5$ & 0 & $<.5$ & $<.5$ & $<.5$ \\
\hline Zinc & $<10$ & $<10$ & $<10$ & 10 & $<10$ & $<10$ & 0 & $<10$ & $<10$ & $<10$ \\
\hline
\end{tabular}


Table 4. Concentrations of selected total recoverable trace elements and dissolved beryllium and thallium in water, Naval Reactors Facility and vicinity-Continued

\begin{tabular}{|c|c|c|c|c|c|c|c|c|c|c|}
\hline \multirow[b]{2}{*}{ Constituent } & \multicolumn{10}{|c|}{ Sample identifier and date sampled $(\mathrm{m} / \mathrm{d} / \mathrm{y})$} \\
\hline & $\begin{array}{c}\text { USGS } 12 \\
6 / 10 / 96\end{array}$ & $\begin{array}{c}\text { USGS } 12 \\
9 / 3 / 96\end{array}$ & $\begin{array}{c}\text { USGS } 97 \\
1 / 17 / 96\end{array}$ & $\begin{array}{c}\text { USGS } 97 \\
3 / 25 / 96\end{array}$ & $\begin{array}{c}\text { USGS } 97 \\
6 / 11 / 96\end{array}$ & $\begin{array}{c}\text { USGS } 97 \\
9 / 4 / 96\end{array}$ & $\begin{array}{c}\text { USGS } 98 \\
1 / 17 / 96\end{array}$ & $\begin{array}{c}\text { USGS } 98 \\
3 / 21 / 96\end{array}$ & $\begin{array}{c}\text { USGS } 98 \\
6 / 11 / 96\end{array}$ & $\begin{array}{c}\text { USGS } 98 \\
9 / 4 / 96\end{array}$ \\
\hline Aluminum & $<10$ & $<10$ & 20 & $<10$ & 40 & 20 & $<10$ & $<10$ & $<10$ & $<10$ \\
\hline Antimony & $<1$ & $<1$ & $<1$ & $<1$ & $<1$ & $<1$ & $<1$ & $<1$ & $<1$ & $<1$ \\
\hline Arsenic & 2 & 2 & 1 & 2 & 2 & 2 & 2 & 2 & 1 & 2 \\
\hline Barium & $<100$ & $<100$ & 100 & $<100$ & $<100$ & $<100$ & $<100$ & $<100$ & $<100$ & $<100$ \\
\hline Beryllium (dissolved) & $<.5$ & $<.5$ & $<.5$ & $<.5$ & $<.5$ & $<.5$ & $<.5$ & $<.5$ & $<.5$ & $<.5$ \\
\hline Cadmium & $<1$ & $<1$ & $<1$ & $<1$ & $<1$ & $<1$ & $<1$ & $<1$ & $<1$ & $<1$ \\
\hline Chromium & 7.8 & 6.8 & 6.2 & 6.1 & 6.5 & 6.6 & 5.3 & 5.1 & 6.6 & 5.6 \\
\hline Copper & $<1$ & $<1$ & 1 & $<1$ & $<1$ & $<1$ & $<1$ & 7 & $<1$ & $<1$ \\
\hline Iron & 30 & 50 & 40 & 30 & 20 & 50 & 80 & 120 & 260 & 60 \\
\hline Lead & $<1$ & $<1$ & 1 & 1 & $<1$ & 1 & 7 & 7 & 7 & 6 \\
\hline Manganese & $<10$ & $<10$ & $<10$ & $<10$ & $<10$ & $<10$ & $<10$ & $<10$ & $<10$ & $<10$ \\
\hline Mercury & $<.1$ & $<.1$ & $<.1$ & $<.1$ & $<.1$ & $<.1$ & $<.1$ & $<.1$ & $<.1$ & $<.1$ \\
\hline Nickel & $<1$ & $<1$ & $<1$ & $<1$ & $<1$ & $<1$ & $<1$ & $<1$ & $<1$ & $<1$ \\
\hline Selenium & 2 & 2 & 2 & 2 & 2 & 2 & 1 & 1 & 1 & $<1$ \\
\hline Silver & $<1$ & $<1$ & $<1$ & $<1$ & $<1$ & $<1$ & $<1$ & $<1$ & $<1$ & $<1$ \\
\hline Thallium (dissolved) & $<.5$ & $<.5$ & $<.5$ & $<.5$ & $<.5$ & $<.5$ & $<.5$ & $<.5$ & $<.5$ & $<.5$ \\
\hline Zinc & $<10$ & $<10$ & 100 & 90 & 100 & 80 & 180 & 170 & 180 & 160 \\
\hline
\end{tabular}


Table 4. Concentrations of selected total recoverable trace elements and dissolved beryllium and thallium in water, Naval Reactors Facility and vicinity-Continued

\begin{tabular}{|c|c|c|c|c|c|c|c|c|}
\hline \multirow[b]{2}{*}{ Constituent } & \multicolumn{8}{|c|}{ Sample identifier and date sampled $(\mathrm{m} / \mathrm{d} / \mathrm{y})$} \\
\hline & $\begin{array}{c}\text { USGS } 99 \\
1 / 17 / 96\end{array}$ & $\begin{array}{c}\text { USGS } 99 \\
3 / 25 / 96\end{array}$ & $\begin{array}{c}\text { USGS } 99 \\
6 / 11 / 96\end{array}$ & $\begin{array}{c}\text { USGS-99 } \\
9 / 4 / 96\end{array}$ & $\begin{array}{c}\text { USGS } 102 \\
1 / 18 / 96\end{array}$ & $\begin{array}{c}\text { USGS } 102 \\
3 / 19 / 96\end{array}$ & $\begin{array}{c}\text { USGS } 102 \\
6 / 11 / 96\end{array}$ & $\begin{array}{c}\text { USGS } 102 \\
9 / 4 / 96\end{array}$ \\
\hline Aluminum & $<10$ & $<10$ & $<10$ & 20 & 10 & 20 & $<10$ & 10 \\
\hline Antimony & $<1$ & $<1$ & $<1$ & $<1$ & $<1$ & $<1$ & $<1$ & $<1$ \\
\hline Arsenic & 1 & 2 & 1 & 2 & 2 & 2 & 2 & 2 \\
\hline Barium & 100 & $<100$ & $<100$ & $<100$ & 100 & $<100$ & $<100$ & $<100$ \\
\hline Beryllium (dissolved) & $<.5$ & $<.5$ & $<.5$ & $<.5$ & $<.5$ & $<.5$ & $<.5$ & $<.5$ \\
\hline Cadmium & $<1$ & $<1$ & $<1$ & $<1$ & $<1$ & $<1$ & $<1$ & $<1$ \\
\hline Chromium & 5.1 & 5.9 & 5.6 & 5.5 & 6.3 & 6.4 & 7.1 & 6.6 \\
\hline Copper & $<1$ & 2 & 3 & $<1$ & $<1$ & $<1$ & $<1$ & $<1$ \\
\hline Iron & 50 & 70 & 90 & 70 & 160 & 260 & 110 & 20 \\
\hline Lead & 1 & 2 & $<1$ & 1 & $<1$ & $<1$ & $<1$ & $<1$ \\
\hline Manganese & $<10$ & $<10$ & $<10$ & $<10$ & $<10$ & $<10$ & $<10$ & $<10$ \\
\hline Mercury & $<.1$ & $<, 1$ & $<.1$ & $<.1$ & $<.1$ & $<, 1$ & $<.1$ & $<.1$ \\
\hline Nickel & $<1$ & 1 & $<1$ & $<1$ & $<1$ & $<1$ & $<1$ & $<1$ \\
\hline Selenium & 1 & 2 & 2 & 1 & 2 & 2 & 2 & 2 \\
\hline Silver & $<1$ & $<1$ & $<1$ & $<1$ & $<1$ & $<1$ & $<1$ & $<1$ \\
\hline Thallium (dissolved) & $<.5$ & $<.5$ & $<.5$ & $<.5$ & $<.5$ & $<.5$ & $<.5$ & $<.5$ \\
\hline Zinc & 80 & 90 & 90 & 70 & $<10$ & $<10$ & $<10$ & $<10$ \\
\hline
\end{tabular}




\section{Table 5. Concentrations of dissolved and total nutrients, and total organic carbon in water, Naval Reactors Facility and vicinity.}

[Analyses were performed by the U.S. Geological Survey National Water Quality Laboratory. Analytical results are in milligrams per liter. Sample identifier: see figure 2 for well locations. Date sampled: $(\mathrm{m} / \mathrm{d} / \mathrm{y})$, month/day/year. QAS indicates quality-assurance sample: 47 is a blank total organic carbon sample and 52 is a field-blank sample; all others are replicates; $Z$-values associated with QA replicates were calculated using equation 1 . (N) indicates that $Z$-value is greater than 1.96 and that the two results are not equivalent at the 95-percent confidence limit. Symbols: $<$, concentration is less than the specified laboratory reporting level. Abbreviation: NR, analysis was not requested]

\begin{tabular}{|c|c|c|c|c|c|c|}
\hline $\begin{array}{l}\text { Sample } \\
\text { identifier }\end{array}$ & $\begin{array}{l}\text { Date sampled } \\
(\mathrm{m} / \mathrm{d} / \mathrm{y})\end{array}$ & $\begin{array}{c}\text { Ammonia } \\
\text { plus organic } \\
\text { nitrogen (as } \\
\text { nitrogen) } \\
\text { (total) }\end{array}$ & $\begin{array}{c}\text { Nitrite (as } \\
\text { nitrogen) } \\
\text { (dissolved) }\end{array}$ & $\begin{array}{c}\text { Nitrite plus } \\
\text { nitrate (as } \\
\text { nitrogen) } \\
\text { (dissolved) }\end{array}$ & $\begin{array}{l}\text { Phosphorus } \\
\text { (as } \\
\text { phosphorus) } \\
\text { (total) }\end{array}$ & $\begin{array}{c}\text { Total organic } \\
\text { carbon }\end{array}$ \\
\hline QAS-47 & $1 / 23 / 96$ & NR & NR & NR & NR & 0.1 \\
\hline QAS-52 & $9 / 3 / 96$ & $<0.2$ & $<0.01$ & $<0.05$ & $<0.01$ & .2 \\
\hline \multirow[t]{4}{*}{ NRF-6 } & $1 / 16 / 96$ & $<.2$ & $<.01$ & 1.9 & .07 & 2.3 \\
\hline & $3 / 19 / 96$ & $<.2$ & $<.01$ & 1.9 & .1 & .9 \\
\hline & $6 / 10 / 96$ & $<.2$ & $<.01$ & 1.9 & .05 & 1.1 \\
\hline & $9 / 10 / 96$ & $<.2$ & $<.01$ & 1.7 & .08 & 1.2 \\
\hline \multirow[t]{4}{*}{ NRF-7 } & $1 / 16 / 96$ & $<.2$ & $<.01$ & .49 & $<.01$ & .8 \\
\hline & $3 / 19 / 96$ & $<.2$ & $<.01$ & .46 & .01 & .3 \\
\hline & $6 / 10 / 96$ & $<.2$ & $<.01$ & .5 & .03 & $<.1$ \\
\hline & $9 / 13 / 96$ & $<.2$ & $<.01$ & .47 & .02 & .5 \\
\hline NRF-8 & $1 / 17 / 96$ & $<.2$ & $<.01$ & 2.0 & .02 & .3 \\
\hline QAS-46 & $1 / 17 / 96$ & $<.2$ & $<.01$ & 2.0 & .01 & 3.4 \\
\hline Z-value & $1 / 17 / 96$ & 0 & 0 & 0 & .67 & $15.72(\mathrm{~N})$ \\
\hline \multirow[t]{3}{*}{ NRF-8 } & $3 / 25 / 96$ & $<.2$ & $<.01$ & 1.9 & $<.01$ & 4.9 \\
\hline & $6 / 11 / 96$ & $<.2$ & .01 & 2.0 & .04 & .7 \\
\hline & $9 / 10 / 96$ & $<.2$ & $<.01$ & 1.9 & .03 & .5 \\
\hline \multirow[t]{4}{*}{ NRF-9 } & $1 / 18 / 96$ & $<.2$ & $<.01$ & 2.3 & .03 & .4 \\
\hline & $3 / 26 / 96$ & $<.2$ & $<.01$ & 2.2 & $<.01$ & .9 \\
\hline & $6 / 11 / 96$ & $<.2$ & .01 & 2.4 & .03 & .4 \\
\hline & $9 / 10 / 96$ & $<.2$ & $<.01$ & 2.2 & .02 & .6 \\
\hline \multirow[t]{2}{*}{ NRF-10 } & $5 / 8 / 96$ & $<.2$ & $<.01$ & 1.8 & .09 & .1 \\
\hline & $6 / 12 / 96$ & $<.2$ & .01 & 1.9 & .06 & 1.7 \\
\hline QAS-50 & $6 / 12 / 96$ & $<.2$ & .02 & 1.9 & .05 & 1.0 \\
\hline Z-value & $6 / 12 / 96$ & 0 & .94 & 0 & .58 & $3.81(\mathrm{~N})$ \\
\hline
\end{tabular}


Table 5. Concentrations of dissolved and total nutrients, and total organic carbon in water, Naval Reactors Facility and vicinity-Continued

\begin{tabular}{|c|c|c|c|c|c|c|}
\hline $\begin{array}{l}\text { Sample } \\
\text { identifier }\end{array}$ & $\begin{array}{l}\text { Date sampled } \\
(\mathrm{m} / \mathrm{d} / \mathrm{y})\end{array}$ & $\begin{array}{l}\text { Ammonia } \\
\text { plus organic } \\
\text { nitrogen (as } \\
\text { nitrogen) } \\
\text { (total) }\end{array}$ & $\begin{array}{l}\text { Nitrite (as } \\
\text { nitrogen) } \\
\text { (dissolved) }\end{array}$ & $\begin{array}{c}\text { Nitrite plus } \\
\text { nitrate (as } \\
\text { nitrogen) } \\
\text { (dissolved) }\end{array}$ & $\begin{array}{l}\text { Phosphorus } \\
\text { (as } \\
\text { phosphorus) } \\
\text { (total) }\end{array}$ & $\begin{array}{l}\text { Total organic } \\
\text { carbon }\end{array}$ \\
\hline NRF-10 & $9 / 10 / 96$ & $<.2$ & $<.01$ & 1.8 & .02 & .4 \\
\hline \multirow[t]{2}{*}{ NRF-11 } & $1 / 18 / 96$ & $<.2$ & $<.01$ & 2.0 & .01 & 2.5 \\
\hline & $3 / 25 / 96$ & $<.2$ & $<.01$ & 1.9 & .04 & .5 \\
\hline QAS-49 & $3 / 25 / 96$ & $<.2$ & $<.01$ & 1.9 & $<.01$ & .3 \\
\hline Z-value & $3 / 25 / 96$ & 0 & 0 & 0 & $2.20(\mathrm{~N})$ & 1.09 \\
\hline \multirow[t]{2}{*}{ NRF-11 } & $6 / 12 / 96$ & $<.2$ & .01 & 2.0 & .04 & 3.5 \\
\hline & $9 / 10 / 96$ & $<.2$ & $<.01$ & 1.9 & .02 & 2.9 \\
\hline \multirow[t]{4}{*}{ NRF-12 } & $1 / 22 / 96$ & $<.2$ & $<.01$ & 2.1 & $<.01$ & 2.5 \\
\hline & $3 / 20 / 96$ & $<.2$ & $<.01$ & 1.9 & .03 & 1.2 \\
\hline & $6 / 12 / 96$ & $<.2$ & .01 & 2.1 & .03 & .5 \\
\hline & $9 / 10 / 96$ & $<.2$ & $<.01$ & 2.0 & .01 & 2.1 \\
\hline \multirow[t]{3}{*}{ NRF-13 } & $1 / 22 / 96$ & $<.2$ & $<.01$ & .81 & .09 & 1.8 \\
\hline & $3 / 20 / 96$ & $<.2$ & $<.01$ & .74 & .16 & 1.0 \\
\hline & $6 / 13 / 96$ & $<.2$ & .02 & .8 & .15 & .2 \\
\hline QAS-51 & $6 / 13 / 96$ & $<.2$ & .02 & .81 & .16 & 3.9 \\
\hline Z-value & $6 / 13 / 96$ & 0 & 0 & .17 & .44 & $18.77(\mathrm{~N})$ \\
\hline NRF-13 & $9 / 11 / 96$ & $<.2$ & .01 & .75 & .17 & .9 \\
\hline \multirow[t]{4}{*}{ USGS 12} & $1 / 16 / 96$ & $<.2$ & $<.01$ & 2.2 & $<.01$ & 1.7 \\
\hline & $3 / 21 / 96$ & $<.2$ & $<.01$ & 2.1 & .03 & .8 \\
\hline & $6 / 10 / 96$ & $<.2$ & $<.01$ & 2.2 & $<.01$ & 2.0 \\
\hline & $9 / 3 / 96$ & $<.2$ & $<.01$ & 2.0 & .03 & 1.9 \\
\hline \multirow[t]{4}{*}{ USGS 97} & $1 / 17 / 96$ & $<.2$ & $<.01$ & 2.2 & $<.01$ & 1.6 \\
\hline & $3 / 25 / 96$ & $<.2$ & $<.01$ & 2.0 & .05 & .6 \\
\hline & $6 / 11 / 96$ & $<.2$ & .01 & 2.1 & .04 & .6 \\
\hline & $9 / 4 / 96$ & 4.1 & $<.01$ & 2.1 & .03 & .4 \\
\hline \multirow[t]{4}{*}{ USGS 98} & $1 / 17 / 96$ & $<.2$ & $<.01$ & 1.2 & $<.01$ & .6 \\
\hline & $3 / 21 / 96$ & $<.2$ & $<.01$ & 1.1 & .03 & .7 \\
\hline & $6 / 11 / 96$ & $<.2$ & .01 & 1.2 & .03 & .4 \\
\hline & $9 / 4 / 96$ & $<.2$ & $<.01$ & 1.1 & .06 & .8 \\
\hline
\end{tabular}


Table 5. Concentrations of dissolved and total nutrients, and total organic carbon in water, Naval Reactors Facility and vicinity-Continued

\begin{tabular}{ccccccc}
\hline $\begin{array}{c}\text { Sample } \\
\text { identifier }\end{array}$ & $\begin{array}{c}\text { Date sampled } \\
(\mathrm{m} / \mathrm{d} / \mathrm{y})\end{array}$ & $\begin{array}{c}\text { Ammonia } \\
\text { plus organic } \\
\text { nitrogen (as } \\
\text { nitrogen) } \\
\text { (total) }\end{array}$ & $\begin{array}{c}\text { Nitrite (as } \\
\text { nitrogen) } \\
\text { (dissolved) }\end{array}$ & $\begin{array}{c}\text { Nitrite plus } \\
\text { nitrate (as } \\
\text { nitrogen) } \\
\text { (dissolved) }\end{array}$ & $\begin{array}{c}\text { Phosphorus } \\
\text { (as } \\
\text { phosphorus) } \\
\text { (total) }\end{array}$ & $\begin{array}{c}\text { Total organic } \\
\text { carbon }\end{array}$ \\
\hline USGS 99 & $1 / 17 / 96$ & $<.2$ & $<.01$ & 1.7 & .01 & .3 \\
& $3 / 25 / 96$ & $<.2$ & $<.01$ & 1.6 & .01 & .2 \\
& $6 / 11 / 96$ & $<.2$ & .02 & 1.7 & .04 & 2.4 \\
& $9 / 4 / 96$ & $<.2$ & $<.01$ & 1.6 & .04 & 2.3 \\
& $1 / 18 / 96$ & $<.2$ & $<.01$ & 2.1 & $<.01$ & .8 \\
& $3 / 19 / 96$ & $<.2$ & $<.01$ & 2.0 & .02 & .4 \\
& $6 / 11 / 96$ & $<.2$ & .01 & 2.1 & .05 & .5 \\
& $9 / 10 / 96$ & $<.2$ & $<.01$ & 2.0 & $<.01$ & 2.3 \\
\hline
\end{tabular}


Table 6. Concentrations of gross alpha-particle radioactivity, gross beta-particle radioactivity, strontium-90, and tritium in water, Naval Reactors Facility and vicinity

[Analyses were performed by the U.S. Geological Survey National Water Quality Laboratory using a residue procedure for gross alpha- and beta-particle radioactivity, chemical separation for strontium-90, and liquid scintillation for tritium. Analytical results and uncertainties-for example, 8.23 $\pm 1.18-i n$ indicated units. Analytical uncertainties are reported as $1 \mathrm{~s}$. Concentrations that meet or exceed the reporting level of 3 times the $1 \mathrm{~s}$ value are shown in boldface type. Sample identifier: see figure 2 for well locations. Date sampled: ( $\mathrm{m} / \mathrm{d} / \mathrm{y})$, month/day/year. QAS indicates quality-assurance sample: 52 is a field-blank sample; others are replicates. Z-values associated with QA replicates were calculated using equation 1. $(\mathrm{N})$ indicates that $Z$-value is greater than 1.96 and that the two results are not equivalent at the 95 -percent confidence limit. Abbreviations: $\mathrm{pCi} / \mathrm{L}$, picocurie per liter; $\mu \mathrm{g} / \mathrm{L}$, microgram per liter; Sr-90/Y-90, strontium-90 in equilibrium with yttrium-90; NR, analysis was not requested; NC, value was not calculated]

\begin{tabular}{|c|c|c|c|c|c|c|c|}
\hline \multirow[b]{2}{*}{ Sample identifier } & \multirow{2}{*}{$\begin{array}{l}\text { Date sampled } \\
(\mathrm{m} / \mathrm{d} / \mathrm{y})\end{array}$} & \multicolumn{2}{|c|}{ Gross alpha-particle radioactivity } & \multicolumn{2}{|c|}{ Gross beta-particle radioactivity } & \multirow{2}{*}{$\begin{array}{l}\text { Strontium-90 } \\
(\mathrm{pCi} / \mathrm{L})\end{array}$} & \multirow{2}{*}{$\begin{array}{l}\text { Tritium } \\
(\mathrm{pCi} / \mathrm{L})\end{array}$} \\
\hline & & $\begin{array}{l}\text { as Thorium-230 } \\
(\mathrm{pCi} / \mathrm{L})\end{array}$ & $\begin{array}{l}\text { as Uranium } \\
(\mu \mathrm{g} / \mathrm{L})\end{array}$ & $\begin{array}{l}\text { as Cesium-137 } \\
(\mathrm{pCi} / \mathrm{L})\end{array}$ & $\begin{array}{c}\text { as } \mathrm{Sr}^{90} / \mathrm{Y}^{90} \\
(\mathrm{pCi} / \mathrm{L})\end{array}$ & & \\
\hline QAS-52 & $9 / 3 / 96$ & $-0.132 \pm 0.085$ & NR & $0.695 \pm 0.276$ & NR & $0.292 \pm 0.172$ & $76.8 \pm 12.8$ \\
\hline \multirow[t]{4}{*}{ NRF-6 } & $1 / 16 / 96$ & $2.22 \pm 1.42$ & $2.88 \pm 1.84$ & $8.23 \pm 1.18$ & $6.19 \pm 0.89$ & $-0.112 \pm 0.11$ & $64.0 \pm 12.8$ \\
\hline & $3 / 19 / 96$ & $.316 \pm 1.75$ & $.734 \pm 4.06$ & $12.0 \pm 4.68$ & $10.1 \pm 3.87$ & $-.134 \pm 0.136$ & $83.2 \pm 12.8$ \\
\hline & $6 / 10 / 96$ & $1.36 \pm 1.36$ & NR & $8.12 \pm 3.98$ & NR & $.191 \pm 0.170$ & $54.4 \pm 12.8$ \\
\hline & $9 / 5 / 96$ & $1.91 \pm 1.70$ & NR & $9.89 \pm 2.98$ & NR & $.067 \pm 0.136$ & $89.6 \pm 12.8$ \\
\hline \multirow[t]{4}{*}{ NRF-7 } & $1 / 16 / 96$ & $.780 \pm 0.386$ & $1.08 \pm 0.535$ & $4.40 \pm 0.640$ & $3.41 \pm 0.403$ & $.0266 \pm 0.145$ & $12.8 \pm 12.8$ \\
\hline & $3 / 19 / 96$ & $1.69 \pm 0.95$ & $3.07 \pm 1.73$ & $7.30 \pm 1.16$ & $3.97 \pm 0.457$ & $.049 \pm 0.126$ & $0.0 \pm 12.8$ \\
\hline & $6 / 10 / 96$ & $1.54 \pm 0.80$ & NR & $6.83 \pm 1.18$ & NR & $-.0105 \pm 0.022$ & $-12.8 \pm 12.8$ \\
\hline & $9 / 3 / 96$ & $1.41 \pm 0.76$ & NR & $5.68 \pm 0.88$ & NR & $.070 \pm 0.118$ & $12.8 \pm 12.8$ \\
\hline NRF-8 & $1 / 17 / 96$ & $3.20 \pm 0.89$ & $4.53 \pm 1.26$ & $3.18 \pm 0.585$ & $2.34 \pm 0.396$ & $.0652 \pm 0.13$ & $6.72 \pm 12.8$ \\
\hline QAS-46 & $1 / 17 / 96$ & $3.72 \pm 0.94$ & $5.16 \pm 1.31$ & $3.58 \pm 0.53$ & $2.72 \pm 0.402$ & $.121 \pm 0.14$ & $57.6 \pm 12.8$ \\
\hline Z-value & $1 / 17 / 96$ & .40 & .35 & .51 & .67 & .29 & .53 \\
\hline \multirow[t]{2}{*}{ NRF-8 } & $3 / 25 / 96$ & $2.85 \pm 1.26$ & $6.82 \pm 3.04$ & $7.36 \pm 1.82$ & $3.58 \pm 0.78$ & $.019 \pm 0.114$ & $38.4 \pm 12.8$ \\
\hline & $6 / 11 / 96$ & $.912 \pm 0.92$ & NR & $7.17 \pm 2.28$ & NR & $.023 \pm 0.117$ & $54.4 \pm 12.8$ \\
\hline
\end{tabular}


Table 6. Concentrations of gross alpha-particle radioactivity, gross beta-particle radioactivity, strontium-90, and tritium in water, Naval Reactors Facility and vicinity-Continued

\begin{tabular}{|c|c|c|c|c|c|c|c|}
\hline \multirow[b]{2}{*}{ Sample identifier } & \multirow{2}{*}{$\begin{array}{l}\text { Date sampled } \\
(\mathrm{m} / \mathrm{d} / \mathrm{y})\end{array}$} & \multicolumn{2}{|c|}{ Gross alpha-particle radioactivity } & \multicolumn{2}{|c|}{ Gross beta-particle radioactivity } & \multirow{2}{*}{$\begin{array}{l}\text { Strontium-90 } \\
(\mathrm{pCi} / \mathrm{L})\end{array}$} & \multirow{2}{*}{$\begin{array}{l}\text { Tritium } \\
(\mathrm{pCi} / \mathrm{L})\end{array}$} \\
\hline & & $\begin{array}{l}\text { as Thorium-230 } \\
(\mathrm{pCi} / \mathrm{L})\end{array}$ & $\begin{array}{l}\text { as Uranium } \\
(\mu \mathrm{g} / \mathrm{L})\end{array}$ & $\begin{array}{l}\text { as Cesium-137 } \\
(\mathrm{pCi} / \mathrm{L})\end{array}$ & $\begin{array}{c}\text { as } \mathrm{Sr}^{90} / \mathrm{Y}^{90} \\
(\mathrm{pCi} / \mathrm{L})\end{array}$ & & \\
\hline NRF-8 - Cont. & $9 / 4 / 96$ & $1.43 \pm 1.09$ & NR & $11.4 \pm 2.16$ & NR & $.019 \pm 0.106$ & $57.6 \pm 12.8$ \\
\hline \multirow[t]{4}{*}{ NRF-9 } & $1 / 18 / 96$ & $2.65 \pm 0.84$ & $4.14 \pm 1.32$ & $4.18 \pm 0.70$ & $3.08 \pm 0.463$ & $.197 \pm 0.150$ & $147.2 \pm 16.0$ \\
\hline & $3 / 26 / 96$ & $1.60 \pm 1.14$ & $3.98 \pm 2.84$ & $8.36 \pm 1.96$ & $4.04 \pm 0.82$ & $.182 \pm 0.138$ & $115.2 \pm 12.8$ \\
\hline & $6 / 11 / 96$ & $3.99 \pm 1.32$ & NR & $6.32 \pm 1.77$ & NR & $.311 \pm 0.124$ & $112.0 \pm 12.8$ \\
\hline & $9 / 4 / 96$ & $4.19 \pm 1.45$ & NR & $9.17 \pm 2.00$ & NR & $.329 \pm 0.126$ & $131.2 \pm 12.8$ \\
\hline \multirow[t]{2}{*}{ NRF-10 } & $5 / 8 / 96$ & $1.70 \pm 0.89$ & $4.11 \pm 2.18$ & $2.57 \pm 1.85$ & $2.12 \pm 1.52$ & $1.31 \pm 0.195$ & $140.8 \pm 12.8$ \\
\hline & $6 / 12 / 96$ & $1.92 \pm 1.00$ & NR & $7.50 \pm 1.78$ & NR & $.093 \pm 0.119$ & $137.6 \pm 12.8$ \\
\hline QAS-50 & $6 / 12 / 96$ & $2.86 \pm 1.18$ & NR & $6.85 \pm 1.65$ & NR & $.309 \pm 0.138$ & $144.0 \pm 12.8$ \\
\hline$Z$-value & $6 / 12 / 96$ & .61 & $\mathrm{NC}$ & .27 & $\mathrm{NC}$ & 1.19 & .35 \\
\hline NRF-10 & $9 / 4 / 96$ & $5.13 \pm 1.52$ & NR & $8.82 \pm 1.89$ & NR & $-.111 \pm 0.098$ & $144.0 \pm 12.8$ \\
\hline \multirow[t]{2}{*}{ NRF-11 } & $1 / 18 / 96$ & $1.96 \pm 0.66$ & $2.78 \pm 0.94$ & $4.62 \pm 0.72$ & $3.44 \pm 0.65$ & $-.106 \pm 0.140$ & $342.4 \pm 16$ \\
\hline & $3 / 25 / 96$ & $3.47 \pm 1.36$ & $8.68 \pm 3.46$ & $6.98 \pm 1.70$ & $3.82 \pm 0.84$ & $.031 \pm 0.132$ & $281.6 \pm 16$ \\
\hline QAS-49 & $3 / 25 / 96$ & $3.46 \pm 1.36$ & $8.61 \pm 3.42$ & $11.8 \pm 2.24$ & $5.87 \pm 0.88$ & $.188 \pm 0.144$ & $320.0 \pm 16$ \\
\hline Z-value & $3 / 25 / 96$ & .01 & .01 & 1.71 & $2.32(\mathrm{~N})$ & .80 & 1.70 \\
\hline \multirow[t]{2}{*}{ NRF-11 } & $6 / 12 / 96$ & $6.58 \pm 1.64$ & NR & $8.03 \pm 2.09$ & $\mathrm{NR}$ & $.075 \pm 0.118$ & $323.2 \pm 12.8$ \\
\hline & $9 / 5 / 96$ & $2.88 \pm 1.23$ & NR & $7.87 \pm 2.09$ & NR & $.043 \pm 0.114$ & $297.6 \pm 12.8$ \\
\hline \multirow[t]{2}{*}{ NRF-12 } & $1 / 22 / 96$ & $3.93 \pm 1.17$ & $5.09 \pm 1.52$ & $4.32 \pm 0.70$ & $3.17 \pm 0.441$ & $-.00438 \pm 0.14$ & $67.2 \pm 12.8$ \\
\hline & $3 / 20 / 96$ & $1.37 \pm 1.14$ & $3.55 \pm 2.96$ & $7.53 \pm 1.92$ & $3.83 \pm 0.88$ & $.162 \pm 0.131$ & $41.6 \pm 12.8$ \\
\hline
\end{tabular}


Table 6. Concentrations of gross alpha-particle radioactivity, gross beta-particle radioactivity, strontium-90, and tritium in water, Naval Reactors Facility and vicinity-Continued

\begin{tabular}{|c|c|c|c|c|c|c|c|}
\hline \multirow[b]{2}{*}{ Sample identifier } & \multirow{2}{*}{$\begin{array}{l}\text { Date sampled } \\
\qquad(\mathrm{m} / \mathrm{d} / \mathrm{y})\end{array}$} & \multicolumn{2}{|c|}{ Gross alpha-particle radioactivity } & \multicolumn{2}{|c|}{ Gross beta-particle radioactivity } & \multirow{2}{*}{$\begin{array}{l}\text { Strontium-90 } \\
(\mathrm{pCi} / \mathrm{L})\end{array}$} & \multirow{2}{*}{$\begin{array}{l}\text { Tritium } \\
(\mathrm{pCi} / \mathrm{L})\end{array}$} \\
\hline & & $\begin{array}{l}\text { as Thorium-230 } \\
(\mathrm{pCi} / \mathrm{L})\end{array}$ & $\begin{array}{l}\text { as Uranium } \\
(\mu \mathrm{g} / \mathrm{L})\end{array}$ & $\begin{array}{l}\text { as Cesium-137 } \\
(\mathrm{pCi} / \mathrm{L})\end{array}$ & $\begin{array}{c}\text { as } \mathrm{Sr}^{90} / \mathrm{Y}^{90} \\
(\mathrm{pCi} / \mathrm{L})\end{array}$ & & \\
\hline \multirow[t]{2}{*}{ NRF-12 - Cont. } & $6 / 12 / 96$ & $2.00 \pm 1.05$ & NR & $10.1 \pm 2.33$ & NR & $.253 \pm 0.152$ & $54.4 \pm 12.8$ \\
\hline & $9 / 5 / 96$ & $3.32 \pm 1.34$ & NR & $9.30 \pm 2.04$ & NR & $.077 \pm 0.110$ & $76.8 \pm 12.8$ \\
\hline \multirow[t]{3}{*}{ NRF-13 } & $1 / 22 / 96$ & $2.62 \pm 0.80$ & $4.09 \pm 1.24$ & $6.20 \pm 0.79$ & $4.61 \pm 0.482$ & $-.0604 \pm 0.135$ & $48.0 \pm 12.8$ \\
\hline & $3 / 20 / 96$ & $2.10 \pm 1.08$ & $4.39 \pm 2.26$ & $12.7 \pm 1.95$ & $6.67 \pm 0.70$ & $.201 \pm 0.112$ & $41.6 \pm 12.8$ \\
\hline & $6 / 13 / 96$ & $3.99 \pm 1.21$ & NR & $9.75 \pm 1.88$ & NR & $.008 \pm 0.086$ & $28.8 \pm 12.8$ \\
\hline QAS-51 & $6 / 13 / 96$ & $2.29 \pm 1.00$ & NR & $10.3 \pm 1.74$ & NR & $.075 \pm 0.108$ & $32.0 \pm 12.8$ \\
\hline Z-value & $6 / 13 / 96$ & 1.08 & $\mathrm{NC}$ & .21 & $\mathrm{NC}$ & .49 & .18 \\
\hline NRF-13 & $9 / 5 / 96$ & $2.09 \pm 1.12$ & NR & $13.5 \pm 2.16$ & NR & $.026 \pm 0.098$ & $48.0 \pm 12.8$ \\
\hline \multirow[t]{4}{*}{ USGS 12} & $1 / 16 / 96$ & $4.18 \pm 1.06$ & $5.63 \pm 1.44$ & $4.29 \pm 0.70$ & $3.16 \pm 0.468$ & $-.00485 \pm 0.105$ & $60.8 \pm 12.8$ \\
\hline & $3 / 21 / 96$ & $1.69 \pm 1.06$ & $3.71 \pm 2.34$ & $7.45 \pm 1.80$ & $3.18 \pm 0.66$ & $.041 \pm 0.119$ & $64.0 \pm 12.8$ \\
\hline & $6 / 10 / 96$ & $.32 \pm 0.80$ & NR & $6.71 \pm 2.24$ & NR & $.019 \pm 0.104$ & $60.8 \pm 12.8$ \\
\hline & $9 / 3 / 96$ & $2.52 \pm 1.24$ & NR & $7.02 \pm 2.12$ & NR & $.053 \pm 0.110$ & $48.0 \pm 12.8$ \\
\hline \multirow[t]{4}{*}{ USGS 97} & $1 / 17 / 96$ & $3.74 \pm 1.00$ & $5.28 \pm 1.42$ & $3.23 \pm 0.59$ & $2.37 \pm 0.52$ & $-.0691 \pm 0.13$ & $73.6 \pm 12.8$ \\
\hline & $3 / 25 / 96$ & $2.07 \pm 1.16$ & $4.94 \pm 2.80$ & $6.47 \pm 1.67$ & $3.29 \pm 0.76$ & $.066 \pm 0.132$ & $19.2 \pm 12.8$ \\
\hline & $6 / 11 / 96$ & $3.81 \pm 1.32$ & NR & $6.97 \pm 2.25$ & NR & $.086 \pm 0.116$ & $51.2 \pm 12.8$ \\
\hline & $9 / 4 / 96$ & $3.29 \pm 1.32$ & NR & $7.26 \pm 1.74$ & NR & $.132 \pm 0.109$ & $60.8 \pm 12.8$ \\
\hline \multirow[t]{2}{*}{ USGS 98} & $1 / 17 / 96$ & $2.15 \pm 0.67$ & $2.80 \pm 0.88$ & $3.23 \pm 0.481$ & $2.45 \pm 0.364$ & $-.0115 \pm 0.11$ & $16.0 \pm 12.8$ \\
\hline & $3 / 21 / 96$ & $1.17 \pm 0.97$ & $2.47 \pm 2.05$ & $7.10 \pm 1.50$ & $3.52 \pm 0.62$ & $.171 \pm 0.117$ & $6.4 \pm 12.8$ \\
\hline
\end{tabular}


Table 6. Concentrations of gross alpha-particle radioactivity, gross beta-particle radioactivity, strontium-90, and tritium in water, Naval Reactors Facility and vicinity-Continued

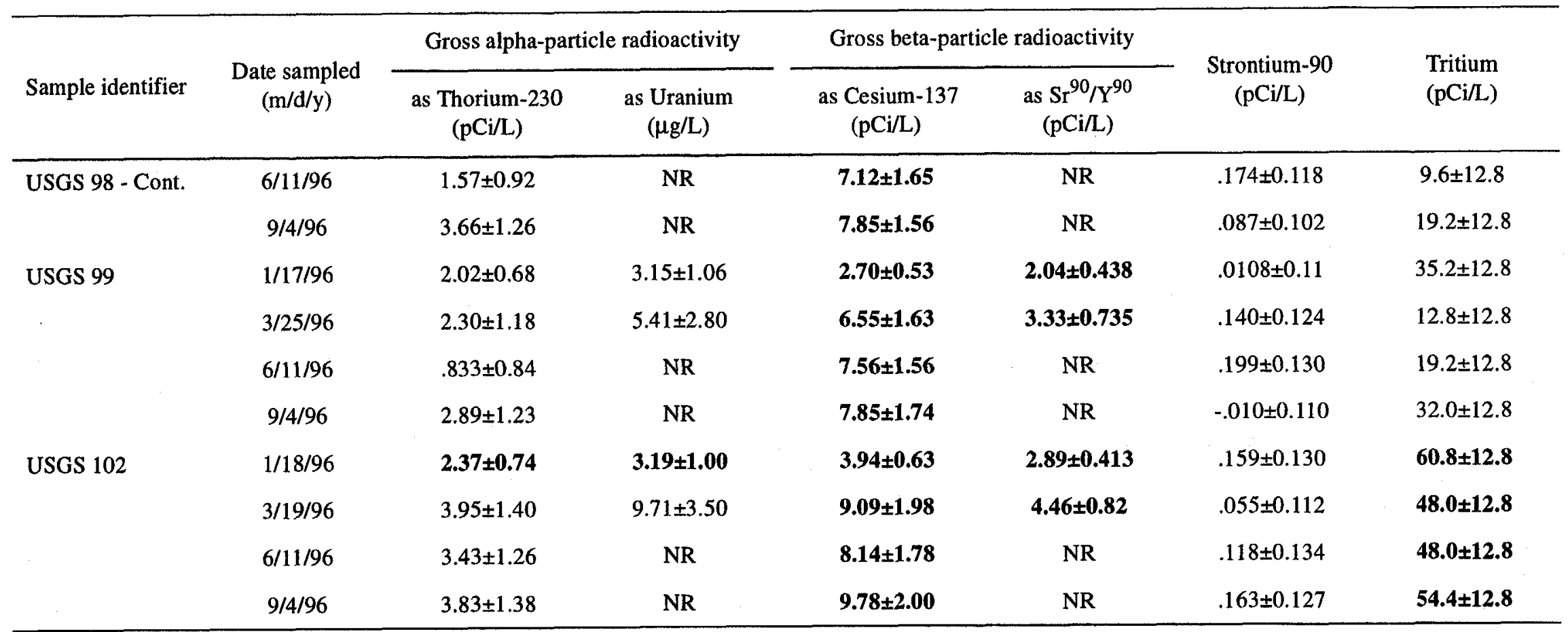




\section{Table 7. Concentrations of selected isotopes from analysis by gamma spectrometry, Naval Reactors Facility and vicinity}

[Analyses were performed by the U.S. Geological Survey National Water Quality Laboratory using gamma spectrometry. Analytical results and uncertainties - for example, $1.39 \pm 0.39$-are in picocuries per liter (pCi/L). Analytical uncertainties are reported as 1s. Concentrations that meet or exceed the reporting level of 3 times the $1 \mathrm{~s}$ value are shown in boldface type. Sample identifier: see figure 2 for location of sites. Date sampled: $(\mathrm{m} / \mathrm{d} / \mathrm{y})$, month/day/year. QAS indicates quality assurance sample: 52 is a field-blank; others are replicates. Z-values associated with QA replicates were calculated using equation $1 ;(\mathrm{N})$ indicates that $\mathrm{Z}$-value is greater than 1.96 and that the two results are not equivalent at the 95-percent confidence limit. NC, value was not calculated; NR, analysis was not reported. The sample collected from well NRF-13 on $6 / 13 / 96$ contained $0.641 \pm 0.170 \mathrm{pCi} / \mathrm{L}$ of strontium-85. Strontium-85 was not reported in the replicate sample (QAS-51). The calculated Z-value for this sample pair was 3.77 , which indicates that the two results were not statistically equivalent at the 95-percent confidence limit]

\begin{tabular}{|c|c|c|c|c|}
\hline \multirow[b]{2}{*}{ Isotope } & \multicolumn{4}{|c|}{ Sample identifier and date sampled $(\mathrm{m} / \mathrm{d} / \mathrm{y})$} \\
\hline & $\begin{array}{l}\text { QAS-52 } \\
9 / 3 / 96\end{array}$ & $\begin{array}{l}\text { NRF-6 } \\
\text { 1/16/96 }\end{array}$ & $\begin{array}{l}\text { NRF-6 } \\
3 / 19 / 96\end{array}$ & $\begin{array}{l}\text { NRF-6 } \\
6 / 10 / 96\end{array}$ \\
\hline Actinium-228 & NR & $1.39 \pm 0.39$ & $1.83 \pm 0.43$ & NR \\
\hline Bismuth-214 & $0.845 \pm 0.215$ & $.841 \pm 0.215$ & $.864 \pm 0.215$ & $0.0739 \pm 0.22$ \\
\hline Cesium-134 & $-.0303 \pm 0.095$ & $-.183 \pm 0.095$ & $-.0142 \pm 0.095$ & $-.0132 \pm 0.105$ \\
\hline Cesium-137 & $-.101 \pm 0.105$ & $.0911 \pm 0.10$ & $.183 \pm 0.09$ & $.077 \pm 0.10$ \\
\hline Chromium-51 & $1.20 \pm 0.95$ & $-1.14 \pm 0.135$ & $-1.04 \pm 1.5$ & $.830 \pm 1.3$ \\
\hline Cobalt- 60 & $.0705 \pm 0.095$ & $-.00287 \pm 0.095$ & $.182 \pm 0.095$ & $-.146 \pm 0.10$ \\
\hline Lead-212 & $.118 \pm 0.305$ & $.695 \pm 0.145$ & $.199 \pm 0.285$ & $.397 \pm 0.15$ \\
\hline Lead-214 & $.0573 \pm 0.19$ & $.439 \pm 0.18$ & $.360 \pm 0.20$ & $.416 \pm 0.18$ \\
\hline Potassium-40 & $14.1 \pm 1.7$ & $24.8 \pm 2.2$ & $16.6 \pm 3.25$ & $.257 \pm 3.5$ \\
\hline Radium-223 & $.554 \pm 0.45$ & $.876 \pm 0.435$ & $-.504 \pm 0.445$ & $.0555 \pm 0.45$ \\
\hline Radium-224 & NR & $.715 \pm 0.15$ & $.926 \pm 0.165$ & NR \\
\hline Radium-226 & $.845 \pm 0.215$ & $.841 \pm 0.215$ & $.864 \pm 0.215$ & $.0739 \pm 0.22$ \\
\hline Radium-228 & $.720 \pm 0.395$ & $1.4 \pm 0.395$ & $1.85 \pm 0.435$ & $.0261 \pm 0.41$ \\
\hline Ruthenium-106 & $-1.80 \pm 0.9$ & $1.95 \pm 0.9$ & $-1.16 \pm 0.95$ & $.206 \pm 0.95$ \\
\hline Thallium-208 & $.396 \pm 0.105$ & $.542 \pm 0.105$ & $.510 \pm 0.105$ & $.160 \pm 0.10$ \\
\hline Thorium-228 & $1.54 \pm 0.495$ & $1.55 \pm 0.305$ & $1.47 \pm 0.295$ & $.459 \pm 0.29$ \\
\hline Thorium-232 & NR & $1.19 \pm 0.55$ & $1.86 \pm 0.60$ & NR \\
\hline Thorium-234 & $38.2 \pm 18.5$ & $40.6 \pm 16$ & $51.5 \pm 18$ & $39.9 \pm 17$ \\
\hline Uranium-234 & $.454 \pm 0.33$ & $.407 \pm 0.315$ & $.436 \pm 0.340$ & $-.322 \pm 0.335$ \\
\hline Uranium-235 & $.911 \pm 0.425$ & $.206 \pm 0.405$ & $.659 \pm 0.425$ & $.216 \pm 0.43$ \\
\hline Uranium-238 & $.0573 \pm 0.19$ & $.439 \pm 0.18$ & $.360 \pm 0.200$ & $.416 \pm 0.18$ \\
\hline Zinc-65 & $-.159 \pm 0.22$ & $-.0739 \pm 0.22$ & $-.581 \pm 0.225$ & $.130 \pm 0.225$ \\
\hline
\end{tabular}


Table 7. Concentrations of selected isotopes from analysis by gamma spectrometry, Naval Reactors Facility and vicinity-Continued

\begin{tabular}{|c|c|c|c|c|}
\hline \multirow[b]{2}{*}{ Isotope } & \multicolumn{4}{|c|}{ Sample identifier and date sampled $(\mathrm{m} / \mathrm{d} / \mathbf{y})$} \\
\hline & $\begin{array}{c}\text { NRF-6 } \\
\text { 9/5/96 }\end{array}$ & $\begin{array}{l}\text { NRF-7 } \\
\text { 1/16/96 }\end{array}$ & $\begin{array}{l}\text { NRF-7 } \\
\text { 3/19/96 }\end{array}$ & $\begin{array}{l}\text { NRF-7 } \\
\text { 6/10/96 }\end{array}$ \\
\hline Actinium-228 & NR & $1.90 \pm 0.425$ & $1.01 \pm 0.40$ & NR \\
\hline Bismuth-214 & $.808 \pm 0.215$ & $.495 \pm 0.20$ & $.624 \pm 0.205$ & $1.28 \pm 0.245$ \\
\hline Cesium-134 & $-.101 \pm 0.095$ & $.00633 \pm 0.095$ & $-.074 \pm 0.10$ & $.0232 \pm 0.11$ \\
\hline Cesium-137 & $-.0354 \pm 0.105$ & $-.233 \pm 0.11$ & $.210 \pm 0.10$ & $-.242 \pm 0.12$ \\
\hline Chromium-51 & $.513 \pm 1.1$ & $1.37 \pm 1.50$ & $1.57 \pm 1.5$ & $1.18 \pm 1.55$ \\
\hline Cobalt- 60 & $-.0997 \pm 0.115$ & $.219 \pm 0.110$ & $-.00993 \pm 0.105$ & $.0516 \pm 0.125$ \\
\hline Lead-212 & $1.24 \pm 0.175$ & $.0142 \pm 0.275$ & $.282 \pm 0.255$ & $.561 \pm 0.175$ \\
\hline Lead-214 & $.836 \pm 0.21$ & $.665 \pm 0.19$ & $.208 \pm 0.195$ & $.640 \pm 0.215$ \\
\hline Potassium-40 & $.774 \pm 3.6$ & $27.7 \pm 2.3$ & $1.65 \pm 2.90$ & $58.9 \pm 3.85$ \\
\hline Radium-223 & $1.22 \pm 0.495$ & $-.590 \pm 0.465$ & $.103 \pm 0.465$ & $.0946 \pm 0.55$ \\
\hline Radium-224 & NR & $.746 \pm 0.165$ & $.291 \pm 0.265$ & NR \\
\hline Radium-226 & $.808 \pm 0.215$ & $.495 \pm 0.20$ & $.624 \pm 0.205$ & $1.28 \pm 0.245$ \\
\hline Radium-228 & $2.13 \pm 0.425$ & $1.92 \pm 0.43$ & $1.02 \pm 0.405$ & $1.91 \pm 0.465$ \\
\hline Ruthenium-106 & $1.43 \pm 0.9$ & $-.963 \pm 0.95$ & $.966 \pm 0.95$ & $-.428 \pm 1.05$ \\
\hline Thallium-208 & $.554 \pm 0.11$ & $.401 \pm 0.11$ & $.239 \pm 0.105$ & $.437 \pm 0.125$ \\
\hline Thorium-228 & $1.56 \pm 0.305$ & $1.15 \pm 0.32$ & $.298 \pm 0.485$ & $1.25 \pm 0.355$ \\
\hline Thorium-232 & NR & $1.04 \pm 0.65$ & $1.98 \pm 0.60$ & NR \\
\hline Thorium-234 & $28.9 \pm 17$ & $22.5 \pm 19$ & $11.6 \pm 17.5$ & $57.9 \pm 19$ \\
\hline Uranium-234 & $.622 \pm 0.365$ & $.292 \pm 0.355$ & $-.0418 \pm 0.35$ & $-.918 \pm 0.395$ \\
\hline Uranium-235 & $1.09 \pm 0.5$ & $1.78 \pm 0.460$ & $.790 \pm 0.42$ & $1.06 \pm 0.49$ \\
\hline Uranium-238 & $.836 \pm 0.21$ & $.665 \pm 0.190$ & $.208 \pm 0.195$ & $.640 \pm 0.215$ \\
\hline Zinc-65 & $.473 \pm 0.225$ & $-.160 \pm 0.240$ & $.279 \pm 0.24$ & $.0652 \pm 0.31$ \\
\hline
\end{tabular}


Table 7. Concentrations of selected isotopes from analysis by gamma spectrometry, Naval Reactors Facility and vicinity-Continued

\begin{tabular}{|c|c|c|c|c|}
\hline \multirow[b]{2}{*}{ Isotope } & \multicolumn{4}{|c|}{ Sample identifier and date sampled $(m / d / y)$} \\
\hline & $\begin{array}{l}\text { NRF-7 } \\
\text { 9/3/96 }\end{array}$ & $\begin{array}{l}\text { NRF-8 } \\
1 / 17 / 96\end{array}$ & $\begin{array}{l}\text { QAS-46 } \\
1 / 17 / 96\end{array}$ & $\begin{array}{l}\text { Z-value } \\
\text { 1/17/96 }\end{array}$ \\
\hline Actinium-228 & NR & $1.46 \pm 0.385$ & $.605 \pm 0.39$ & 1.56 \\
\hline Bismuth-214 & $.944 \pm 0.21$ & $.752 \pm 0.21$ & $.988 \pm 0.205$ & .80 \\
\hline Cesium-134 & $.0368 \pm 0.095$ & $-.044 \pm 0.095$ & $-.100 \pm 0.09$ & .43 \\
\hline Cesium-137 & $.0974 \pm 0.09$ & $-.124 \pm 0.105$ & $-.0937 \pm 0.10$ & .21 \\
\hline Chromium-51 & $-.729 \pm 0.85$ & $1.42 \pm 1.2$ & $-.507 \pm 1.25$ & 1.11 \\
\hline Cobalt- 60 & $.0762 \pm 0.105$ & $.0922 \pm 0.10$ & $.0043 \pm 0.11$ & .59 \\
\hline Lead-212 & $.544 \pm 0.285$ & $.919 \pm 0.145$ & $.175 \pm 0.27$ & $2.43(\mathrm{~N})$ \\
\hline Lead-214 & $.389 \pm 0.175$ & $.336 \pm 0.175$ & $1.02 \pm 0.195$ & $2.61(\mathrm{~N})$ \\
\hline Potassium-40 & $.196 \pm 3.25$ & $31.5 \pm 2.6$ & $19.8 \pm 1.95$ & $3.60(\mathrm{~N})$ \\
\hline Radium-223 & $-.429 \pm 0.405$ & $-.162 \pm 0.415$ & $-.108 \pm 0.43$ & .03 \\
\hline Radium-224 & NR & $.946 \pm 0.145$ & $.745 \pm 0.145$ & .98 \\
\hline Radium-226 & $.944 \pm 0.210$ & $.752 \pm 0.21$ & $.988 \pm 0.205$ & .80 \\
\hline Radium-228 & $1.87 \pm 0.425$ & $1.47 \pm 0.39$ & $.611 \pm 0.395$ & 1.55 \\
\hline Ruthenium-106 & $-1.65 \pm 0.90$ & $-.697 \pm 0.85$ & $.772 \pm 0.85$ & 1.22 \\
\hline Thallium-208 & $.538 \pm 0.195$ & $.395 \pm 0.11$ & $.344 \pm 0.11$ & .33 \\
\hline Thorium-228 & $1.52 \pm 0.55$ & $1.13 \pm 0.315$ & $.986 \pm 0.31$ & .33 \\
\hline Thorium-232 & NR & $.680 \pm 0.55$ & $.679 \pm 0.6$ & .00 \\
\hline Thorium-234 & $50.2 \pm 17$ & $25.7 \pm 17$ & $43.5 \pm 16.5$ & .75 \\
\hline Uranium-234 & $.579 \pm 0.295$ & $-.124 \pm 0.31$ & $.277 \pm 0.33$ & .89 \\
\hline Uranium-235 & $1.15 \pm 0.39$ & $1.53 \pm 0.38$ & $.443 \pm 0.405$ & 1.96 \\
\hline Uranium-238 & $.389 \pm 0.175$ & $0.336 \pm 0.175$ & $1.02 \pm 0.195$ & $2.61(\mathrm{~N})$ \\
\hline Zinc-65 & $.185 \pm 0.22$ & $.0697 \pm 0.215$ & $.268 \pm 0.20$ & .68 \\
\hline
\end{tabular}


Table 7. Concentrations of selected isotopes from analysis by gamma spectrometry, Naval Reactors Facility and vicinity-Continued

\begin{tabular}{|c|c|c|c|c|}
\hline \multirow[b]{2}{*}{ Isotope } & \multicolumn{4}{|c|}{ Sample identifier and date sampled $(\mathrm{m} / \mathrm{d} / \mathbf{y})$} \\
\hline & $\begin{array}{l}\text { NRF-8 } \\
3 / 25 / 96\end{array}$ & $\begin{array}{l}\text { NRF-8 } \\
6 / 11 / 96\end{array}$ & $\begin{array}{l}\text { NRF-8 } \\
9 / 4 / 96\end{array}$ & $\begin{array}{l}\text { NRF-9 } \\
\text { 1/18/96 }\end{array}$ \\
\hline Actinium-228 & $.920 \pm 0.41$ & NR & NR & $.518 \pm 0.405$ \\
\hline Bismuth-214 & $.763 \pm 0.215$ & $.353 \pm 0.20$ & $.664 \pm 0.235$ & $1.14 \pm 0.225$ \\
\hline Cesium-134 & $-.136 \pm 0.105$ & $.106 \pm 0.095$ & $-.0723 \pm 0.11$ & $-.0933 \pm 0.10$ \\
\hline Cesium-137 & $.156 \pm 0.10$ & $.139 \pm 0.105$ & $.0906 \pm 0.115$ & $.112 \pm 0.105$ \\
\hline Chromium-51 & $.158 \pm 1.55$ & $1.88 \pm 1.4$ & $.268 \pm 1.2$ & $-3.45 \pm 1.4$ \\
\hline Cobalt-60 & $.330 \pm 0.105$ & $.234 \pm 0.10$ & $.138 \pm 0.12$ & $.238 \pm 0.10$ \\
\hline Lead-212 & $.0245 \pm 0.245$ & $.741 \pm 0.155$ & $.568 \pm 0.15$ & $.672 \pm 0.14$ \\
\hline Lead-214 & $.481 \pm 0.20$ & $.279 \pm 0.185$ & $.370 \pm 0.215$ & $.646 \pm 0.19$ \\
\hline Potassium-40 & $4.09 \pm 3.3$ & $4.87 \pm 3.2$ & $57.0 \pm 3.75$ & $38.0 \pm 2.75$ \\
\hline Radium-223 & $.874 \pm 0.46$ & $.230 \pm 0.475$ & $.0436 \pm 0.55$ & $.815 \pm 0.415$ \\
\hline Radium-224 & $.0253 \pm 0.255$ & NR & NR & $.691 \pm 0.145$ \\
\hline Radium-226 & $.763 \pm 0.215$ & $.353 \pm 0.20$ & $.664 \pm 0.235$ & $1.01 \pm 0.22$ \\
\hline Radium-228 & $.929 \pm 0.415$ & $1.24 \pm 0.395$ & $1.63 \pm 0.44$ & $.523 \pm 0.41$ \\
\hline Ruthenium-106 & $.817 \pm 0.95$ & $-.743 \pm 0.85$ & $1.12 \pm 1.05$ & $.139 \pm 0.9$ \\
\hline Thallium-208 & $.373 \pm 0.135$ & $.394 \pm 0.105$ & $.352 \pm 0.12$ & $.129 \pm 0.10$ \\
\hline Thorium-228 & $1.07 \pm 0.38$ & $1.13 \pm 0.305$ & $.996 \pm 0.345$ & $.369 \pm 0.29$ \\
\hline Thorium-232 & $2.38 \pm 0.65$ & NR & NR & $-.195 \pm 0.6$ \\
\hline Thorium-234 & $32.3 \pm 17.5$ & $16.5 \pm 17$ & $-31.8 \pm 21.5$ & $39.2 \pm 18$ \\
\hline Uranium-234 & $.466 \pm 0.34$ & $-.0119 \pm 0.34$ & $.0660 \pm 0.38$ & $1.17 \pm 0.33$ \\
\hline Uranium-235 & $.689 \pm 0.47$ & $.456 \pm 0.425$ & $.234 \pm 0.495$ & $.944 \pm 0.425$ \\
\hline Uranium-238 & $.481 \pm 0.20$ & $.279 \pm 0.185$ & $.370 \pm 0.215$ & $.646 \pm 0.19$ \\
\hline Zinc-65 & $-.0838 \pm 0.235$ & $.128 \pm 0.215$ & $-.385 \pm 0.27$ & $.121 \pm 0.215$ \\
\hline
\end{tabular}


Table 7. Concentrations of selected isotopes from analysis by gamma spectrometry, Naval Reactors Facility and vicinity-Continued

\begin{tabular}{|c|c|c|c|c|}
\hline \multirow[b]{2}{*}{ Isotope } & \multicolumn{4}{|c|}{ Sample identifier and date sampled $(m / d / y)$} \\
\hline & $\begin{array}{l}\text { NRF-9 } \\
3 / 26 / 96\end{array}$ & $\begin{array}{l}\text { NRF-9 } \\
\text { 6/11/96 }\end{array}$ & $\begin{array}{l}\text { NRF-9 } \\
\text { 9/4/96 }\end{array}$ & $\begin{array}{c}\text { NRF-10 } \\
5 / 8 / 96\end{array}$ \\
\hline Actinium-228 & $1.75 \pm 0.38$ & NR & NR & $2.27 \pm 0.49$ \\
\hline Bismuth-214 & $.903 \pm 0.195$ & $1.57 \pm 0.245$ & $1.32 \pm 0.23$ & $.906 \pm 0.24$ \\
\hline Cesium-134 & $.0872 \pm 0.09$ & $-.188 \pm 0.105$ & $-.0340 \pm 0.10$ & $.103 \pm 0.11$ \\
\hline Cesium-137 & $-.135 \pm 0.095$ & $-.194 \pm 0.11$ & $-.0893 \pm 0.11$ & $-.274 \pm 0.125$ \\
\hline Chromium-51 & $1.28 \pm 0.125$ & $.00828 \pm 1.65$ & $3.39 \pm 1.15$ & $1.46 \pm 1.85$ \\
\hline Cobalt-60 & $.217 \pm 0.095$ & $-.0543 \pm 0.12$ & $.254 \pm 0.11$ & $.111 \pm 0.135$ \\
\hline Lead-212 & $.558 \pm 0.245$ & $.00403 \pm 0.29$ & $1.13 \pm 0.175$ & $.00892 \pm 0.25$ \\
\hline Lead-214 & $.201 \pm 0.17$ & $.833 \pm 0.225$ & $.740 \pm 0.22$ & $.0911 \pm 0.43$ \\
\hline Potassium-40 & $50.2 \pm 3.3$ & $5.15 \pm 3.75$ & $.439 \pm 3.6$ & $60.5 \pm 3.9$ \\
\hline Radium-223 & $-.564 \pm 0.395$ & $.313 \pm 0.55$ & $-.0364 \pm 0.495$ & $-.0509 \pm 0.5$ \\
\hline Radium-224 & $1.25 \pm 0.15$ & $.004 \pm 0.3$ & NR & $.727 \pm 0.16$ \\
\hline Radium-226 & $.903 \pm 0.195$ & $1.57 \pm 0.245$ & $1.32 \pm 0.23$ & $.906 \pm 0.24$ \\
\hline Radium-228 & $1.76 \pm 0.38$ & $2.58 \pm 0.435$ & $2.16 \pm 0.44$ & $2.30 \pm 0.495$ \\
\hline Ruthenium-106 & $1.16 \pm 0.85$ & $-.537 \pm 1.0$ & $-1.35 \pm 0.95$ & $1.93 \pm 1.1$ \\
\hline Thallium-208 & $.139 \pm 0.10$ & $.714 \pm 0.12$ & $.737 \pm 0.115$ & $.563 \pm 0.12$ \\
\hline Thorium-228 & $.399 \pm 0.29$ & $2.55 \pm 0.55$ & $2.08 \pm 0.32$ & $1.62 \pm 0.35$ \\
\hline Thorium-232 & $.208 \pm 0.55$ & NR & NR & $.399 \pm 0.7$ \\
\hline Thorium-234 & $9.27 \pm 17.5$ & $81.1 \pm 18$ & $-9.49 \pm 18.5$ & $5.92 \pm 20.5$ \\
\hline Uranium-234 & $.535 \pm 0.315$ & $.705 \pm 0.385$ & $1.18 \pm 0.37$ & $1.63 \pm 0.395$ \\
\hline Uranium-235 & $.597 \pm 0.40$ & $1.46 \pm 0.55$ & $1.41 \pm 0.55$ & $.372 \pm 0.495$ \\
\hline Uranium-238 & $.201 \pm 0.17$ & $.833 \pm 0.225$ & $.740 \pm 0.22$ & NR \\
\hline Zinc-65 & $.229 \pm 0.22$ & $-.00761 \pm 0.26$ & $-.620 \pm 0.235$ & $.106 \pm 0.27$ \\
\hline
\end{tabular}


Table 7. Concentrations of selected isotopes from analysis by gamma spectrometry, Naval Reactors Facility and vicinity-Continued

\begin{tabular}{|c|c|c|c|c|}
\hline \multirow[b]{2}{*}{ Isotope } & \multicolumn{4}{|c|}{ Sample identifier and date sampled $(\mathrm{m} / \mathrm{d} / \mathrm{y})$} \\
\hline & $\begin{array}{c}\text { NRF-10 } \\
6 / 12 / 96\end{array}$ & $\begin{array}{l}\text { QAS-50 } \\
6 / 12 / 96\end{array}$ & $\begin{array}{l}\text { Z-value } \\
6 / 12 / 96\end{array}$ & $\begin{array}{c}\text { NRF-10 } \\
9 / 4 / 96\end{array}$ \\
\hline Actinium-228 & NR & NR & NC & NR \\
\hline Bismuth-214 & $.291 \pm 0.20$ & $.540 \pm 0.21$ & .86 & $.967 \pm 0.205$ \\
\hline Cesium-134 & $.0801 \pm 0.09$ & $.0602 \pm 0.10$ & .15 & $.0373 \pm 0.085$ \\
\hline Cesium-137 & $-.194 \pm 0.105$ & $.0105 \pm 0.105$ & 1.38 & $.153 \pm 0.085$ \\
\hline Chromium-51 & $-2.10 \pm 1.35$ & $-.0587 \pm 1.6$ & .98 & $.422 \pm 0.9$ \\
\hline Cobalt- 60 & $.136 \pm 0.115$ & $.0526 \pm 0.105$ & .54 & $.0589 \pm 0.11$ \\
\hline Lead-212 & $.0565 \pm 0.245$ & $.0418 \pm 0.245$ & .04 & $.977 \pm 0.14$ \\
\hline Lead-214 & $.242 \pm 0.175$ & $.448 \pm 0.195$ & .79 & $.741 \pm 0.185$ \\
\hline Potassium-40 & $27.8 \pm 2.25$ & $3.56 \pm 2.8$ & $6.75(\mathrm{~N})$ & $45.6 \pm 3.2$ \\
\hline Radium-223 & $.0340 \pm 0.405$ & $-.523 \pm 0.465$ & .90 & $.197 \pm 0.43$ \\
\hline Radium-224 & NR & NR & $\mathrm{NC}$ & NR \\
\hline Radium-226 & $.291 \pm 0.20$ & $.540 \pm 0.21$ & .86 & $.967 \pm 0.205$ \\
\hline Radium-228 & $1.64 \pm 0.385$ & $1.69 \pm 0.36$ & .09 & $2.68 \pm 0.39$ \\
\hline Ruthenium-106 & $1.42 \pm 0.85$ & $.339 \pm 1.0$ & .82 & $-.628 \pm 0.8$ \\
\hline Thallium-208 & $.305 \pm 0.105$ & $.288 \pm 0.105$ & .11 & $.439 \pm 0.105$ \\
\hline Thorium-228 & $.873 \pm 0.30$ & $.830 \pm 0.295$ & .10 & $1.24 \pm 0.30$ \\
\hline Thorium-232 & NR & NR & $\mathrm{NC}$ & NR \\
\hline Thorium-234 & $-5.18 \pm 18.5$ & $17.1 \pm 18.5$ & .85 & $-4.29 \pm 18$ \\
\hline Uranium-234 & $-.332 \pm 0.325$ & $1.30 \pm 0.335$ & $3.50(\mathrm{~N})$ & $-.104 \pm 0.325$ \\
\hline Uranium-235 & $1.23 \pm 0.39$ & $.560 \pm 0.5$ & 1.06 & $.336 \pm 0.425$ \\
\hline Uranium-238 & $.242 \pm 0.175$ & $.448 \pm 0.195$ & .79 & $.741 \pm 0.185$ \\
\hline Zinc-65 & $-.825 \pm 0.24$ & $.0920 \pm 0.235$ & $2.73(\mathrm{~N})$ & $.357 \pm 0.22$ \\
\hline
\end{tabular}


Table 7. Concentrations of selected isotopes from analysis by gamma spectrometry, Naval Reactors Facility and vicinity-Continued

\begin{tabular}{|c|c|c|c|c|}
\hline \multirow[b]{2}{*}{ Isotope } & \multicolumn{4}{|c|}{ Sample identifier and date sampled $(\mathrm{m} / \mathrm{d} / \mathrm{y})$} \\
\hline & $\begin{array}{l}\text { NRF-11 } \\
\text { V/18/96 }\end{array}$ & $\begin{array}{l}\text { NRF-11 } \\
3 / 25 / 96\end{array}$ & $\begin{array}{l}\text { QAS-49 } \\
\text { 3/25/96 }\end{array}$ & $\begin{array}{l}\text { Z-value } \\
3 / 25 / 96\end{array}$ \\
\hline Actinium-228 & $1.56 \pm 0.42$ & $2.01 \pm 0.405$ & $1.56 \pm 0.395$ & .80 \\
\hline Bismuth-214 & $.710 \pm 0.21$ & $.579 \pm 0.21$ & $-.189 \pm 0.215$ & $2.56(\mathrm{~N})$ \\
\hline Cesium-134 & $-.0104 \pm 0.09$ & $.0397 \pm 0.10$ & $.0528 \pm 0.10$ & .09 \\
\hline Cesium-137 & $.0875 \pm 0.105$ & $.0875 \pm 0.10$ & $-.134 \pm 0.105$ & 1.53 \\
\hline Chromium-51 & $-.646 \pm 1.2$ & $1.04 \pm 1.4$ & $.212 \pm 1.5$ & .40 \\
\hline Cobalt- 60 & $.770 \pm 0.13$ & $.398 \pm 0.135$ & $.675 \pm 0.18$ & 1.23 \\
\hline Lead-212 & $.0043 \pm 0.255$ & $.140 \pm 0.32$ & $.750 \pm 0.16$ & 1.71 \\
\hline Lead-214 & $.647 \pm 0.19$ & $.0036 \pm 0.195$ & $-.255 \pm 0.21$ & .90 \\
\hline Potassium-40 & $.885 \pm 3.7$ & $8.59 \pm 3.2$ & $3.73 \pm 3.0$ & 1.11 \\
\hline Radium-223 & $.0103 \pm 0.405$ & $.581 \pm 0.44$ & $-.531 \pm 0.485$ & 1.70 \\
\hline Radium-224 & $1.03 \pm 0.15$ & $.847 \pm 0.155$ & $.773 \pm 0.165$ & .33 \\
\hline Radium-226 & $.710 \pm 0.21$ & $.579 \pm 0.21$ & $-.189 \pm 0.215$ & $2.56(\mathrm{~N})$ \\
\hline Radium-228 & $1.57 \pm 0.42$ & $2.03 \pm 0.405$ & $1.58 \pm 0.40$ & .79 \\
\hline Ruthenium-106 & $-.180 \pm 0.85$ & $.133 \pm 0.95$ & $-1.44 \pm 1.0$ & 1.14 \\
\hline Thallium-208 & $.410 \pm 0.11$ & $.399 \pm 0.105$ & $.349 \pm 0.11$ & .33 \\
\hline Thorium-228 & $1.17 \pm 0.315$ & $1.14 \pm 0.305$ & $1.00 \pm 0.32$ & .32 \\
\hline Thorium-232 & $2.14 \pm 0.6$ & $1.15 \pm 0.6$ & $.177 \pm 0.65$ & 1.10 \\
\hline Thorium-234 & $55.2 \pm 19.0$ & $66.9 \pm 18.0$ & $57.5 \pm 19.0$ & .36 \\
\hline Uranium-234 & $.0824 \pm 0.31$ & $.330 \pm 0.33$ & $.305 \pm 0.35$ & .05 \\
\hline Uranium-235 & $.770 \pm 0.41$ & $.602 \pm 0.415$ & $1.34 \pm 0.47$ & 1.18 \\
\hline Uranium-238 & $.647 \pm 0.19$ & $.0036 \pm 0.195$ & $-.255 \pm 0.21$ & .90 \\
\hline Zinc-65 & $-.0849 \pm 0.21$ & $-.508 \pm 0.235$ & $-.403 \pm 0.265$ & .30 \\
\hline
\end{tabular}


Table 7. Concentrations of selected isotopes from analysis by gamma spectrometry, Naval Reactors Facility and vicinity-Continued

\begin{tabular}{|c|c|c|c|c|}
\hline \multirow[b]{2}{*}{ Isotope } & \multicolumn{4}{|c|}{ Sample identifier and date sampled $(\mathbf{m} / \mathbf{d} / \mathbf{y})$} \\
\hline & $\begin{array}{l}\text { NRF.11 } \\
\text { 6/12/96 }\end{array}$ & $\begin{array}{c}\text { NRF-11 } \\
9 / 5 / 96\end{array}$ & $\begin{array}{l}\text { NRF-12 } \\
1 / 22 / 96\end{array}$ & $\begin{array}{l}\text { NRF-12 } \\
3 / 20 / 96\end{array}$ \\
\hline Actinium-228 & NR & NR & $2.17 \pm 0.40$ & $.369 \pm 0.375$ \\
\hline Bismuth-214 & $.567 \pm 0.21$ & $1.22 \pm 0.22$ & $.637 \pm 0.21$ & $.357 \pm 0.205$ \\
\hline Cesium-134 & $-.057 \pm 0.105$ & $-.0452 \pm 0.095$ & $-.208 \pm 0.105$ & $-.0256 \pm 0.10$ \\
\hline Cesium-137 & $.0683 \pm 0.10$ & $.0573 \pm 0.11$ & $0 \pm 0.095$ & $.0473 \pm 0.105$ \\
\hline Chromium-51 & $-.558 \pm 1.45$ & $.335 \pm 1.15$ & $-.531 \pm 1.3$ & $.987 \pm 1.45$ \\
\hline Cobalt- 60 & $.769 \pm 0.195$ & $.478 \pm 0.13$ & $-.00367 \pm 0.105$ & $-.0638 \pm 0.11$ \\
\hline Lead-212 & $.643 \pm 0.145$ & $1.26 \pm 0.18$ & $.714 \pm 0.135$ & $.127 \pm 0.26$ \\
\hline Lead-214 & $.158 \pm 0.19$ & $.708 \pm 0.22$ & $.594 \pm 0.19$ & $.362 \pm 0.195$ \\
\hline Potassium-40 & $.239 \pm 3.3$ & $3.87 \pm 3.5$ & $37.0 \pm 2.75$ & $14.2 \pm 1.7$ \\
\hline Radium-223 & $-.364 \pm 0.465$ & $.655 \pm 0.48$ & $.410 \pm 0.435$ & $-.737 \pm 0.47$ \\
\hline Radium-224 & NR & NR & $.735 \pm 0.14$ & $.550 \pm 0.16$ \\
\hline Radium-226 & $.567 \pm 0.21$ & $1.22 \pm 0.22$ & $.637 \pm 0.21$ & $.357 \pm 0.205$ \\
\hline Radium-228 & $1.20 \pm 0.39$ & $2.54 \pm 0.44$ & $2.19 \pm 0.405$ & $.373 \pm 0.38$ \\
\hline Ruthenium-106 & $1.46 \pm 0.9$ & $-.546 \pm 0.95$ & $.119 \pm 0.85$ & $.727 \pm 1.0$ \\
\hline Thallium-208 & $.0764 \pm 0.105$ & $.651 \pm 0.12$ & $.460 \pm 0.11$ & $.319 \pm 0.105$ \\
\hline Thorium-228 & $.219 \pm 0.30$ & $1.85 \pm 0.335$ & $1.32 \pm 0.31$ & $.914 \pm 0.30$ \\
\hline Thorium-232 & NR & NR & $.653 \pm 0.6$ & $-.690 \pm 0.65$ \\
\hline Thorium-234 & $48.4 \pm 18.0$ & $56.6 \pm 17.5$ & $15.1 \pm 18.0$ & $45.0 \pm 18.0$ \\
\hline Uranium-234 & $.388 \pm 0.335$ & $.128 \pm 0.405$ & $.109 \pm 0.365$ & $.292 \pm 0.345$ \\
\hline Uranium-235 & $.380 \pm 0.435$ & $1.13 \pm 0.5$ & $1.55 \pm 0.43$ & $.259 \pm 1.1$ \\
\hline Uranium-238 & $.158 \pm 0.19$ & $.708 \pm 0.22$ & $.594 \pm 0.19$ & $.362 \pm 0.195$ \\
\hline Zinc-65 & $-.164 \pm 0.21$ & $.433 \pm 0.21$ & $.141 \pm 0.25$ & $-.200 \pm 0.23$ \\
\hline
\end{tabular}


Table 7. Concentrations of selected isotopes from analysis by gamma spectrometry, Naval Reactors Facility and vicinity-Continued

\begin{tabular}{|c|c|c|c|c|}
\hline \multirow[b]{2}{*}{ Isotope } & \multicolumn{4}{|c|}{ Sample identifier and date sampled $(\mathrm{m} / \mathrm{d} / \mathrm{y})$} \\
\hline & $\begin{array}{l}\text { NRF-12 } \\
6 / 12 / 96\end{array}$ & $\begin{array}{l}\text { NRF-12 } \\
9 / 15 / 96\end{array}$ & $\begin{array}{l}\text { NRF-13 } \\
1 / 22 / 96\end{array}$ & $\begin{array}{l}\text { NRF-13 } \\
3 / 20 / 96\end{array}$ \\
\hline Actinium-228 & NR & NR & $1.63 \pm 0.46$ & $1.76 \pm 0.48$ \\
\hline Bismuth-214 & $1.57 \pm 0.25$ & $.787 \pm 0.22$ & $.895 \pm 0.24$ & $1.54 \pm 0.255$ \\
\hline Cesium-134 & $-.00984 \pm 0.10$ & $-.0304 \pm 0.095$ & $.0772 \pm 0.11$ & $-.0677 \pm 0.115$ \\
\hline Cesium-137 & $.115 \pm 0.11$ & $.130 \pm 0.10$ & $-.241 \pm 0.12$ & $-.0253 \pm 0.115$ \\
\hline Chromium-51 & $1.52 \pm 1.65$ & $-2.32 \pm 1.05$ & $-1.93 \pm 1.6$ & $-3.11 \pm 1.6$ \\
\hline Cobalt- 60 & $.201 \pm 0.11$ & $.386 \pm 0.10$ & $.202 \pm 0.125$ & $.250 \pm 0.135$ \\
\hline Lead-212 & $1.15 \pm 0.18$ & $.0391 \pm 0.265$ & $.0874 \pm 0.26$ & $.390 \pm 0.265$ \\
\hline Lead-214 & $.638 \pm 0.225$ & $.480 \pm 0.19$ & $.546 \pm 0.21$ & $.570 \pm 0.215$ \\
\hline Potassium-40 & $4.41 \pm 3.7$ & $.181 \pm 2.7$ & $.189 \pm 3.65$ & $56.9 \pm 3.7$ \\
\hline Radium-223 & $.299 \pm 0.55$ & $.372 \pm 0.455$ & $.116 \pm 0.5$ & $.473 \pm 0.55$ \\
\hline Radium-224 & NR & NR & $.090 \pm 0.265$ & $.727 \pm 0.16$ \\
\hline Radium-226 & $1.57 \pm 0.25$ & $.787 \pm 0.22$ & $.895 \pm 0.24$ & $1.54 \pm 0.255$ \\
\hline Radium-228 & $2.48 \pm 0.44$ & $.487 \pm 0.38$ & $1.64 \pm 0.465$ & $1.78 \pm 0.485$ \\
\hline Ruthenium-106 & $-.411 \pm 1.0$ & $0 \pm 0.9$ & $1.82 \pm 1.05$ & $-.743 \pm 1.1$ \\
\hline Thallium-208 & $.668 \pm 0.125$ & $.252 \pm 0.10$ & $.378 \pm 0.125$ & $.264 \pm 0.125$ \\
\hline Thorium-228 & $1.91 \pm 0.35$ & $1.36 \pm 0.365$ & $1.11 \pm 0.40$ & $.758 \pm 0.355$ \\
\hline Thorium-232 & NR & NR & NR & $1.20 \pm 0.7$ \\
\hline Thorium-234 & $29.6 \pm 20.5$ & $62.8 \pm 18.5$ & $-13.4 \pm 21.0$ & $28.7 \pm 20.5$ \\
\hline Uranium-234 & $.328 \pm 0.41$ & $.806 \pm 0.355$ & $.308 \pm 0.37$ & $.682 \pm 0.39$ \\
\hline Uranium-235 & $1.47 \pm 0.55$ & $.627 \pm 0.435$ & $.175 \pm 0.495$ & $1.33 \pm 0.495$ \\
\hline Uranium-238 & $.638 \pm 0.225$ & $.480 \pm 0.19$ & $.546 \pm 0.21$ & $.570 \pm 0.215$ \\
\hline Zinc-65 & $-.266 \pm 0.26$ & $-.00752 \pm 0.21$ & $-.387 \pm 0.285$ & $-.257 \pm 0.28$ \\
\hline
\end{tabular}


Table 7. Concentrations of selected isotopes from analysis by gamma spectrometry, Naval Reactors Facility and vicinity-Continued

\begin{tabular}{|c|c|c|c|c|}
\hline \multirow[b]{2}{*}{ Isotope } & \multicolumn{4}{|c|}{ Sample identifier and date sampled $(\mathbf{m} / \mathbf{d} / \mathbf{y})$} \\
\hline & $\begin{array}{l}\text { NRF-13 } \\
\text { 6/13/96 }\end{array}$ & $\begin{array}{l}\text { QAS-51 } \\
6 / 13 / 96\end{array}$ & $\begin{array}{l}\text { Z-value } \\
\text { 6/13/96 }\end{array}$ & $\begin{array}{c}\text { NRF-13 } \\
9 / 5 / 96\end{array}$ \\
\hline Actinium-228 & NR & NR & NC & NR \\
\hline Bismuth-214 & $.945 \pm 0.21$ & $.519 \pm 0.215$ & 1.42 & $.640 \pm 0.215$ \\
\hline Cesium-134 & $.0614 \pm 0.085$ & $.0792 \pm 0.095$ & .14 & $-.0664 \pm 0.10$ \\
\hline Cesium-137 & $.0443 \pm 0.095$ & $.0604 \pm 0.10$ & .12 & $-.0767 \pm 0.095$ \\
\hline Chromium-51 & $.841 \pm 1.3$ & $0 \pm 1.5$ & .42 & $-.303 \pm 0.9$ \\
\hline Cobalt- 60 & $-.0276 \pm 0.10$ & $-.00852 \pm 0.115$ & .13 & $.101 \pm 0.10$ \\
\hline Lead-212 & $.0730 \pm 0.265$ & $.453 \pm 0.145$ & 1.26 & $.775 \pm 0.15$ \\
\hline Lead-214 & $.380 \pm 0.18$ & $.523 \pm 0.195$ & .54 & $.184 \pm 0.18$ \\
\hline Potassium- 40 & $58.2 \pm 3.75$ & $11.0 \pm 2.7$ & $10.21(\mathrm{~N})$ & $23.1 \pm 2.15$ \\
\hline Radium-223 & $-.740 \pm 0.445$ & $-.0951 \pm 0.45$ & 1.02 & $.124 \pm 0.435$ \\
\hline Radium-224 & NR & NR & $\mathrm{NC}$ & NR \\
\hline Radium-226 & $.945 \pm 0.21$ & $.519 \pm 0.215$ & 1.42 & $.640 \pm 0.215$ \\
\hline Radium-228 & $1.59 \pm 0.41$ & $.612 \pm 0.375$ & 1.76 & $.136 \pm 0.42$ \\
\hline Ruthenium-106 & $.539 \pm 0.95$ & $1.67 \pm 0.95$ & .84 & $.425 \pm 0.9$ \\
\hline Thallium-208 & $.540 \pm 0.105$ & $.138 \pm 0.105$ & $2.71(\mathrm{~N})$ & $.295 \pm 0.105$ \\
\hline Thorium-228 & $.0684 \pm 0.6$ & $.398 \pm 0.30$ & .49 & $.833 \pm 0.305$ \\
\hline Thorium-232 & NR & NR & $\mathrm{NC}$ & NR \\
\hline Thorium-234 & $-16.5 \pm 18.5$ & $54.9 \pm 17.5$ & $2.80(\mathrm{~N})$ & $18.3 \pm 16.5$ \\
\hline Uranium-234 & $.686 \pm 0.325$ & $.621 \pm 0.34$ & .14 & $.430 \pm 0.32$ \\
\hline Uranium-235 & $1.27 \pm 0.425$ & $.855 \pm 0.43$ & .69 & $1.02 \pm 0.41$ \\
\hline Uranium-238 & $.380 \pm 0.18$ & $.523 \pm 0.195$ & .54 & $.184 \pm 0.18$ \\
\hline Zinc-65 & $.664 \pm 0.195$ & $-.645 \pm 0.235$ & $4.29(\mathrm{~N})$ & $.121 \pm 0.21$ \\
\hline
\end{tabular}


Table 7. Concentrations of selected isotopes from analysis by gamma spectrometry, Naval Reactors Facility and vicinity-Continued

\begin{tabular}{|c|c|c|c|c|}
\hline \multirow[b]{2}{*}{ Isotope } & \multicolumn{4}{|c|}{ Sample identifier and date sampled $(\mathrm{m} / \mathrm{d} / \mathrm{y})$} \\
\hline & $\begin{array}{c}\text { USGS-12 } \\
1 / 16 / 96\end{array}$ & $\begin{array}{c}\text { USGS-12 } \\
3 / 21 / 96\end{array}$ & $\begin{array}{c}\text { USGS-12 } \\
6 / 10 / 96\end{array}$ & $\begin{array}{l}\text { USGS-12 } \\
\text { 9/3/96 }\end{array}$ \\
\hline Actinium-228 & $1.19 \pm 0.325$ & $1.30 \pm 0.395$ & NR & NR \\
\hline Bismuth-214 & $.440 \pm 0.19$ & $.527 \pm 0.215$ & $.566 \pm 0.22$ & $.816 \pm 0.21$ \\
\hline Cesium-134 & $.0385 \pm 0.085$ & $-.00299 \pm 0.10$ & $.0277 \pm 0.095$ & $.0210 \pm 0.095$ \\
\hline Cesium-137 & $-.0435 \pm 0.095$ & $.0803 \pm 0.10$ & $.0839 \pm 0.085$ & $-.0857 \pm 0.095$ \\
\hline Chromium-51 & $.364 \pm 1.25$ & $-2.10 \pm 1.4$ & $-.594 \pm 1.4$ & $.941 \pm 1.0$ \\
\hline Cobalt- 60 & $.0329 \pm 0.095$ & $.108 \pm 0.10$ & $.0287 \pm 0.09$ & $-.00423 \pm 0.11$ \\
\hline Lead-212 & $.645 \pm 0.135$ & $1.09 \pm 0.145$ & $.597 \pm 0.325$ & $.420 \pm 0.15$ \\
\hline Lead-214 & $.446 \pm 0.16$ & $.396 \pm 0.175$ & $.306 \pm 0.185$ & $.999 \pm 0.19$ \\
\hline Potassium-40 & $37.5 \pm 2.8$ & $35.4 \pm 2.8$ & $11.8 \pm 3.3$ & $1.09 \pm 2.75$ \\
\hline Radium-223 & $.0679 \pm 0.39$ & $-.394 \pm 0.435$ & $.651 \pm 0.435$ & $.245 \pm 0.465$ \\
\hline Radium-224 & $.664 \pm 0.14$ & $1.12 \pm 0.145$ & NR & NR \\
\hline Radium-226 & $.440 \pm 0.19$ & $.527 \pm 0.215$ & $.566 \pm 0.22$ & $.816 \pm 0.21$ \\
\hline Radium-228 & $1.20 \pm 0.325$ & $1.32 \pm 0.40$ & $1.98 \pm 0.39$ & $1.02 \pm 0.40$ \\
\hline Ruthenium-106 & $.433 \pm 0.8$ & $-.831 \pm 0.95$ & $.226 \pm 0.9$ & $.514 \pm 0.9$ \\
\hline Thallium-208 & $.377 \pm 0.095$ & $.435 \pm 0.105$ & $.414 \pm 0.105$ & $.0169 \pm 0.105$ \\
\hline Thorium-228 & $1.08 \pm 0.27$ & $1.25 \pm 0.31$ & $1.19 \pm 0.305$ & $.0478 \pm 0.29$ \\
\hline Thorium-232 & $.208 \pm 0.5$ & $.803 \pm 0.55$ & NR & NR \\
\hline Thorium-234 & $37.1 \pm 15.5$ & $36.3 \pm 17.5$ & $29.7 \pm 17.5$ & $46.9 \pm 18.0$ \\
\hline Uranium-234 & $.218 \pm 0.305$ & $.100 \pm 0.325$ & $.0825 \pm 0.335$ & $.955 \pm 0.34$ \\
\hline Uranium-235 & $.583 \pm 0.375$ & $1.02 \pm 0.42$ & $.206 \pm 0.445$ & $.615 \pm 0.435$ \\
\hline Uranium-238 & $.446 \pm 0.16$ & $.396 \pm 0.175$ & $.306 \pm 0.185$ & $.999 \pm 0.19$ \\
\hline Zinc-65 & $.179 \pm 0.195$ & $-.0155 \pm 0.21$ & $-.134 \pm 0.235$ & $.320 \pm 0.195$ \\
\hline
\end{tabular}


Table 7. Concentrations of selected isotopes from analysis by gamma spectrometry, Naval Reactors Facility and vicinity-Continued

\begin{tabular}{|c|c|c|c|c|}
\hline Isotope & $\begin{array}{l}\text { USGS-97 } \\
\text { 1/17/96 }\end{array}$ & $\begin{array}{l}\text { USGS-97 } \\
3 / 25 / 96\end{array}$ & $\begin{array}{c}\text { USGS-97 } \\
6 / 11 / 96\end{array}$ & $\begin{array}{l}\text { USGS-97 } \\
9 / 4 / 96\end{array}$ \\
\hline Actinium-228 & $.318 \pm 0.36$ & $.879 \pm 0.395$ & $\mathrm{NR}$ & NR \\
\hline Bismuth-214 & $.774 \pm 0.210$ & $.542 \pm 0.215$ & $1.09 \pm 0.21$ & $.873 \pm 0.245$ \\
\hline Cesium-134 & $.0512 \pm 0.095$ & $.0883 \pm 0.105$ & $.0115 \pm 0.095$ & $-.0792 \pm 0.10$ \\
\hline Cesium-137 & $.234 \pm 0.10$ & $-.00179 \pm 0.10$ & $.331 \pm 0.095$ & $.116 \pm 0.105$ \\
\hline Chromium-51 & $2.84 \pm 1.35$ & $-.234 \pm 1.35$ & $2.54 \pm 1.35$ & $2.25 \pm 1.1$ \\
\hline Cobalt- 60 & $.0993 \pm 0.105$ & $-.0258 \pm 0.10$ & $.0808 \pm 0.11$ & $-.0249 \pm 0.11$ \\
\hline Lead-212 & $.254 \pm 0.145$ & $.290 \pm 0.27$ & $.494 \pm 0.125$ & $1.21 \pm 0.18$ \\
\hline Lead-214 & $.376 \pm 0.185$ & $.616 \pm 0.185$ & $.488 \pm 0.18$ & $.728 \pm 0.215$ \\
\hline Potassium-40 & $1.72 \pm 2.6$ & $6.17 \pm 2.95$ & $28.8 \pm 2.35$ & $46.6 \pm 3.15$ \\
\hline Radium-223 & $-.261 \pm 0.47$ & $.860 \pm 0.445$ & $.656 \pm 0.41$ & $-.436 \pm 0.5$ \\
\hline Radium-224 & $.262 \pm 0.15$ & $1.04 \pm 0.15$ & NR & NR \\
\hline Radium-226 & $.774 \pm 0.21$ & $.542 \pm 0.215$ & $1.09 \pm 0.21$ & $.873 \pm 0.245$ \\
\hline Radium-228 & $.321 \pm 0.365$ & $.888 \pm 0.40$ & $1.19 \pm 0.395$ & $1.27 \pm 0.43$ \\
\hline Ruthenium-106 & $-.596 \pm 0.95$ & $-1.50 \pm 1.0$ & $-2.76 \pm 0.9$ & $-.229 \pm 0.9$ \\
\hline Thallium-208 & $.369 \pm 0.105$ & $.462 \pm 0.115$ & $.237 \pm 0.10$ & $.662 \pm 0.115$ \\
\hline Thorium-228 & $1.06 \pm 0.295$ & $1.32 \pm 0.325$ & $.681 \pm 0.29$ & $-1.87 \pm 0.33$ \\
\hline Thorium-232 & $.260 \pm 0.6$ & $.532 \pm 0.55$ & NR & NR \\
\hline Thorium-234 & $33.7 \pm 16.5$ & $69.8 \pm 16.0$ & $54.6 \pm 17.0$ & $38.9 \pm 18.0$ \\
\hline Uranium-234 & $.501 \pm 0.34$ & $.813 \pm 0.32$ & $.504 \pm 0.315$ & $.942 \pm 0.375$ \\
\hline Uranium-235 & $.737 \pm 0.435$ & $.613 \pm 0.40$ & $1.39 \pm 0.395$ & $.736 \pm 0.5$ \\
\hline Uranium-238 & $.376 \pm 0.185$ & $.616 \pm 0.185$ & $.488 \pm 0.18$ & $.728 \pm 0.215$ \\
\hline Zinc-65 & $-.646 \pm 0.24$ & $-.380 \pm 0.23$ & $-.366 \pm 0.225$ & $-.190 \pm 0.24$ \\
\hline
\end{tabular}


Table 7. Concentrations of selected isotopes from analysis by gamma spectrometry, Naval Reactors Facility and vicinity-Continued

\begin{tabular}{|c|c|c|c|c|}
\hline \multirow[b]{2}{*}{ Isotope } & \multicolumn{4}{|c|}{ Sample identifier and date sampled $(\mathrm{m} / \mathrm{d} / \mathrm{y})$} \\
\hline & $\begin{array}{l}\text { USGS-98 } \\
1 / 17 / 96\end{array}$ & $\begin{array}{l}\text { USGS-98 } \\
3 / 21 / 96\end{array}$ & $\begin{array}{c}\text { USGS-98 } \\
6 / 11 / 96\end{array}$ & $\begin{array}{l}\text { USGS-98 } \\
9 / 4 / 96\end{array}$ \\
\hline Actinium-228 & $.222 \pm 0.36$ & $2.34 \pm 0.55$ & NR & NR \\
\hline Bismuth-214 & $.343 \pm 0.19$ & $1.08 \pm 0.29$ & $.978 \pm 0.205$ & $1.04 \pm 0.21$ \\
\hline Cesium-134 & $.0176 \pm 0.085$ & $-.00319 \pm 0.135$ & $.0615 \pm 0.85$ & $-.0923 \pm 0.095$ \\
\hline Cesium-137 & $.0369 \pm 0.09$ & $-.154 \pm 0.13$ & $-.0107 \pm 0.095$ & $.196 \pm 0.9$ \\
\hline Chromium-51 & $-.489 \pm 1.2$ & $.791 \pm 1.95$ & $-2.38 \pm 1.3$ & $.119 \pm 0.95$ \\
\hline Cobalt- 60 & $.300 \pm 0.085$ & $.102 \pm 0.155$ & $.0474 \pm 0.095$ & $.0146 \pm 0.11$ \\
\hline Lead-212 & $.150 \pm 0.23$ & $.500 \pm 0.285$ & $.788 \pm 0.145$ & $.360 \pm 0.135$ \\
\hline Lead-214 & $.0816 \pm 0.165$ & $.641 \pm 0.26$ & $.207 \pm 0.18$ & $.349 \pm 0.18$ \\
\hline Potassium- 40 & $35.5 \pm 2.65$ & $60.6 \pm 4.1$ & $55.5 \pm 3.6$ & $27.4 \pm 2.25$ \\
\hline Radium-223 & $.489 \pm 0.38$ & $.178 \pm 0.6$ & $.510 \pm 0.41$ & $.448 \pm 0.42$ \\
\hline Radium-224 & $1.23 \pm 0.14$ & $.788 \pm 0.185$ & NR & NR \\
\hline Radium-226 & $.343 \pm 0.19$ & $1.08 \pm 0.29$ & $.979 \pm 0.205$ & $1.04 \pm 0.21$ \\
\hline Radium-228 & $.112 \pm 0.36$ & $2.36 \pm 0.6$ & $1.87 \pm 0.40$ & $1.30 \pm 0.395$ \\
\hline Ruthenium-106 & $-.262 \pm 0.85$ & $.0999 \pm 1.3$ & $-1.61 \pm 0.85$ & $-1.26 \pm 0.9$ \\
\hline Thallium-208 & $.309 \pm 0.095$ & $.565 \pm 0.145$ & $.531 \pm 0.105$ & $.485 \pm 0.105$ \\
\hline Thorium-228 & $.884 \pm 0.28$ & $1.62 \pm 0.41$ & $1.52 \pm 0.30$ & $1.37 \pm 0.295$ \\
\hline Thorium-232 & $.573 \pm 0.5$ & $.612 \pm 0.8$ & NR & NR \\
\hline Thorium-234 & $26.3 \pm 15.0$ & $39.6 \pm 23.0$ & $67.0 \pm 16.5$ & $50.9 \pm 16.5$ \\
\hline Uranium-234 & $-.597 \pm 0.30$ & $.173 \pm 0.465$ & $.509 \pm 0.315$ & $.771 \pm 0.325$ \\
\hline Uranium-235 & $.0444 \pm 0.375$ & $.370 \pm 0.6$ & $.288 \pm 0.405$ & $.912 \pm 0.405$ \\
\hline Uranium-238 & $.0816 \pm 0.165$ & $.641 \pm 0.26$ & $.207 \pm 0.18$ & $.349 \pm 0.18$ \\
\hline Zinc-65 & $-.0214 \pm 0.225$ & $-.398 \pm 0.34$ & $-.229 \pm 0.22$ & $-.407 \pm 0.225$ \\
\hline
\end{tabular}


Table 7. Concentrations of selected isotopes from analysis by gamma spectrometry, Naval Reactors Facility and vicinity-Continued

\begin{tabular}{|c|c|c|c|c|}
\hline \multirow[b]{2}{*}{ Isotope } & \multicolumn{4}{|c|}{ Sample identifier and date sampled $(\mathrm{m} / \mathrm{d} / \mathrm{y})$} \\
\hline & $\begin{array}{c}\text { USGS-99 } \\
\mathbf{1 / 1 7 / 9 6}\end{array}$ & $\begin{array}{c}\text { USGS-99 } \\
3 / 25 / 96\end{array}$ & $\begin{array}{c}\text { USGS-99 } \\
6 / 11 / 96\end{array}$ & $\begin{array}{c}\text { USGS-99 } \\
9 / 4 / 96\end{array}$ \\
\hline Actinium-228 & $1.02 \pm 0.405$ & $1.55 \pm 0.37$ & NR & NR \\
\hline Bismuth-214 & $.418 \pm 0.20$ & $.518 \pm 0.195$ & $1.20 \pm 0.21$ & $.236 \pm 0.21$ \\
\hline Cesium-134 & $.0915 \pm 0.10$ & $-.0994 \pm 0.09$ & $-.0829 \pm 0.095$ & $.0189 \pm 0.095$ \\
\hline Cesium-137 & $-.0394 \pm 0.10$ & $-.226 \pm 0.10$ & $.108 \pm 0.11$ & $.119 \pm 0.095$ \\
\hline Chromium-51 & $-.961 \pm 1.45$ & $-.419 \pm 1.35$ & $-.538 \pm 1.4$ & $-.443 \pm 1.0$ \\
\hline Cobalt- 60 & $.143 \pm 0.105$ & $-.0751 \pm 0.10$ & $-.0397 \pm 0.115$ & $.230 \pm 0.095$ \\
\hline Lead-212 & $.696 \pm 0.15$ & $.0695 \pm 0.23$ & $.666 \pm 0.135$ & $.0803 \pm 0.245$ \\
\hline Lead-214 & $.229 \pm 0.18$ & $.349 \pm 0.175$ & $.378 \pm 0.185$ & $.147 \pm 0.185$ \\
\hline Potassium-40 & $1.08 \pm 2.75$ & $43.7 \pm 3.1$ & $2.14 \pm 3.65$ & $4.62 \pm 2.95$ \\
\hline Radium-223 & $-.0951 \pm 0.46$ & $.143 \pm 0.405$ & $.371 \pm 0.40$ & $-.332 \pm 0.415$ \\
\hline Radium-224 & $.718 \pm 0.155$ & $.768 \pm 0.145$ & NR & NR \\
\hline Radium-226 & $.418 \pm 0.20$ & $.518 \pm 0.195$ & $1.20 \pm 0.21$ & $.236 \pm 0.21$ \\
\hline Radium-228 & $1.03 \pm 0.41$ & $1.56 \pm 0.37$ & $1.56 \pm 0.42$ & $1.16 \pm 0.385$ \\
\hline Ruthenium-106 & $-1.04 \pm 0.9$ & $-.327 \pm 0.85$ & $.739 \pm 1.0$ & $2.36 \pm 0.85$ \\
\hline Thallium-208 & $.310 \pm 0.11$ & $.381 \pm 0.10$ & $.595 \pm 0.11$ & $.489 \pm 0.105$ \\
\hline Thorium-228 & $-.889 \pm 0.31$ & $1.09 \pm 0.29$ & $1.71 \pm 0.31$ & $1.39 \pm 0.305$ \\
\hline Thorium-232 & $1.23 \pm 0.6$ & $1.41 \pm 0.55$ & NR & NR \\
\hline Thorium-234 & $31.9 \pm 18.0$ & $9.79 \pm 17.0$ & $16.7 \pm 18.5$ & $32.9 \pm 17.0$ \\
\hline Uranium-234 & $.436 \pm 0.34$ & $.436 \pm 0.30$ & $.100 \pm 0.31$ & $.788 \pm 0.31$ \\
\hline Uranium-235 & $1.26 \pm 0.445$ & $.311 \pm 0.39$ & $1.05 \pm 0.375$ & $.781 \pm 0.43$ \\
\hline Uranium-238 & $.229 \pm 0.18$ & $.349 \pm 0.175$ & $.378 \pm 0.185$ & $.147 \pm 0.185$ \\
\hline Zinc-65 & $-.117 \pm 0.23$ & $.0431 \pm 0.21$ & $-.428 \pm 0.235$ & $-.834 \pm 0.23$ \\
\hline
\end{tabular}


Table 7. Concentrations of selected isotopes from analysis by gamma spectrometry, Naval Reactors Facility and vicinity-Continued

\begin{tabular}{|c|c|c|c|c|}
\hline \multirow[b]{2}{*}{ Isotope } & \multicolumn{4}{|c|}{ Sample identifier and date sampled $(\mathrm{m} / \mathrm{d} / \mathrm{y})$} \\
\hline & $\begin{array}{c}\text { USGS-102 } \\
1 / 18 / 96\end{array}$ & $\begin{array}{c}\text { USGS-102 } \\
3 / 19 / 96\end{array}$ & $\begin{array}{c}\text { USGS-102 } \\
6 / 11 / 96\end{array}$ & $\begin{array}{c}\text { USGS-102 } \\
9 / 14 / 96\end{array}$ \\
\hline Actinium-228 & $1.73 \pm 0.44$ & $1.09 \pm 0.365$ & NR & NR \\
\hline Bismuth-214 & $.762 \pm 0.24$ & $1.29 \pm 0.21$ & $1.58 \pm 0.235$ & $.884 \pm 0.21$ \\
\hline Cesium-134 & $-.0458 \pm 0.11$ & $-.0439 \pm 0.09$ & $-.106 \pm 0.095$ & $-.136 \pm 0.095$ \\
\hline Cesium-137 & $-.00327 \pm 0.115$ & $-.0205 \pm 0.10$ & $-.0329 \pm 0.105$ & $.182 \pm 0.10$ \\
\hline Chromium-51 & $.378 \pm 1.55$ & $-3.81 \pm 1.4$ & $1.71 \pm 1.7$ & $-1.45 \pm 1.0$ \\
\hline Cobalt- 60 & $.119 \pm 0.11$ & $.0697 \pm 0.105$ & $.00836 \pm 0.115$ & $-.0254 \pm 0.12$ \\
\hline Lead-212 & $.238 \pm 0.28$ & $.727 \pm 0.135$ & $.389 \pm 0.36$ & $.0347 \pm 0.295$ \\
\hline Lead-214 & $.800 \pm 0.205$ & $.526 \pm 0.185$ & $.706 \pm 0.23$ & $.480 \pm 0.195$ \\
\hline Potassium-40 & $52.4 \pm 3.5$ & $.102 \pm 3.15$ & $8.12 \pm 3.65$ & $1.14 \pm 2.5$ \\
\hline Radium-223 & $-.0946 \pm 0.5$ & $.138 \pm 0.435$ & $.750 \pm 0.50$ & $.404 \pm 0.475$ \\
\hline Radium-224 & $.245 \pm 0.29$ & $.749 \pm 0.14$ & $.401 \pm 0.375$ & NR \\
\hline Radium-226 & $.762 \pm 0.24$ & $1.29 \pm 0.21$ & $1.58 \pm 0.235$ & $.884 \pm 0.21$ \\
\hline Radium-228 & $1.75 \pm 0.445$ & $1.10 \pm 0.37$ & $3.16 \pm 0.43$ & $1.00 \pm 0.375$ \\
\hline Ruthenium-106 & $-.677 \pm 1.05$ & $-.658 \pm 0.95$ & $-2.47 \pm 1.00$ & $1.07 \pm 0.85$ \\
\hline Thallium-208 & $.319 \pm 0.115$ & $.248 \pm 0.105$ & $.839 \pm 0.155$ & $.189 \pm 0.105$ \\
\hline Thorium-228 & $1.56 \pm 0.5$ & $.711 \pm 0.30$ & $2.41 \pm 0.44$ & $.534 \pm 0.30$ \\
\hline Thorium-232 & $.818 \pm 0.65$ & $.689 \pm 0.55$ & NR & NR \\
\hline Thorium-234 & $23.7 \pm 21.0$ & $-1.72 \pm 17.5$ & $54.4 \pm 19.0$ & $62.0 \pm 18.5$ \\
\hline Uranium-234 & $.643 \pm 0.36$ & $.689 \pm 0.32$ & $1.14 \pm 0.395$ & $-.203 \pm 0.34$ \\
\hline Uranium-235 & $-.217 \pm 0.47$ & $.746 \pm 0.40$ & $1.33 \pm 0.55$ & $.366 \pm 0.425$ \\
\hline Uranium-238 & $.800 \pm 0.205$ & $.526 \pm 0.185$ & $.706 \pm 0.23$ & $.480 \pm 0.195$ \\
\hline Zinc-65 & $-.538 \pm 0.295$ & $-.287 \pm 0.23$ & $-.0153 \pm 0.23$ & $.163 \pm 0.125$ \\
\hline
\end{tabular}


Table 8. Regulatory volatile organic compounds for which round-four water samples were analyzed, and measured concentrations, expected concentrations, and percent recoveries for $Q A S-47$

[Analyses were performed by the U.S. Geological Survey National Water Quality Laboratory using U.S. Environmental Protection Agency method 524.2. Analytical results and expected concentrations are in micrograms per liter $(\mu \mathrm{g} / \mathrm{L})$. The laboratory reporting levels in $\mu \mathrm{g} / \mathrm{L}$ are from Timme (1995, p. 49).

Concentrations of all listed compounds were less than the laboratory reporting levels, except for those listed in table 10 and those listed for QAS-47. The quality-assurance spiked organic sample (QAS-47) was prepared on January 23, 1996. Symbols: <, less than; NIS, compound was not contained in the spiking solution; NA, calculating a percent recovery value was not appropriate]

\begin{tabular}{|c|c|c|c|c|}
\hline Compound & $\begin{array}{c}\text { Reporting } \\
\text { level }\end{array}$ & $\begin{array}{c}\text { Measured } \\
\text { concentration, } \\
\text { QAS-47 }\end{array}$ & $\begin{array}{c}\text { Expected } \\
\text { concentration, } \\
\text { QAS-47 }\end{array}$ & $\begin{array}{l}\text { Percent } \\
\text { recovery, } \\
\text { QAS-47 }\end{array}$ \\
\hline Dichlorodifluoromethane & 0.2 & $<0.2$ & NIS & $\overline{\mathrm{NA}}$ \\
\hline Vinyl chloride & .2 & .3 & 1.75 & 20 \\
\hline Trichlorofluoromethane & .2 & $<.2$ & NIS & NA \\
\hline 1,1-Dichloroethene & .2 & .5 & 1.25 & 41 \\
\hline Methylene chloride & .2 & 1.3 & NIS & NA \\
\hline Trans-1,2-dichloroethene & .2 & $<.2$ & NIS & NA \\
\hline 1,1-Dichloroethane & .2 & $<.2$ & NIS & NA \\
\hline Cis-1,2-dichloroethene & .2 & $<.2$ & NIS & NA \\
\hline Chloroform & .2 & $<.2$ & NIS & NA \\
\hline 1,1,1-Trichloroethane & .2 & .8 & 1.25 & 65 \\
\hline Carbon tetrachloride & .2 & .8 & 1.25 & 62 \\
\hline Benzene & .2 & $<.2$ & NIS & NA \\
\hline 1,2-Dichloroethane & .2 & 1.2 & 1.50 & 79 \\
\hline Trichloroethene & .2 & 1.0 & 1.25 & 76 \\
\hline 1,2-Dichloropropane & .2 & $<.2$ & NIS & NA \\
\hline Bromodichloromethane & .2 & 1.2 & 1.50 & 80 \\
\hline Toluene & .2 & $<.2$ & NIS & NA \\
\hline Tetrachloroethene & .2 & .9 & 1.25 & 68 \\
\hline Dibromochloromethane & .2 & 1.3 & 1.75 & 75 \\
\hline Chlorobenzene & .2 & $<.2$ & NIS & NA \\
\hline Ethylbenzene & .2 & 1.3 & 1.50 & 84 \\
\hline Xylenes (total) & .2 & $<.2$ & NIS & NA \\
\hline Styrene & .2 & $<.2$ & NIS & NA \\
\hline Bromoform & .2 & 1.3 & 1.75 & 74 \\
\hline 1,3-Dichlorobenzene (meta) & .2 & $<.2$ & NIS & NA \\
\hline 1,4-Dichlorobenzene (para) & .2 & 1.5 & 1.50 & 97 \\
\hline 1,2-Dichlorobenzene (ortho) & .2 & $<.2$ & NIS & NA \\
\hline Trichlorotrifluoroethane & .2 & $<.2$ & NIS & NA \\
\hline MTBE & .2 & 1.3 & 1.75 & 75 \\
\hline 1,1,2,2-Tetrachloroethane & .2 & $<.2$ & NIS & NA \\
\hline
\end{tabular}


Table 9. Base/neutral organic compounds for which round-four water samples were analyzed, and measured concentrations, expected concentrations, and percent recoveries for QAS-47

[Analyses were performed by the U.S. Geological Survey National Water Quality Laboratory using gas chromatography to separate the compounds and mass spectrometry for identification and quantification. Initial extraction was with methylene chloride. Analytical results and expected concentrations are in micrograms per liter $(\mu \mathrm{g} / \mathrm{L})$. Laboratory reporting levels are in $\mu \mathrm{g} / \mathrm{L}$ (Timme, 1995, p. 58). Concentrations of all listed compounds were less than the laboratory reporting levels, except those listed in table 10 and those listed for QAS-47. The qualityassurance spiked organic sample (QAS-47) was prepared on January 23, 1996. Symbols: <, less than; NIS, compound was not contained in the spiking solution; NA, calculating a percent recovery was not appropriate]

\begin{tabular}{|c|c|c|c|c|}
\hline Compound & $\begin{array}{c}\text { Reporting } \\
\text { level }\end{array}$ & $\begin{array}{c}\text { Measured } \\
\text { concentration, } \\
\text { QAS-47 }\end{array}$ & $\begin{array}{c}\text { Expected } \\
\text { concentration, } \\
\text { QAS-47 }\end{array}$ & $\begin{array}{l}\text { Percent } \\
\text { recovery, } \\
\text { QAS-47 }\end{array}$ \\
\hline Acenaphthylene & 5 & 16 & 20 & 79 \\
\hline Acenaphthene & 5 & 14 & 20 & 71 \\
\hline Anthracene & 5 & 20 & 20 & 101 \\
\hline Benzo (b) fluoranthene & 10 & 17 & 20 & 84 \\
\hline Benzo (k) fluoranthene & 10 & 20 & 20 & 100 \\
\hline Benzo (a) pyrene & 0.5 & 20 & NIS & NA \\
\hline Bis (2-chloroethyl) ether & 5 & 14 & 20 & 71 \\
\hline Bis (2-chloroethoxy) methane & 5 & 15 & 20 & 73 \\
\hline Bis (2-chloroisopropyl) ether & 5 & 12 & 20 & 62 \\
\hline Butylbenzylphthalate & 5 & 12 & 20 & 58 \\
\hline Chrysene & 0.5 & 21 & 20 & 104 \\
\hline Diethyl phthalate & 5 & $<5$ & 20 & 25 \\
\hline Dimethyl phthalate & 5 & $<5$ & 20 & 9 \\
\hline Fluoranthene & 5 & 22 & 20 & 109 \\
\hline Fluorene & 5 & 18 & 20 & 91 \\
\hline Hexachlorocyclopentadiene & 5 & 9 & 20 & 46 \\
\hline Hexachloroethane & 5 & 13 & 20 & 67 \\
\hline Indeno $(1,2,3-c, d)$ pyrene & 10 & 20 & 20 & 98 \\
\hline Isophorone & 5 & $<5$ & 20 & 17 \\
\hline N-Nitrosodi-n-propylamine & 5 & 9 & 20 & 47 \\
\hline N-Nitrosodiphenylamine & 5 & 41 & 20 & 203 \\
\hline N-Nitrosodimethylamine & 5 & 6 & 20 & 29 \\
\hline Nitrobenzene & 5 & 15 & 20 & 77 \\
\hline Phenanthrene & 5 & 17 & 20 & 85 \\
\hline Pyrene & 5 & 23 & 20 & 114 \\
\hline Benzo $(g, h, i)$ perylene & 10 & 19 & 20 & 97 \\
\hline Benz (a) anthracene & 0.5 & 20 & 20 & 98 \\
\hline Benzene, 1,2,-dichloro- & 5 & 13 & 20 & 65 \\
\hline Benzene, 1,2,4-trichloro- & 5 & 14 & 20 & 72 \\
\hline 1,2,5,6-Dibenz $(\mathrm{a}, \mathrm{h})$ anthracene & 10 & 20 & 20 & 100 \\
\hline Benzene, 1,3-dichloro- & 5 & 13 & 20 & 65 \\
\hline Benzene, 1,4-dichloro- & 5 & 13 & 20 & 65 \\
\hline Naphthalene, 2-chloro- & 5 & 16 & 20 & 78 \\
\hline Di-n-octylphthalate & 10 & 18 & 20 & 91 \\
\hline Toluene, 2,4-dinitro- & 5 & 14 & 20 & 72 \\
\hline Toluene, 2,6-dinitro- & 5 & 15 & 20 & 77 \\
\hline
\end{tabular}


Table 9-Base/neutral organic compounds for which round-four water samples were analyzed and measured concentrations, expected concentrations, and percent recoveries for QAS-47-Continued

\begin{tabular}{lcccc}
\hline \multicolumn{1}{c}{ Compound } & $\begin{array}{c}\text { Reporting } \\
\text { level }\end{array}$ & $\begin{array}{c}\text { Measured } \\
\text { concentration, } \\
\text { QAS-47 }\end{array}$ & $\begin{array}{c}\text { Expected } \\
\text { concentration, } \\
\text { QAS-47 }\end{array}$ & $\begin{array}{c}\text { Percent } \\
\text { recovery, } \\
\text { QAS-47 }\end{array}$ \\
\hline Phenylphenylether, 4-bromo- & 5 & 16 & NIS & NA \\
Phenylphenylether, 4-chloro & 5 & 19 & 20 & 94 \\
Naphthalene & 5 & 16 & 20 & 78 \\
Bis (2-ethylhexyl) phthalate & 5 & 19 & 20 & 93 \\
Di-n-butylphthalate & 5 & 12 & 20 & 59 \\
Hexachlorobenzene & 5 & 21 & 20 & 106 \\
Hexachlorobutadiene & 5 & 15 & 20 & 77 \\
\hline
\end{tabular}




\section{Table 10. Concentrations of regulatory volatile organic compounds and base/neutral}

organic compounds in water from round-four samples

[Analyses were performed by the U.S. Geological Survey National Water Quality Laboratory. Analytical results are in micrograms per liter. No entry for a sample listed in table 2 indicates that concentrations of compounds listed in tables 8 and 9 were less than their respective reporting levels. Sample identifier: see figure 2 for location of wells. Date sampled: $\mathrm{m} / \mathrm{d} / \mathrm{y}$, month/day/year. QAS indicates quality-assurance sample; the Z-value associated with the replicate sample (QAS-51) was calculated using equation 1. Remarks: E, indicates concentration was estimated by laboratory analyst]

\begin{tabular}{lllll}
\hline Sample identifier & $\begin{array}{c}\text { Date sampled } \\
(\mathbf{m} / \mathbf{d} / \mathbf{y})\end{array}$ & Compound & Concentration & Remarks \\
\hline
\end{tabular}

[Regulatory volatile organic compounds]

\begin{tabular}{|c|c|c|c|c|}
\hline \multirow[t]{8}{*}{ NRF-6 } & $1 / 16 / 96$ & Chloroform & 0.4 & \\
\hline & & Tetrachloroethene & .5 & $\mathrm{E}$ \\
\hline & $3 / 19 / 96$ & Chloroform & .4 & \\
\hline & & Tetrachloroethene & .6 & \\
\hline & $6 / 10 / 96$ & Chloroform & .4 & \\
\hline & & Tetrachloroethene & .5 & \\
\hline & $6 / 10 / 96$ & Chloroform & .4 & \\
\hline & & Tetrachloroethene & .5 & \\
\hline \multirow[t]{3}{*}{ NRF-13 } & $1 / 22 / 96$ & Methylene chloride & .7 & \\
\hline & $3 / 20 / 96$ & Methylene chloride & .8 & \\
\hline & $6 / 13 / 96$ & Methylene chloride & .5 & \\
\hline QAS-51 & $6 / 13 / 96$ & Methylene chloride & .5 & Replicate, $\mathrm{Z}$-value $=0.00$ \\
\hline NRF-13 & $9 / 11 / 96$ & Methylene chloride & .3 & \\
\hline
\end{tabular}

[Base/nuetral organic compounds]

$\begin{array}{lclrr}\text { QAS-52 } & 9 / 3 / 96 & \text { Bis (2-ethylhexyl) phthalate } & 6 & \text { Field blank } \\ \text { USGS } 99 & 6 / 11 / 96 & \text { Diethyl phthalate } & 6 & \\ \text { USGS } 102 & 6 / 11 / 96 & \text { Di-n-butylphthalate } & 57\end{array}$

